






\title{
BASELINE RISK ASSESSMENT FOR GROUNDWATER CONTAMINATION AT THE URANIUM MILL TAILINGS SITE NEAR MONUMENT VALLEY, ARIZ̄ONA
}

\section{Draft}

\section{September 1993}

\author{
Prepared for \\ U.S. Department of Energy \\ UMTRA Project Office \\ Albuquerque, New Mexico \\ Prepared by \\ Jacobs Engineering Group Inc. \\ Albuquerque, New Mexico
}

\section{DISCLAIMER}

This report was prepared as an account of work sponsored by an agency of the United States Government. Neither the United States Gnvernment nor any agency thereof, nor any of their makes any warranty, express or implied, or assumes any legal liability or responsibility for the accuracy, completeness, or usefulness of any information, apparatus, product, or bility for the accuracy, compesents that its use would not infringe privately owned rights. Referprocess disclosed, or represents that its use would process, or service by trade name, trademark, ence herein to any specific commercial product, process, or serice by its endorsement, recommanufacturer, or otherwise does not necessarily constitute or iny agency thereof. The views mendation, or favoring by the United States Government or any agencessarily state or reflect those of the and opinions of authors expressed herein do 


\section{CITIZENS' SUMMARY}

This baseline risk assessment evaluates potential impact to public health or the environment resulting from groundwater contamination at the former uranium mill processing site near Monument Valley, Arizona. The tailings and other contaminated material at this site are being relocated and stabilized in a disposal cell at Mexican Hat, Utah, through the U.S. Department of Energy (DOE) Uranium Mill Tailings Remedial Action (UMTRA) Project. The tailings removal is planned for completion by spring 1994. After the tailings are removed, groundwater contamination at the site will continue to be evaluated. This risk assessment is the first document specific to this site for the Groundwater Project. It will be used to assist in determining what remedial action is needed for contaminated groundwater at the site.

Currently, no domestic or drinking water wells exist in the contaminated groundwater. Because no one is drinking the affected water and there is no surface expression of the contaminated groundwater, there are no current health or environmental risks associated with the contaminated groundwater. However, because groundwater contamination extends nearly 1 mile from the former processing site and groundwater in the vicinity is used for drinking water, this risk assessment evaluates potential future use of the contaminated groundwater.

This risk assessment follows the basic approach outlined by the U.S. Environmental Protection Agency. The first step is to evaluate groundwater data collected from monitor wells at the site over the last five years. Evaluation of those data show that the main contaminants associated with the site are nitrate, sulfate, strontium, vanadium, and uranium. Of these, only nitrate, sulfate, and uranium are potentially toxic to humans at the concentrations found at or near the site.

The next step in the risk assessment is to estimate how much of these contaminants people would be exposed to if a drinking well were installed in the contaminated groundwater. Because the contaminant concentrations vary each time a well is sampled and because people vary in how much they weigh and drink, this risk assessment uses probability distributions to determine how much of each contaminant would likely be ingested if people had a well available at the site. The probability distributions describe how likely it is for something to happen. For example, based on population survey data, probability distributions can describe what percentage of people drink a half gallon of water each day and what percentage drink only one cup of water each day.

These estimated amounts of contaminants that could be ingested in drinking water are then compared to the potential toxic effects of these contaminant levels. Nitrate is the most significant hazard in the groundwater at the Monument Valley mill site. Nitrate is of primary concern for infants because at current levels it will interfere with their ability to carry oxygen in the blood. This toxic effect only occurs in infants because infants absorb nitrate from the stomach differently than adults. The nitrate level in groundwater as far as 0.5 mile downgradient of the the mill site exceeds the level that has been reported elsewhere to be lethal when ingested by infants. For this reason, the DOE is working with 
the Navajo Nation to restrict access to contaminated groundwater until the site can be further evaluated.

Other contaminants that occur at toxic levels are sulfate and uranium. Sulfate concentrations near the site could cause severe diarrhea that could be particularly dangerous in infants. Uranium concentrations at the site are associated with a potentially increased risk of cancer. The additional lifetime cancer risk from ingesting contaminated groundwater would be 7 in 100,000, on average. The amounts of vanadium and strontium that could be ingested are much lower than any level associated with a toxic effect.

This risk assessment also evaluates potential effects on livestock, if the groundwater were used to water cattle or sheep. These animals are sensitive to nitrate toxicity. The nitrate concentrations in groundwater up to 1000 feet to the northeast (downgradient) of the former mill site are high enough to kill these animals if they drink the contaminated groundwater.

Based on current understanding of groundwater conditions, flow direction, and flow rate, no surface expressions (for example seeps) of the contaminated groundwater now occur. Therefore, at this time wild or domestic animals cannot come into direct contact with contaminated groundwater. However, plants may take up contaminants in groundwater, and then be eaten by wild or domestic animals. Without additional data, it is difficult to evaluate whether this pathway represents an ecological concern. However, no ecological threat exists to the plants themselves, either irrigated or having roots in contact with the most contaminated groundwater.

Livestock currently drink water from the frog ponds east of the site. These ponds are fted from a portion of the unconsolidated aquifer that is not affected by the contaminant plume. An assessment of the water quality in these ponds indicates that no adverse effects to livestock or vegetation would result from exposure to this water.

The potential exists for future surface expression of contaminated groundwater as the contaminant plume moves to the northeast. Currently, the plume does not extend far enough for this to occur. Increased monitoring in the area of potential surface expressions is being considered to determine if and when such expressions could occur and what contaminant concentrations would be at that point.

Monitor wells are sampled routinely as part of the Monument Valley remedial action (the relocation of tailings to Mexican Hat). The Monument Valley site will be further evaluated during the groundwater activities of the UMTRA Project. This evaluation is underway and includes further characterization of the groundwater and its movement. Based on these results and this risk assessment, an approach will be developed to address contaminated groundwater. This approach will be presented in an environmental assessment that will include public and tribal government involvement. In the interim, access to contaminated groundwater will be controlled. 


\section{TABLE OF CONTENTS}

Section Page

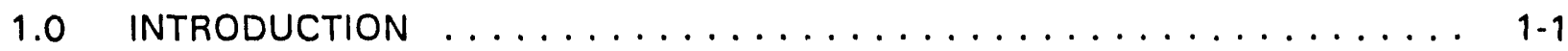

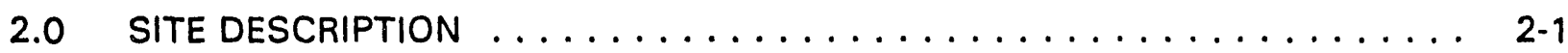

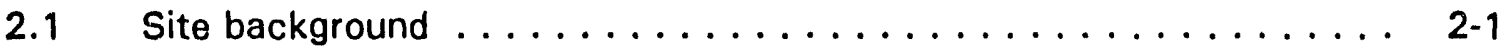

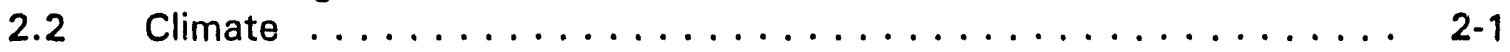

2.3 Hydrogeology .......................... 24

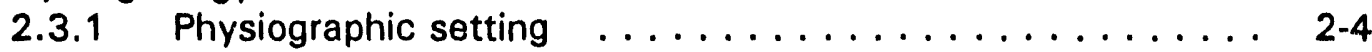

2.3.2 Stratigraphy ...................... 2-4

2.3.3 Presence and movement of groundwater . . . . . . . . . 2-8

2.3.4 Surface water regime ................. 2-13

2.4 Land use ............................. 2-13

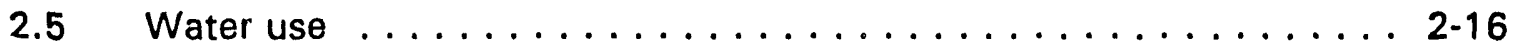

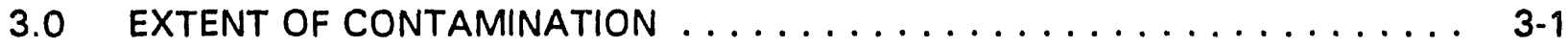

3.1 Background water quality data summary . . . . . . . . . . . . 3-1

3.2 Magnitude of site-related groundwater contamination . . . . . . . . 3-1

3.3 Contaminants of concern ..................... 3-14

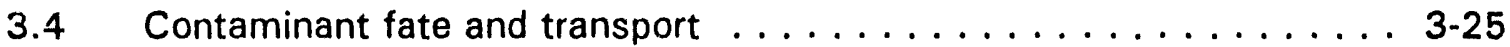

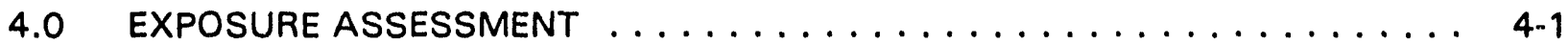

4.1 Potentially exposed population . . . . . . . . . . . . . 4 4-1

4.2 Exposure pathways ....................... 4 4-1

4.2.1 Drinking water ingestion ............... 4-3

4.2.2 Dermal absorption ................... 4-3

4.2.3 Ingestion of groundwater-irrigated produce ......... 4-3

4.2.4 Ingestion of meat or milk from groundwater-fed livestock . . 4-6

4.3 Exposure concentrations .................... 4-6



4.5 Exposure assessment uncertainties . . . . . . . . . . . 4-15

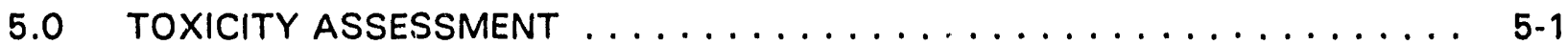

5.1 Contaminant toxicity summaries . . . . . . . . . . . . . . 5-1

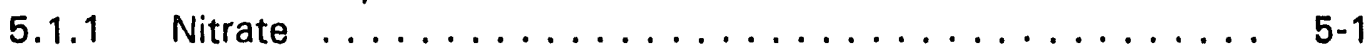

5.1 .2 Strontium .................... 5-3



5.1 .4 Uranium ....................... 5-8

5.1 .5 Vanadium ...................... 5-12

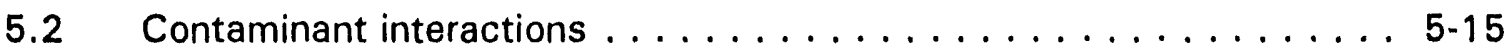

5.3 Contaminant risk factors ................... 5-17



6.1 Potential noncarcinogenic health effects ............. 6-1

6.2 Potential carcinogenic health effects . . . . . . . . . . . . 6-4 
TABLE OF CONTENTS (Concluded)

Section

Page



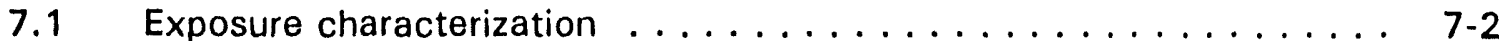

7.2 Ecological receptors .................... $7-3$

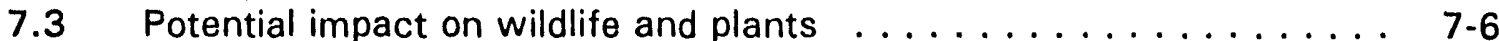

7.4 Potential impact to livestock .................... 7-9

7.5 Summary ....................... $7-11$

8.0 INTERPRETATION AND RECOMMENDATIONS $\ldots \ldots \ldots \ldots \ldots \ldots \ldots$



8.2 Groundwater criteria . . . . . . . . . . . . . . . . $8-1$

8.3 Risk mitigation measures . . . . . . . . . . . . . . . . $8-3$

8.4 Future site activities $\ldots \ldots \ldots \ldots \ldots \ldots \ldots \ldots \ldots \ldots \ldots$

8.5 Recommendations $\ldots \ldots \ldots \ldots \ldots \ldots \ldots \ldots \ldots \ldots$

9.0 LIST OF CONTRIBUTORS $\ldots \ldots \ldots \ldots \ldots \ldots \ldots \ldots \ldots \ldots \ldots$






\section{LIST OF FIGURES}

\section{Figure}

Page

2.1 Location of the Monument Valley site $\ldots \ldots \ldots \ldots \ldots \ldots \ldots$

Location of upper and lower tailings piles, residences, domestic wells, and seeps - Monument Valley, Arizona, site . . . . . . . . . . . . . . .

2.3 Topographic map showing locations of the monitor wells and geologic cross section - Monument Valley, Arizona, site . . . . . . . . . . . . . .

2.4 View to the northwest showing lower tailings pile, lined evaporation pond, buff-colored Shinarump Conglomerate, and pink DeChelly Sandstone ..... . 2-6

2.5 Outcrop west of tailings piles showing Shinarump Conglomerate, Moenkopi Formation, and DeChelly Sandstone . . . . . . . . . . . . . . . . 2-6

2.6 Geologic cross section $X-X^{\prime}-$ Monument Valley, Arizona, site . . . . . . . 2-7

2.7 Water table contours in unconsolidated aquifer - Monument Valley, Arizona, site . . . . . . . . . . . . . . . . . . . . . . 2-9

2.8 Potentiometric surface for the Shinarump Conglomerate - Monument Valley, Arizona, site . . . . . . . . . . . . . . . . . . . . . . 2-11

2.9 Potentiometric surface for the DeChelly Sandstone - Monument Valley, Arizona, site ... . . . . . . . . . . . . . . . . . . . . 2-12

2.10 Surface water regime illustrating ephemeral drainage channels -

Monument Valley, Arizona, site . . . . . . . . . . . . . . . . . . . . . . 2-14

2.11 View to the southeast showing location of spring at arrow by light green tree ............................... 2-15

2.12 View to north down Cane Valley showing excavated ponds fed by spring water ...............................

3.1 Sulfate plume isopleths - Monument Valley, Arizona, site . . . . . . . . . . .

3.2 Chloride:sulfate ratios in background wells in the unconsolidated aquifer - Monument Valley, Arizona, site . . . . . . . . . . . . . . . . .

3.3 Chloride:sulfate ratios in background wells $(602,603)$ and plume wells $(606,653,655,656,662,669)$ in the unconsolidated aquifer-Monument Valley, Arizona, site . . . . . . . . . . . . . . . . . . . . . .

3.4 Chloride:sulfate ratios in the unconsolidated aquifer, comparison between 605 , background wells, and contaminated well 653 - Monument Valley,

Arizona, site . . . . . . . . . . . . . . . . . . . . . . . .

3.5 Chloride:sulfate ratios for Shinarump and DeChelly wells: background $(601,613,615)$ and downgradient $(614,657,659$, 663) - Monument Valley, Arizona, site . . . . . . . . . . . . . . . . . . . .

3.6 Box plots illustrating nitrate concentrations in downgradient and background wells with increasing depth of aquifer - Monument Valley, Arizona, site . . . 3-10

3.7 Box plots illustrating uranium concentrations in downgradient and background wells with increasing depth of aquifer - Monument Valley,

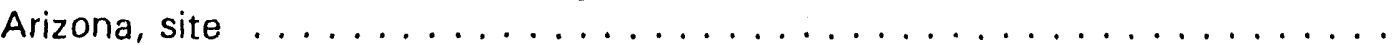

3.8 Box plots illustrating strontium concentrations in downgradient and background wells with increasing depth of aquifer - Monument Valley, Arizona, site 


\section{LIST OF FIGURES (Continued)}

Fiqure

Page

3.9 Box plots illustrating sulfate concentrations in downgradient and background wells with increasing depth of aquifer - Monument

Valley, Arizona, site . . . . . . . . . . . . . . . . . . . . . . .

3.10 Nitrate plume in unconsolidated groundwater-Monument Valley, Arizona, site ........................... 3-15

4.1 Conceptual model, Monument Valley, Arizona, site $\ldots \ldots \ldots \ldots$. . . . . . 4-2

4.2 Simulated distribution of nitrate based on data from well 606 -

Monument Valley, Arizona, site . . . . . . . . . . . . . . . . . . 4 4-3

4.3 Simulated distribution of sulfate based on data from well 655 .

Monument Valley, Arizona, site . . . . . . . . . . . . . . . . . . 4-8

4.4 Simulated distribution of strontium based on data from well 655 -

Monument Valley, Arizona, site . . . . . . . . . . . . . . . . . . . 4-9

4.5 Simulated distribution of uranium based on data from well 655 -

Monument Valley, Arizona, site . . . . . . . . . . . . . . . . . . 4-10

4.6 Simulated distribution of vanadium based on data from well 655 -

Monument Valley, Arizona, site . . . . . . . . . . . . . . . . . . 4-11

4.7 Probability distributions for tap water ingestion rates by age groups . . . . . 4-13

4.8 Probability distributions for body weight by age group . . . . . . . . . . 4-14

4.9 Comparison of distributions of potential sulfate exposures as a result of drinking contaminated groundwater for the three age groups examined -

Monument Valley, Arizona, site . . . . . . . . . . . . . . . 4-16

4.10 Distribution of potential nitrate exposures for infants consuming contaminated groundwater - Monument Valley, Arizona, site . . . . . . . . 4-17

4.11 Distribution of potential strontium exposures for children as a result of contaminated groundwater ingestion - Monument Valley, Arizona, site . . . . 4-18

4.12 Distribution of potential uranium exposures for children as a result of contaminated groundwater ingestion - Monument Valley, Arizona, site . . . 4 4-19

4.13 Distribution of potential vanadium exposures for children as a result of contaminated groundwater ingestion - Monument Valley, Arizona, site . . . 4.20



5.2 Strontium toxicity ranges $\ldots \ldots \ldots \ldots \ldots \ldots \ldots$

5.3 Sulfate toxicity ranges . . . . . . . . . . . . . . . . . 5-9

5.4 Half-lives and radiation emission patterns resulting from decay of

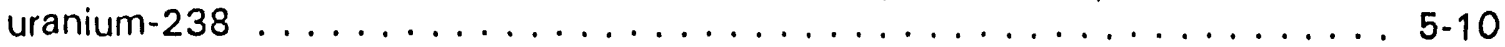

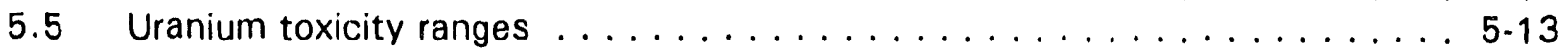

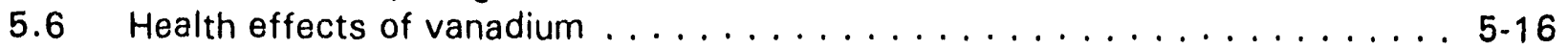

6.1 Health effects of predicted nitrate exposure ranges for infants -

Monument Valley, Arizona, site . . . . . . . . . . . . . . . . . . 6 6-2

6.2 Health effects of predicted sulfate exposure ranges for children -
Monument Valley, Arizona, site $\ldots \ldots \ldots \ldots \ldots \ldots \ldots \ldots \ldots \ldots \ldots \ldots$ 


\section{LIST OF FIGURES (Continued)}

Figure

\section{Page}

6.3 Health effects of predicted strontium exposure ranges for children -

Monument Valley, Arizona, site . . . . . . . . . . . . . . . . . . 6-5

6.4 Health effects of predicted vanadium exposure ranges for children -

Monument Valley, Arizona, site . . . . . . . . . . . . . . . . . 6-6

6.5 Health effects of predicted uranium exposure ranges for children -

Monument Valley. Arizona, site . . . . . . . . . . . . . . . . . . . 6-7

6.6 Increased lifetime cancer risk associated with predicted radiation

exposures resulting from ingestion of uranium in groundwater - Monument

Valley, Arizona, site . . . . . . . . . . . . . . . . . . . 


\section{LIST OF TABLES}

Table

3.1 Ground water monitor well network at tailings sites . . . . . . . . . 3-2

3.2 Statistical summary of groundwater quality in the unconsolidated



3.3 Statistical summary of groundwater quality in the Shinarump Conglomerate at Monument Valley, 1988-1993 . . . . . . . . . . . . . . 3-21

3.4 Contaminants of potential concern for human health evaluation . . . . . . . 3-24

3.5 Monument Valley speciation summary . . . . . . . . . . . . . . . . . 3-26

4.1 Exposure dose calculations and equation definitions for groundwater usage in future hypothetical adult scenarios, Monument Valley UMTRA Project site, Monument Valley, Arizona . . . . . . . . . . . . . . . . 4 4-4

4.2 Exposure dose ca!culations and equation definitions for groundwater-irrigated produce ingestion in future hypothetical adult scenarios, Monument Valley UMTRA Project site, Monument Valley, Arizona ............................. 4 4-5



5.2 Toxicity values: carcinogenic effects . . . . . . . . . . . . . 5-18

7.1 Comparison of contaminants of concern in frog pond water with available water quality criteria . . . . . . . . . . . . . . . 7-5

7.2 Comparison of estimated plant concentrations to phytotoxic concentrations .......................... 7-8

7.3 Comparison of contaminants of concern in groundwater with available water quality criteria $\ldots \ldots \ldots \ldots \ldots \ldots \ldots \ldots \ldots \ldots$. . . . . . . . . . . . .

8.1 Concentration limits of constituents $\ldots \ldots \ldots \ldots \ldots \ldots \ldots$ 


\section{LIST OF ACRONYMS AND ABBREVIATIONS}

\begin{tabular}{|c|c|}
\hline Acronym & Definition \\
\hline ac & acre \\
\hline$A C L$ & alternate concentration limit \\
\hline$B \mid A$ & Bureau of Indian Affairs \\
\hline $\mathrm{cm}$ & centimeter \\
\hline DOE & U.S. Department of Energy \\
\hline EPA & U.S. Environmental Protection Agency \\
\hline $\mathrm{ft}$ & foot, feet \\
\hline FWOC & Federal water quality criteria \\
\hline FWS & Fish and Wildlife Service \\
\hline $\mathbf{g}$ & gram \\
\hline ha & hectare \\
\hline $\begin{array}{l}\text { HEAST } \\
\text { hr }\end{array}$ & $\begin{array}{l}\text { Health Effects Assessment Summary Tables } \\
\text { hour }\end{array}$ \\
\hline IHS & Indian Health Service \\
\hline in & inch \\
\hline IRIS & Integrated Risk Information System \\
\hline $\mathrm{km}$ & kilometer \\
\hline $\mathrm{LD}_{50}$ & $\begin{array}{l}\text { lethal oral dose at which } 50 \text { percent of the exposed animals will } \\
\text { die }\end{array}$ \\
\hline$\mu g / k g$ & micrograms per kilogram \\
\hline MCL & maximum concentration limit \\
\hline $\mathrm{mg} / \mathrm{kg} / \mathrm{day}$ & amount of substance in $\mathrm{mg}$ taken in per $\mathrm{kg}$ body weight per day \\
\hline $\mathrm{mg} / \mathrm{L}$ & milligrams per liter \\
\hline mi & mile \\
\hline $\mathrm{mV}$ & millivolts \\
\hline $\mathrm{ng} / \mathrm{mL}$ & nanograms per milliliter \\
\hline $\mathrm{pCi} / \mathrm{L}$ & picocuries per liter \\
\hline PL & Public Law \\
\hline $\operatorname{RfD}$ & reference dose \\
\hline TDS & total dissolved solids \\
\hline UCL & upper confidence limit \\
\hline UMTRA & Uranium Mill Tailings Remedial Action \\
\hline UMTRCA & Uranium Mill Tailings Radiation Control Act \\
\hline USGS & U.S. Geological Service \\
\hline & cubic yards \\
\hline$y r$ & year \\
\hline
\end{tabular}




\subsection{INTRODUCTION}

The purpose of this baseline risk assessment is to determine whether the groundwater contamination at the Monument Valley, Arizona, uranium mill tailings site has the potential to adversely affect public health or the environment. The Monument Valley site is one of 24 abandoned uranium mill tailings sites that are undergoing remediation in accordance with the requirements of the Uranium Mill Tailings Radiation Control Act (UMTRCA) of 1978 [Public Law (PL) 95-604] under the oversight of the U.S. Department of Energy (DOE).

The first phase of the Uranium Mill Tailings Remedial Action (UMTRA) Project at Monument Valley is designed to stabilize the tailings in a disposal cell that minimizes 1) radon and other radiation emissions and 2) further contamination of groundwater. The tailings and other contaminated materials will be transported 17 miles (mi) 127 kilometers $(\mathrm{km})]$ north to the Mexican Hat, Utah, disposal cell for stabilization. Movement of the tailings is in progress and should be completed by spring 1994.

Next, groundwater contamination will be evaluated to determine if any remedial action is necessary and to implement such action. The DOE was authorized to perform groundwater restoration in the 1988 amendments to UMTRCA.

The evaluation strategy and remediation methodology for contaminated groundwater at the UMTRA sites will be described in "Programmatic Environmental Impact Statement for Groundwater Contamination at the UMTRA Sites" (DOE, n.d.), currently in preparation. This baseline risk assessment is one of 24 site-specific documents prepared to evaluate potential health and environmental risks and provide information to assist in determining what remedial action is necessary. Based on the Programmatic Environmental Impact Statement, additional groundwater characterization, and this risk assessment, a site-specific environmental assessment will be prepared to evaluate and select remedial action for the Monument Valley site.

This first assessment of groundwater-related risks is based on available groundwater data. Where this data base is insufficient to adequately evaluate risks, critical data gaps will be identified. Because for most UMTRA sites this is the first look at risks from site-related contamination of groundwater, only the major exposure pathways are evaluated here. If future decisions or actions at this site cause the primary pathway to change, other pathways will be evaluated in more detail at that time. This document will be updated following completion of the site characterization phase of the project.

This risk assessment follows the basic approach prescribed by the U.S. Environmental Protection Agency (EPA) for evaluating hazardous waste sites for potential health and environmental impacts resulting from groundwater contamination at the Monument Valley site. The baseline risk assessment will include the following steps:

- Data evaluation.

- Combining existing data from various site investigations. 
- Comparing sample results with background and tailings source data.

- Selecting chemical data for use in the risk assessment.

- Exposure assessment.

- Characterizing exposure setting.

- Identifying exposure pathways.

- Quantifying exposure.

- Toxicity assessment.

- Identifying toxicity values.

- Evaluating noncarcinogenic effects.

- Evaluating carcinogenic effects from radionuclides and chemical carcinogens.

- Public health risk characterization.

- Comparing toxicity ranges to predicted exposure ranges.

- Combining risks across exposure pathways and multiple contaminants.

- Characterizing uncertainties.

- Environmental risk.

- Characterizing potential biota exposure pathways.

- Identifying potential ecological receptors.

- Evaluating environmental risk qualitatively.

These steps are used to estimate risks from current and potential future use of groundwater. 


\subsection{SITE DESCRIPTION}

The Monument Valley site is located on the Navajo Reservation in northern Arizona, $13 \mathrm{mi}$ $(22 \mathrm{~km})$ east of the Monument Valley Navajo Tribal Park in a remote area near Cane Valley (Figure 2.1). The site is located on Bureau of Indian Affairs (B|A) Navajo Service Road 6440,17 road $\mathrm{mi}(27 \mathrm{~km})$ south of the Mexican Hat disposal site. Two uranium mill tailings piles were at the base of Yazzie Mesa at an elevation of approximately 4900 feet (ft) [1500 meters (m)] above mean sea level (Figure 2.2).

The tailings piles are currently being moved to the Mexican Hat disposal cell as part of the surface remediation at the site. The upper tailings pile was in an ephemeral drainage channel that flows into Cane Valley; the pile covered approximately 11 acres (ac) [4 hectare (ha)] and had a mean thickness of $11 \mathrm{ft}(3 \mathrm{~m})$. The lower pile covered 17 ac $(7 \mathrm{ha})$ with an average thickness of $24 \mathrm{ft}(7 \mathrm{~m})$. Total volume of tailings in the two piles was approximately 842,600 cubic yards $\left(y d^{3}\right)\left[644,300\right.$ cubic meters $\left.\left(\mathrm{m}^{3}\right)\right]$. As a result of milling operations, an additional $55 \mathrm{ac}(22 \mathrm{ha})$ at the site showed surface contamination. These areas include an evaporation pond, an ore storage/mill yard, a batch leach yard, and areas contaminated by windblown tailings. Several year-round residences are within $0.5 \mathrm{mi}(0.8 \mathrm{~km})$ of the site. At least three points of surface-water expression (seeps) have been identified in the valley.

\section{$2.1 \quad$ SITE BACKGROUND}

The mill at Monument Valley operated from the summer of 1955 to 1968. From 1955 until 1964, the site consisted of an upgrader plant which produced a slime concentrate that was trucked to mills in Durango, Colorado, and Shiprock, New Mexico, leaving behind sand tailings which form the majority of the lower tailings pile. In 1964, the upgrader was replaced by a concentrator and batch leach facility. Sand tailings were leached in a batch process with sulfuric acid. Low grade ores were heap-leached with sulfuric acid in the region of the upper tailings pile. The acid-leach solutions from both operations were neutralized to $\mathrm{pH} 4$ with ammonia and then to $\mathrm{pH} 7$ with lime.

\subsection{CLIMATE}

The climate in the area of the Monument Valley tailings is arid with less than 6 inches (in) [15 centimeters $(\mathrm{cm})]$ annual precipitation relatively evenly distributed throughout the year, although somewhat greater during the July through October thunderstorm period characteristic of the Colorado plateau. Snowfall statistics are not available for Monument Valley, but Mexican Hat, 17 road $\mathrm{mi}(27 \mathrm{~km})$ north, had an annual average of $3.3 \mathrm{in}(8.4 \mathrm{~cm})$ for the 20-year (yr) period ending in 1980 (Stevens et al., 1983).

Temperatures can show considerable variation within 24-hour (hr) periods and across seasons. Winters are cold with temperatures below freezing from November through March. Summers are hot with highs from the 90 s to the low 100 s degrees Fahrenheit (32 to 38 degrees Celsius). 


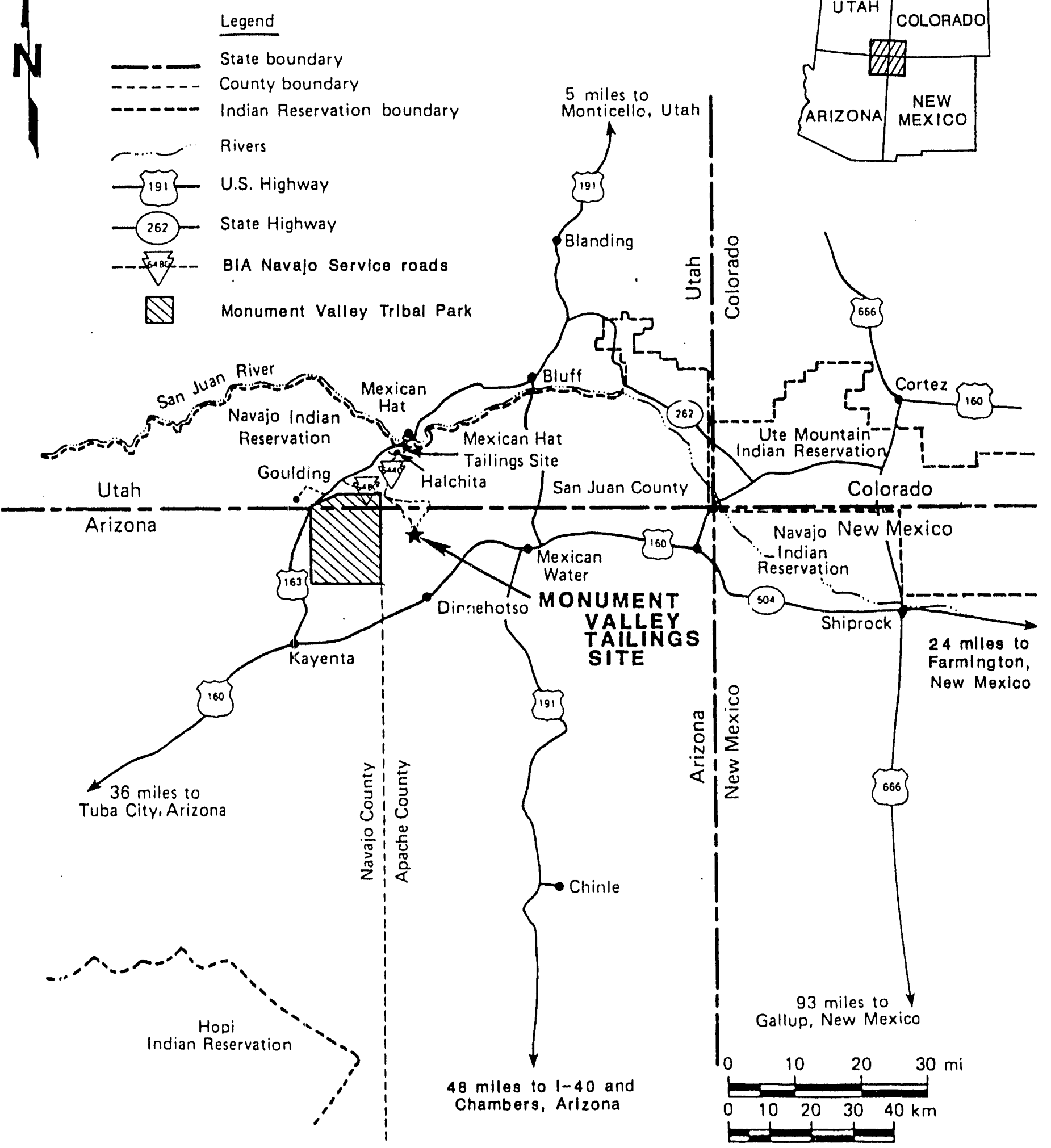

FIGURE 2.1

LOCATION OF THE MONUMENT VALLEY SITE 


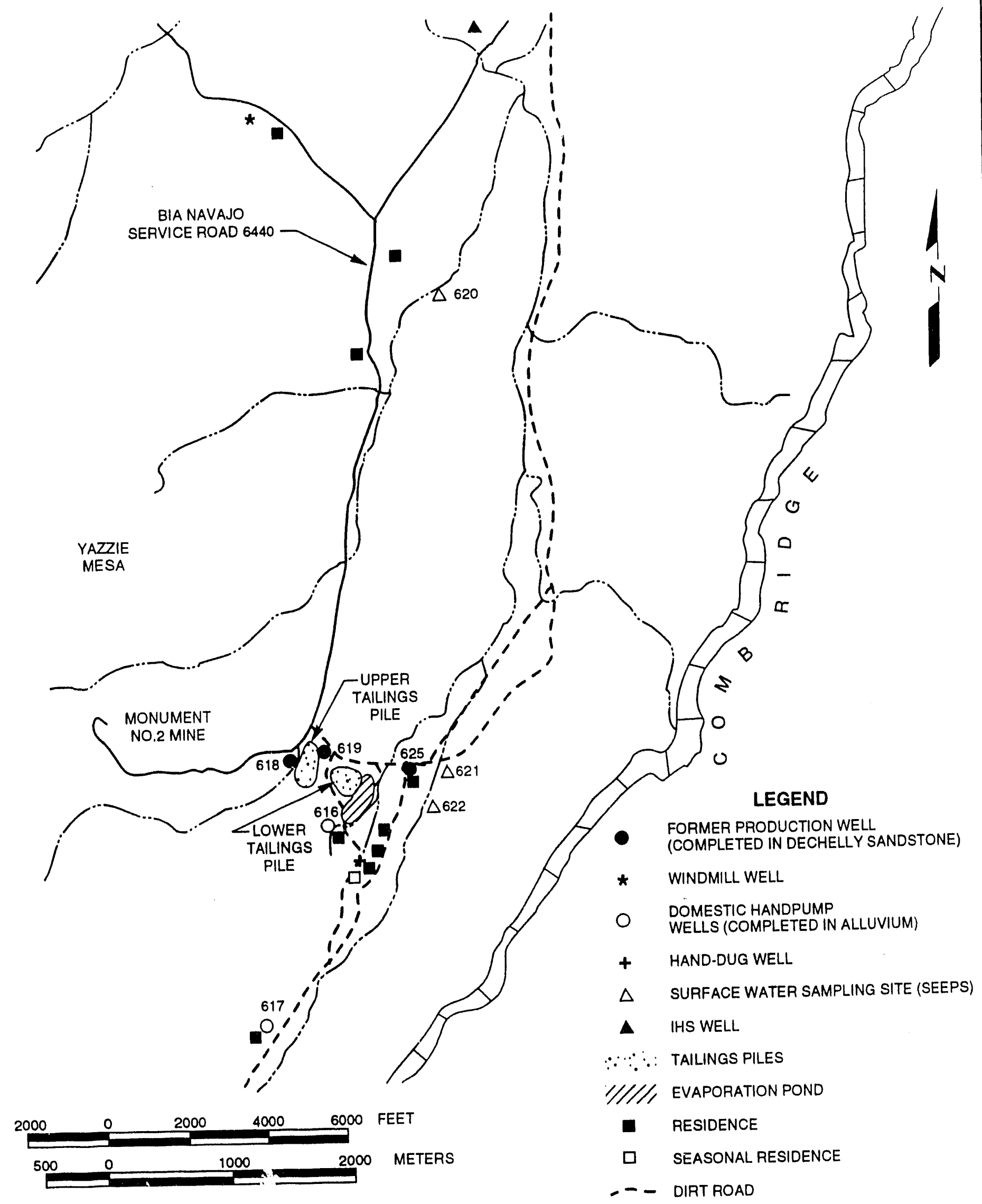

FIGURE 2.2

LOCATION OF UPPER AND LOWER TAILINGS PILES, RESIDENCES, DOMESTIC WELLS, AND SEEPS - MONUMENT VALLEY, ARIZONA, SITE 


\section{HYDROGEOLOGY}

\subsubsection{Physiographic setting}

The tailings site is located on the west side of Cane Valley, a northward draining strike valley eroded into the Chinle Formation. The valley floor elevation is approximately $4800 \mathrm{ft}(1500 \mathrm{~m})$ along Cane Valley Wash east of the tailings pile (Figure 2.3). Figure 2.3 also shows the locations of the wells discussed in this report. The valley is bordered on the east by Comb Ridge (Figure 2.2), a $600-\mathrm{ft}$ $(200-\mathrm{m})$ high escarpment of Navajo, Kayenta, and Wingate Sandstones. On the west side of the valley (where the tailings were located), the bedrock, which dips to the east at approximately 5 degrees, rises up to Yazzie Mesa at an elevation of over $5300 \mathrm{ft}(1600 \mathrm{~m})$ (Figures 2.4 and 2.5). The valley between these bedrock outcrops is filled with wind-blown (eolian) sand and some transported gravel and rock fragments (unconsolidated aquifer).

\subsubsection{Stratigraphy}

The major hydrostratigraphic formations of concern underlying the Monument Valley UMTRA site are, in descending order, the unconsolidated eolian and alluvial deposits (hereafter referred to as the unconsolidated aquifer), the Shinarump Member of the Chinle Formation (called the Shinarump Conglomerate), the Moenkopi Formation, and the DeChelly Sandstone of the Cutler Formation (Witkind and Thaden, 1963). Figure 2.5 shows the Shinarump Conglomerate, the Moenkopi Formation, and the DeChelly Sandstone in an outcrop on the eastern flank of Yazzie Mesa west of the tailings pile. Figure 2.6 depicts a cross section beneath the site at the location identified in Figure 2.3.

The dune sands are well sorted, wind-blown deposits of fine-to medium-grained sands. The unconsolidated aquifer includes sands and gravels and transported fragments of bedrock. This unconsolidated aquifer is more than $80 \mathrm{ft}(24 \mathrm{~m})$ thick in the center of Cane Valley and feathers out on the dipping bedrock along the western side of the valley. The western side of the lower tailings pile rests on the bedrock whiie the eastern side of the pile is on more than $50 \mathrm{ft}(15 \mathrm{~m})$ of unconsolidated aquifer as shown on the cross section in Figure 2.6.

The Shinarump Conglomerate consists of lenticular, cross-bedded formations of sandstone and conglomerate with occasional thin mudstone layers. It ranges in thickness from 20 to $85 \mathrm{ft}(6$ to $26 \mathrm{~m})$ in the vicinity of the site. The Shinarump Conglomerate directly underlies the upper tailings pile and occurs below the unconsolidated aquifer under the lower tailings pile.

The Moenkopi Formation, a shaley siltstone and sandstone, underlies the Shinarump Conglomerate. It is 50 to $60 \mathrm{ft}(15$ to $20 \mathrm{~m})$ thick beneath most of site, but thins to the west and is only about $20 \mathrm{ft}(6 \mathrm{~m})$ thick beneath the upper pile. The Moenkopi Formation acts as an aquitard between the Shinarump Conglomerate and the underlying DeChelly Sandstone Member of the Cutler Formation. 


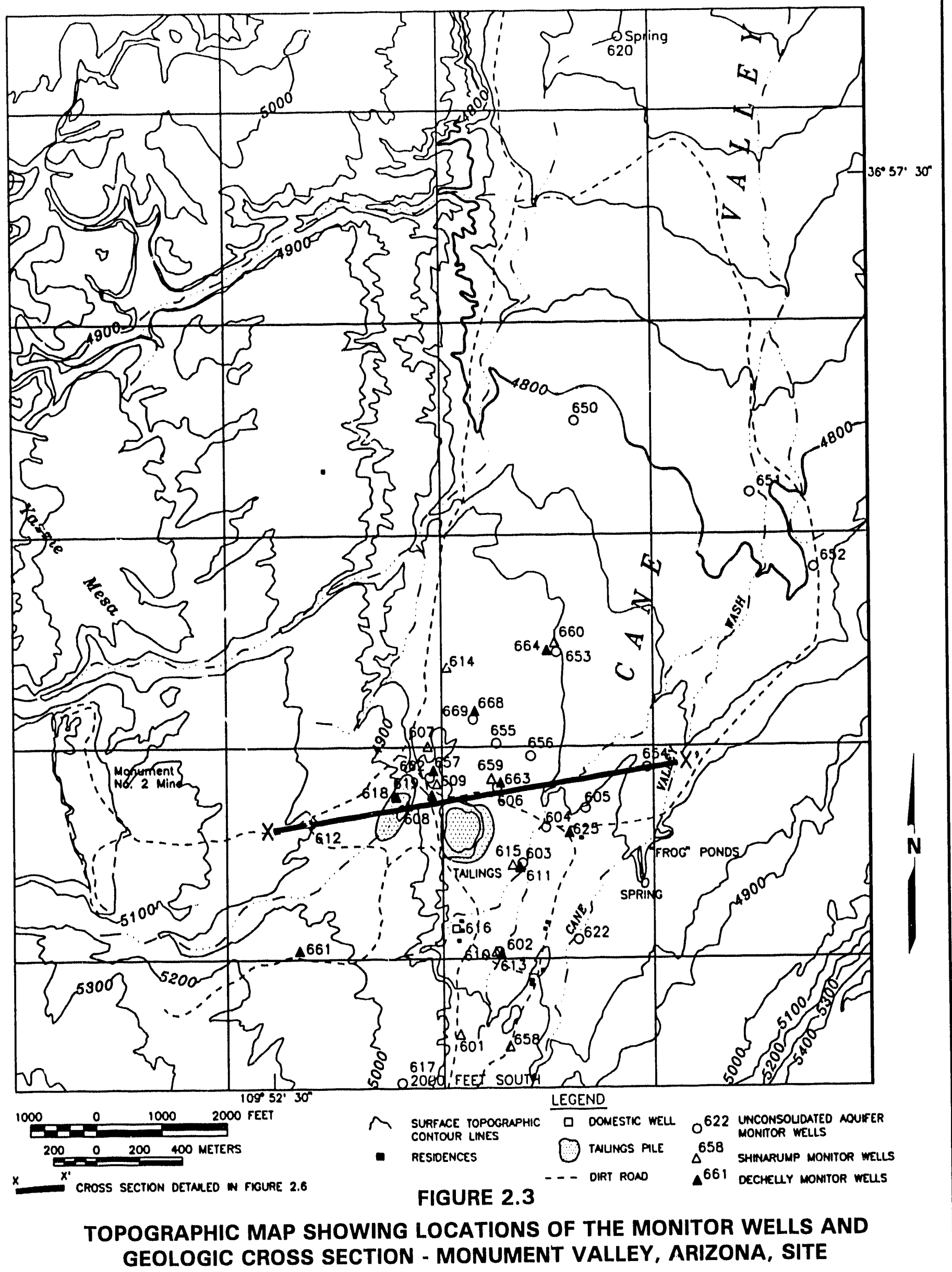




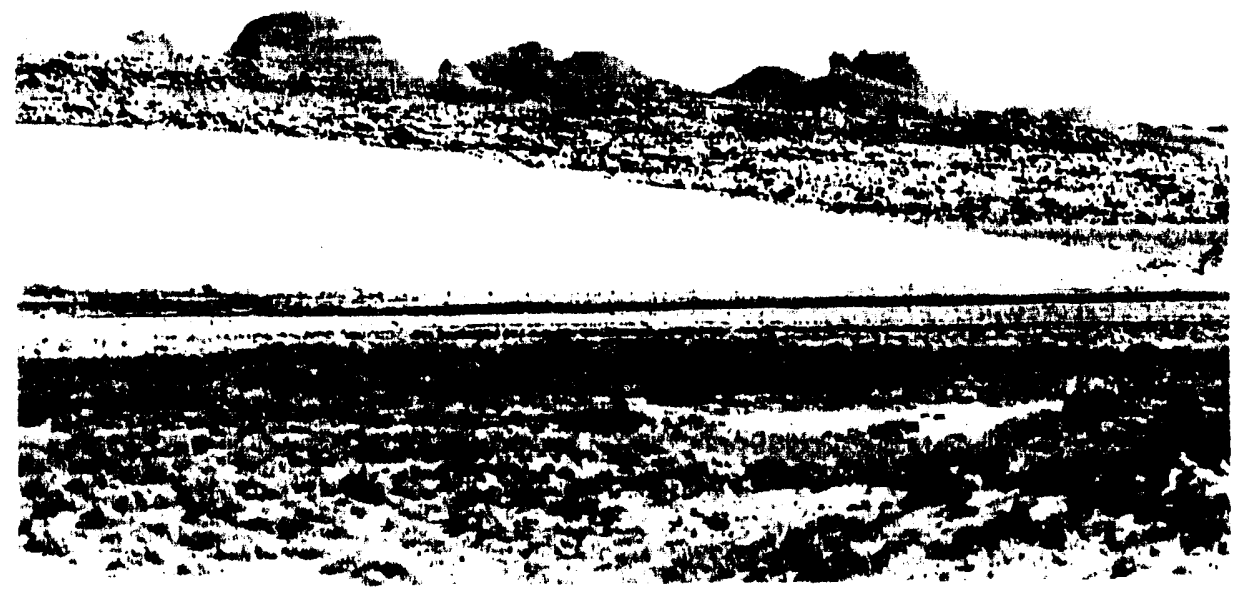

FIGURE 2.4

VIEW TO NORTHWEST SHOWING LOWER TAILINGS PILE, LINED EVAPORATION POND, BUFF-COLORED SHINARUMP CONGLOMERATE AND PINK DECHELLY SANDSTONE (TELEPHOTO SHOT AT 150X)

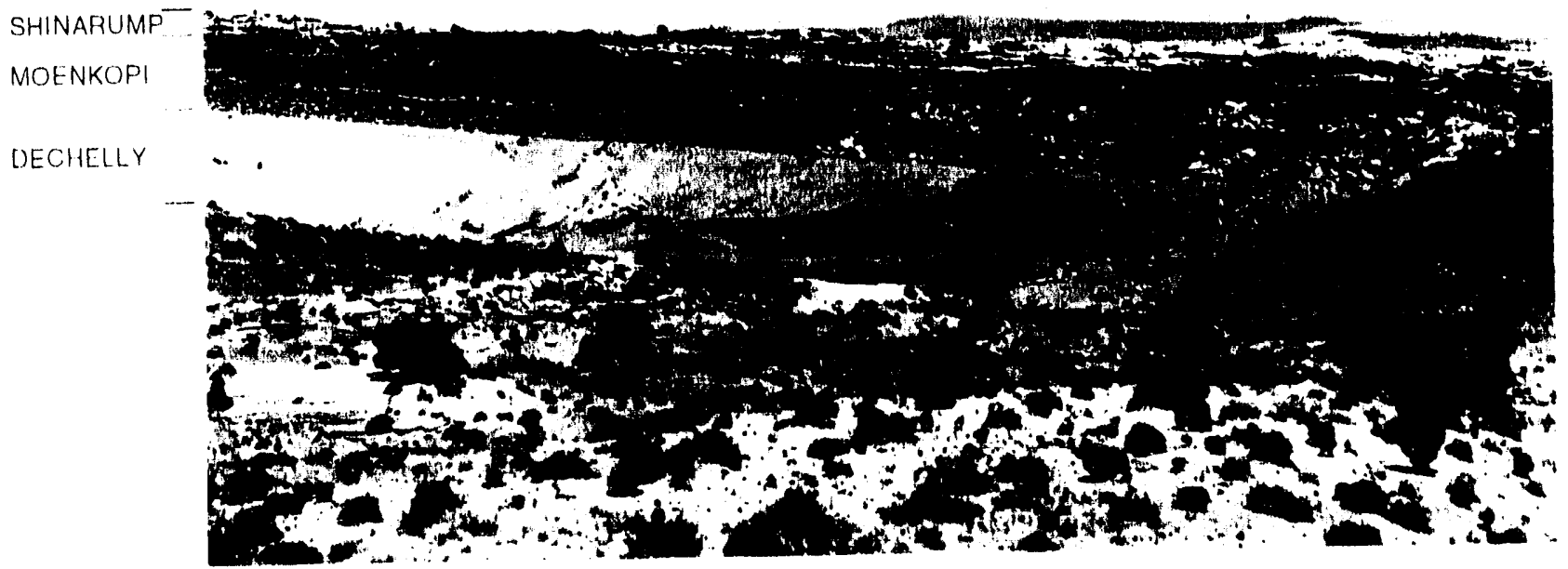

FIGURE 2.5

OUTCROP WEST OF TAILINGS PILES SHOWING SHINARUMP CONGLOMERATE, MOENKOPI FORMATION, AND DECHELLY SANDSTONE 


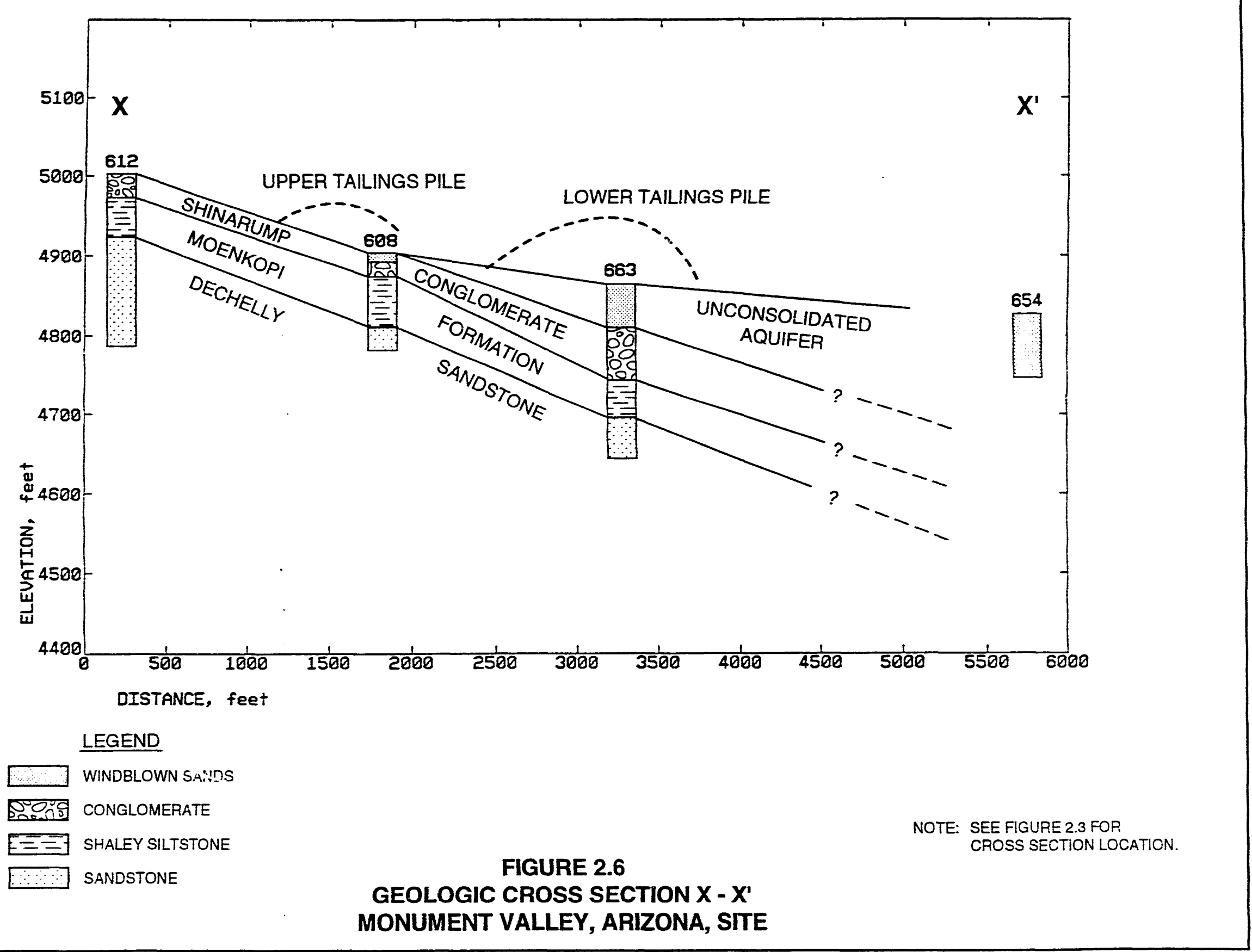


The DeChelly Sandstone is a massive, cross-bedded, fine-grained sandstone, approximately $500 \mathrm{ft}(150 \mathrm{~m})$ thick beneath the site. It is the lowest aquifer beneath the Monument Valley tailings site and is underlain by the low permeability Organ Rock Shale.

\section{$2 \quad 2.3 .3 \quad$ Presence and movement of groundwater}

\section{Unconsolidated aquifer}

Groundwater within the unconsolidated aquifer is unconfined. Depths to groundwater range from the land surface near Cane Valley Wash to slightly more than $10 \mathrm{ft}(3 \mathrm{~m})$ below the lower tailings pile. This unconfined groundwater is recharged by underflow from upgradient and by precipitation. Some leakage may also occur upwards from the deeper confined portions of the Shinarump Conglomerate and DeChelly Sandstone through the confining beds. Some recharge to the unconsolidated aquifer is also provided by discharges from artesian monitor wells 611, 613, and 615 and former production well 625 completed in the DeChelly Sandstone.

East of the tailings area and on the opposite side of Cane Valley Wash, as shown on Figure 2.3, a spring-fed pond may also provide recharge to the unconsolidated aquifer in the lower part of the valley.

A water table contour map for the unconsolidated aquifer is also shown in Figure 2.7. Groundwater in the area of the site flows to the north-northeast under an average hydraulic gradient of 0.01 . This water moves down the valley as underflow, with some discharging to Cane Valley Wash.

The piezometric head in one of the monitor wells that is screened in the unconsolidated aquifer, well 654, is approximately $1 \mathrm{ft}(0.3 \mathrm{~m})$ above land surface, even though the ground around the well is dry (Figure 2.6). This elevated water level indicates that the well screen at 34 to $58 \mathrm{ft}(10$ to $18 \mathrm{~m})$ below land surface has encountered water with a higher piezometric head than the water table. In an unconfined aquifer, this occurrence means the groundwater flow lines are curved upwards. At this location, the groundwater is rising to join the surface flow in Sane Valley Vash.

The same groundwater flow pattern is anticipated on the eastern side of Cane Valley Wash and is probably the source of the spring mentioned above. These opposing flow regimes will prevent water on one side of the valley from crossing to the opposite side. The water elevation from well 654 is not included in the water table contour map because it is not thought to be representative of the shallow water table flow regime.

The hydraulic conductivity computed from aquifer pumping test data resulted in a value of $19 \mathrm{ft} /$ day [6 meters per day (m/day)]. The linear ground water velocity in the unconsolidated aquifer was calculated using a hydraulic gradient of 0.01 and an assumed effective porosity of 0.25 . Groundwater velocity in the 


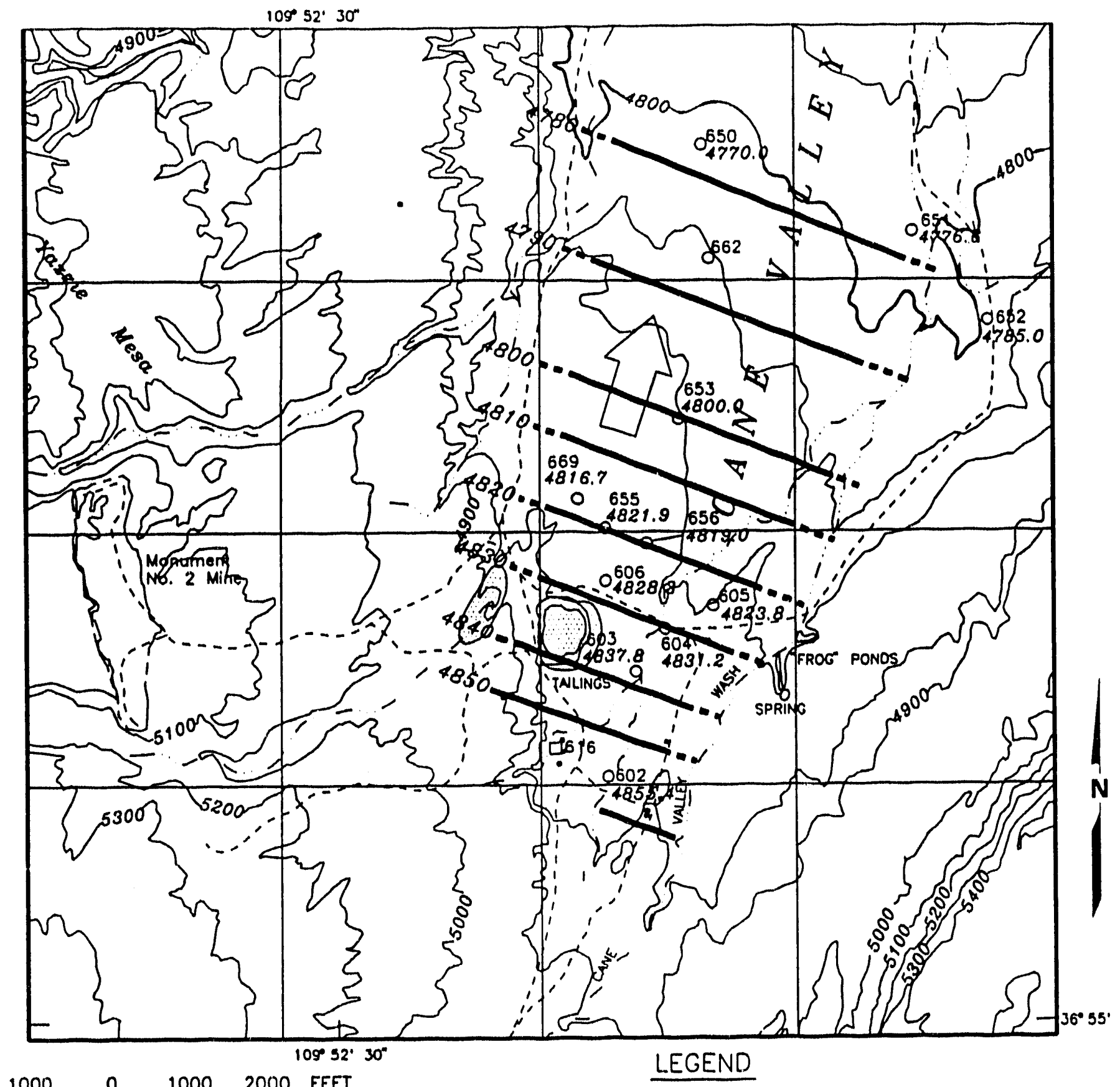

$1000 \quad 0 \quad 1000 \quad 2000$ FEET

$200 \quad 0 \quad 200 \quad 400$ METERS

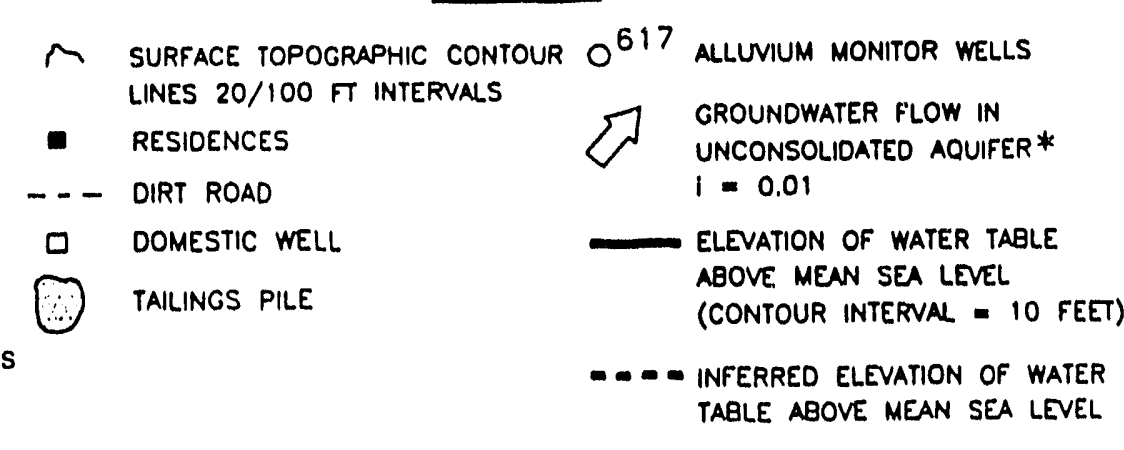

BASED ON AVERAGE STATIC WATER LEVELS

BETWEEN 3/85 AND 2/93. AVERAGE

VARIATION DURING PERIOD: $0.8^{\prime}$

MAXIMUM VARIATION IN ANY WELL: 1.3

* based on 3 - PT. Solution Using Well.s 604,605, AND 606

FIGURE 2.7

WATER TABLE CONTOURS IN UNCONSOLIDATED

AQUIFER - MONUMENT VALLEY, ARIZONA, SITE 
unconsolidated aquifer is approximately $300 \mathrm{ft} / \mathrm{yr}(90 \mathrm{~m} / \mathrm{yr}$ ). (All calculations are included in Appendix $F$ of the Monument Valley and Mexican Hat remedial action plan (DOE, 1993).]

\section{Shinarump Conglomerate}

Groundwater within the Shinarump Conglomerate occurs under both unconfined and confined conditions. Water entering the Shinarump through outcrops along the western side of the valley will be unconfined and move downdip to the east. Where this water moves beneath the sandstone layers, it may become confined. The infiltrating water joins other groundwater that is moving from farther south or that may have leaked from the DeChelly Sandstone below the Moenkopi Formation.

Water level measurements at the site indicate the groundwater moves to the north under approximately the same average hydraulic gradient $(0.01)$ as in the unconsolidated aquifer. A potentiometric surface map for the Shinarump Conglomerate is shown in Figure 2.8.

Hydraulic conductivities computed from four slug tests in the Shinarump Conglomerate varied from 0.4 to $8 \mathrm{ft} /$ day $(0.1$ to $2 \mathrm{~m} /$ day $)$. The groundwater velocities were calculated using a hydraulic gradient of 0.01 and an assumed effective porosity of 0.1 . The range of linear velocities for groundwater flow is from 15 to $300 \mathrm{ft} / \mathrm{yr}(5$ to $90 \mathrm{~m} / \mathrm{yr}$ ).

\section{DeChelly Sandstone}

Groundwater within the DeChelly Sandstone is generally confined by the overlying Moenkopi Formation. This confined groundwater flows northward from recharge areas to the south and west. The groundwater in the DeChelly Sandstone also flows under an average hydraulic gradient of approximately 0.01 to the north-northeast. A potentiometric surface map for the DeChelly Sanustone is presented in Figure 2.9.

The hydraulic conductivity computed from an aquifer pumping test in the DeChelly Sandstone was $6 \mathrm{ft} /$ day $(2 \mathrm{~m} /$ day $)$. Using a hydraulic gradient of 0.01 and an assumed effective porosity of 0.11 , the average linear groundwater velocity is $200 \mathrm{ft} / \mathrm{yr}(60 \mathrm{~m} / \mathrm{yr}$ ) (DOE, 1993).

\section{Vertical gradients}

An upward, vertical hydraulic gradient exists between the DeChelly Sandstone and the overlying aquifers. In some cases, there is also evidence of an upward gradient between the Shinarump and the overlying unconsolidated aquifer. This is supported by Figures 2.7, 2.8, and 2.9. 

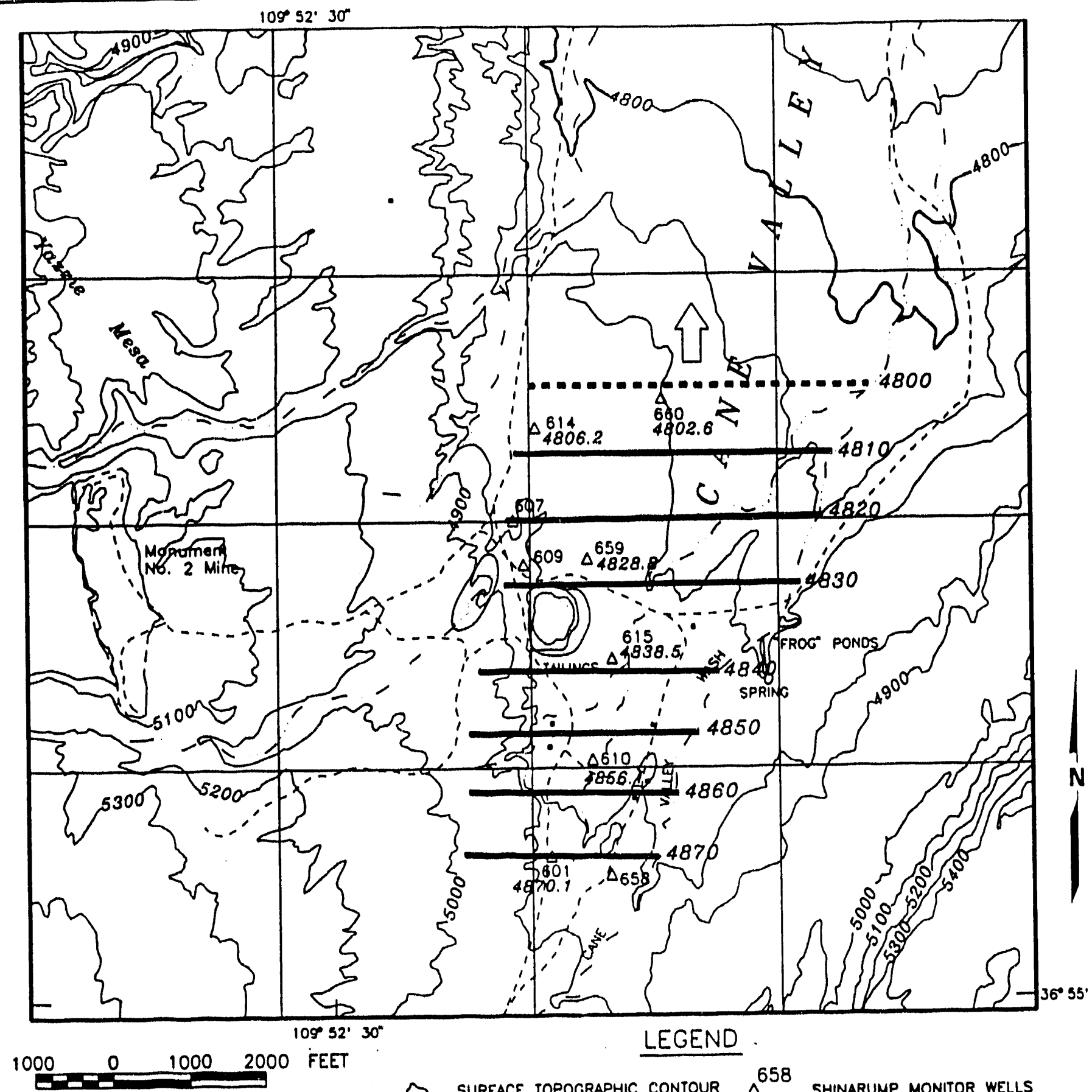

$200 \quad 0 \quad 200 \quad 400$ METERS

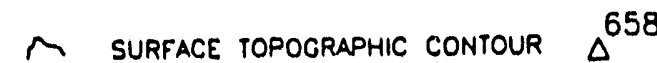
LINES 20/100 FT INTERVALS

- RESIDENCES

- - DIRT ROAO

口 DOMESTIC WELL

Oallings pile



SHINARUMP MONITOR WELLS

NOTE: POTENTIOMETRIC SURFACE BASED ON
AVERAGE STATIC $V$.TER LEVELS BETWEEN 3/85 AND 2/93. AVE: AGE VARIATION DURING PERIOD: $1.0^{\circ}$ MAXIMUM VARIATION IN ANY WELL: 1.7

FIGURE 2.8

- BASED ON 3 - PT, SOLUTION USING WELls 614, 659, AND 660

\section{POTENTIOMETRIC SURFACE FOR THE SHINARUMP CONGLOMERATE MONUMENT VALLEY, ARIZONA, SITE}




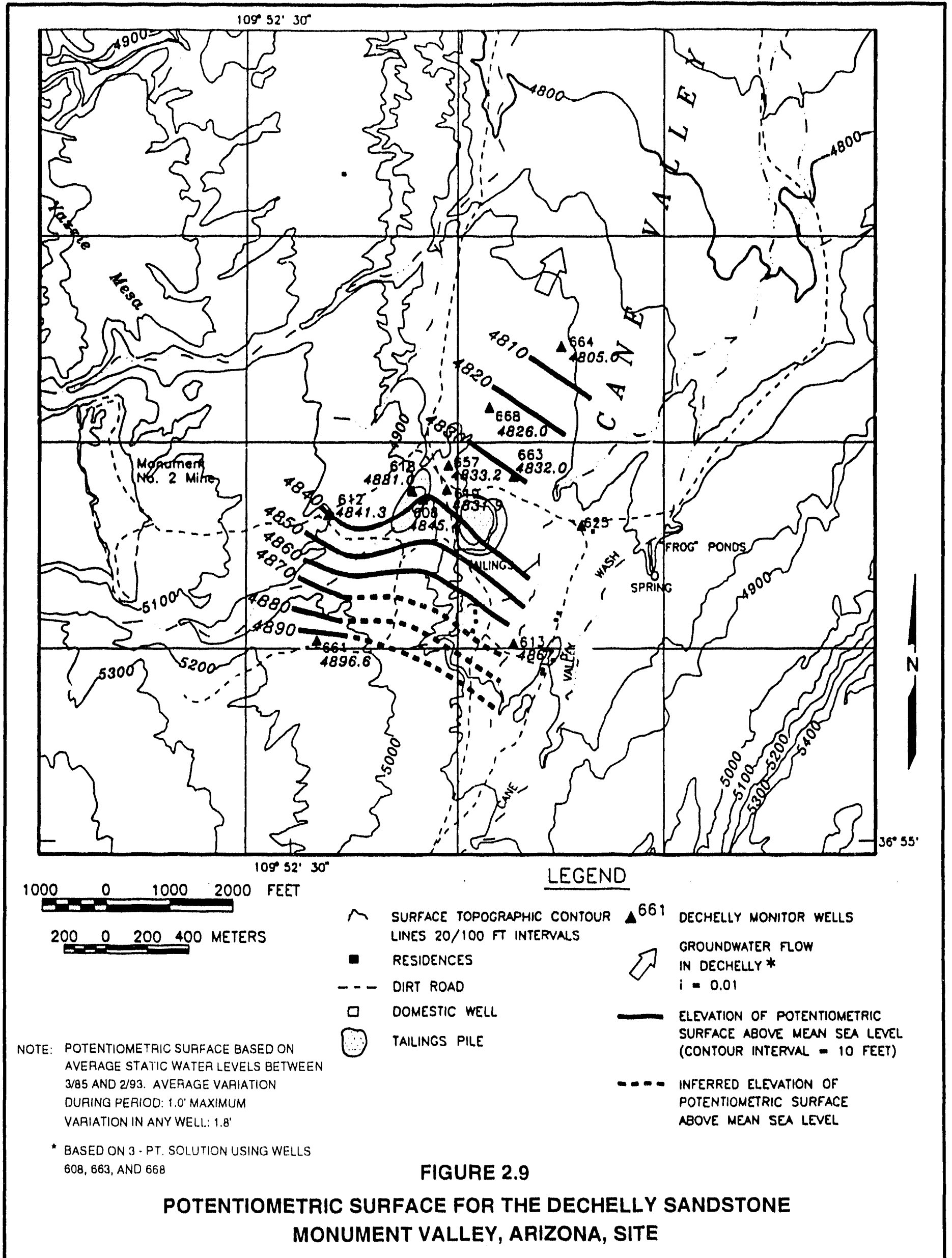




\subsubsection{Surface water regime}

Surface water features in the vicinity of the Monument Valley site include Cane Valley Wash and several small ephemeral drainage channels (arroyos) as shown in Figure 2.10. Cane Valley Wash has a drainage area of approximately 90 square miles $\left(\mathrm{mi}^{2}\right)\left(230 \mathrm{~km}^{2}\right)\{57,000$ ac $(23,000 \mathrm{ha})]$ south of the tailings site. East and South Arroyos drain about 710 ac $(290 \mathrm{ha})$ south of the tailings site. These arroyos join approximately $300 \mathrm{ft}(90 \mathrm{~m})$ east of the lower tailings pile and continue northward into the wash. West Arroyo drains a 1120-ac (453-ha) watershed on Yazzie Mesa southwest of the tailings pile. The upper tailings pile and heap-leach pad area were located in this arroyo.

The surface water flow in Cane Valley Wash is supplemented by discharge from a spring located on the east side of the wash, as shown in Figure 2.11. Water from the spring flows out of an excavation in the unconsolidated aquifer into a rectangular-shaped excavation and then into Cane Valley Wash. From there, the water flows into a series of excavated ponds and depressions on the floodplain of Cane Valley Wash. Figure 2.12 shows these ponds and the lush vegetation indicating high water table conditions in the bottom of Cane Valley downstream of the spring. Approximately $2 \mathrm{~m} / 3.2 \mathrm{~km})$ north of the site near surface sampling location 620, another series of springs that feed into Cane Valley Wash are noted on the U.S. Geological Survey (USGS) topographical maps (Figure 2.3). In wet years, the meadow region surrounding Cane Valley Wash continues for several miles, providing pasture for several herds of cattle and sheep and a watering and nesting area for waterfowl and other wildlife.

Of particular importance to this baseline risk assessment is that the spring east of the site is located on the opposite side of Cane Valley Wash from the tailings pile and is at a higher elevation than the bottom of the Wash, as shown on the topographic map in Fig' ire 2.3 and in the photograph in Figure 2.11. As discussed earlier, this spring is probably fed by groundwater moving up out of the unconsolidated aquifer from the east and south. Therefore, the quality of water from the spring probably has not and will not be affected by contaminants associated with the former milling operations. Also important is the probability that the flow from the spring is significantly greater than the contribution of groundwater to the surface water flow in Cane Valley Wash. Therefore, the uncontaminated spring outflow should dilute any contaminated groundwater that may reach the surface stream from the west, or tailings side, of the valley.

\subsection{LAND USE}

Individual members from the Navajo Nation do not literally own land; land use rights are maintained by several systems of land tenure. The Navajo system for land assignment consists of grazing permits. The grazing permit system was developed in the 1940s to assign land based on sheep units. A Navajo cannot establish a residence without a grazing permit. These permits are usually passed down or subdivided for family members. The BIA oversees permit registration. 


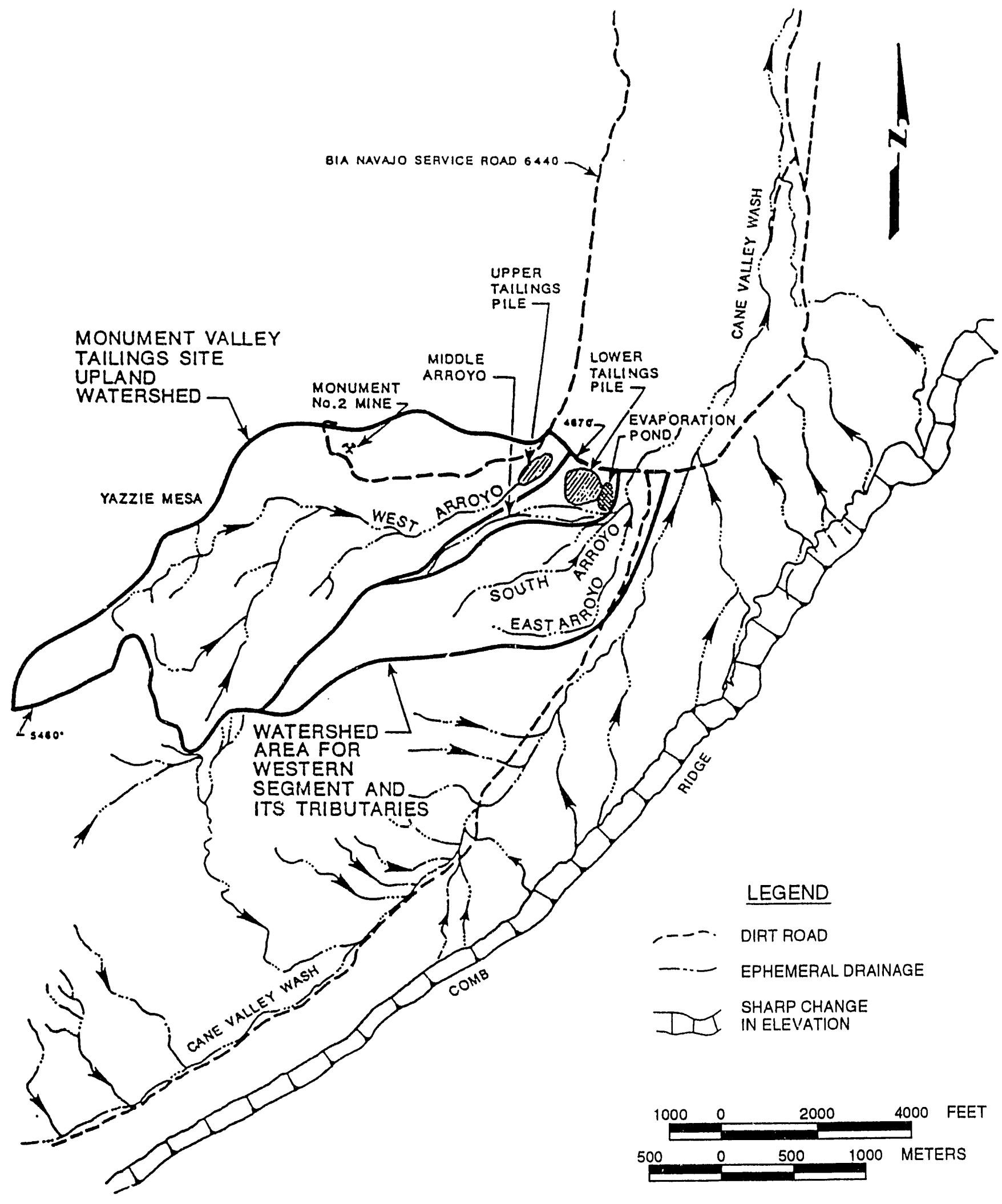

FIGURE 2.10

SURFACE WATER REGIME ILLUSTRATING EPHEMERAL DRAINAGE CHANNELS MONUMENT VALLEY, ARIZONA, SITE 


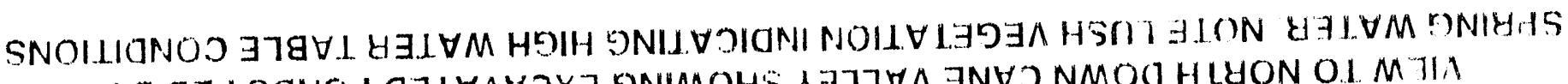

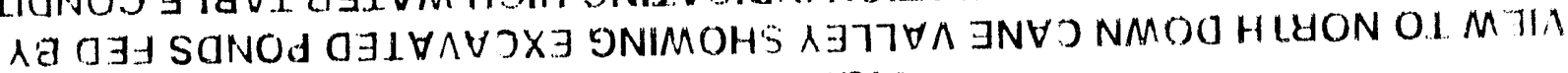
2. 2 , 7 HIISI



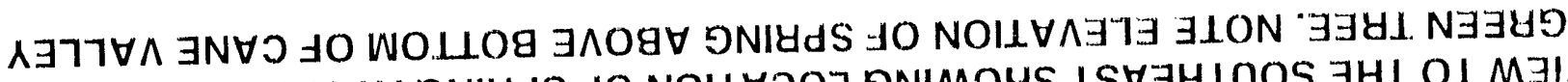


แ.

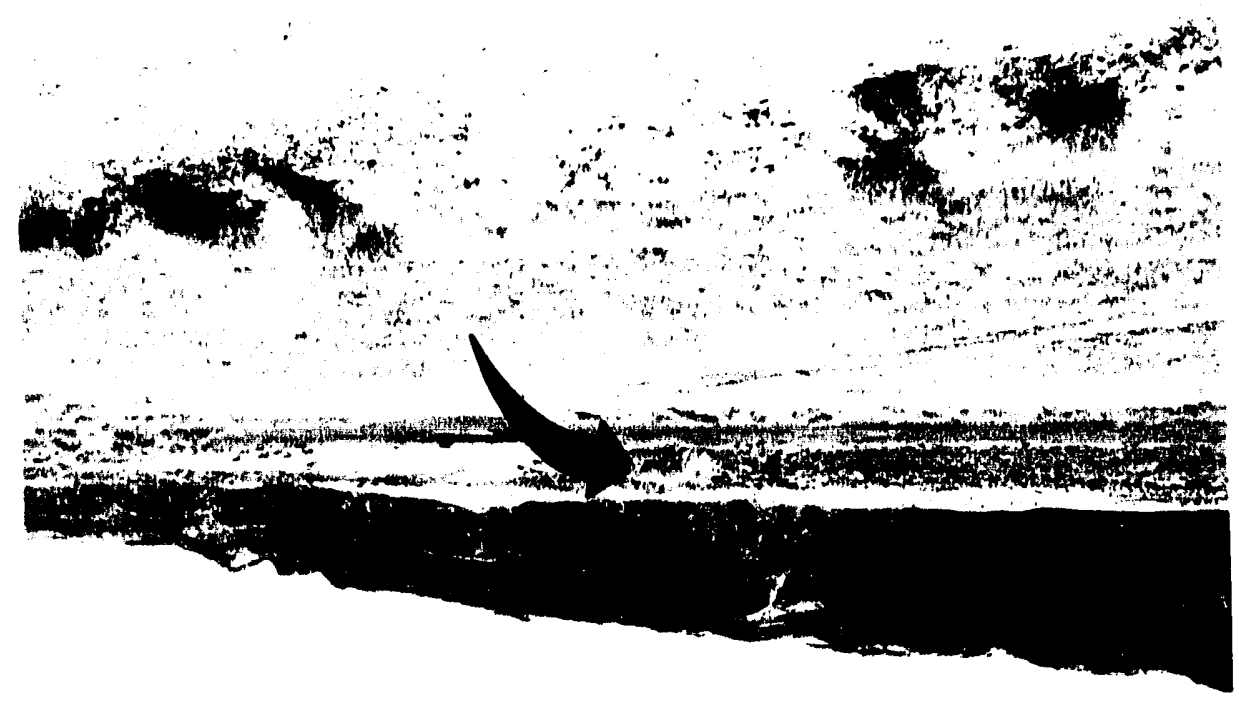


The location of area residences is noted in Figure 2.2. One occasional and six full-time residences are currently located within a $1-\mathrm{mi}(1.6-\mathrm{km})$ radius of the site. Two of the full-time residences lie due south of the tailings pile, and four residences are along the east side of Cane Valley Wash and slightly south of the pile. The remaining full-time residence is adjacent to the site at the north-east corner. Two additional full-time residences and one occasional residence are located along BIA service road 6440 within $2 \mathrm{mi}(3.2 \mathrm{~km})$ north of the site.

Most residents of the valley maintain small herds of cattle, goats, and/or sheep. These animals range freely through the valley, but the primary grazing area is a meadow in Cane Valley. The meadow is supported by the frog-pond drainage running north through the valley for several miles (see Figure 2.12). In addition to livestock, several residents maintain vegetable gardens consisting primarily of corn, squash, and melons.

\section{5}

\section{WATER USE}

Because of the limited and highly variable supply of surface water, groundwater is an important resource. Installation of wells and water systems on the Navajo reservation is funded and arranged by the Indian Health Service (IHS).

Homes in the vicinity of Monument Valley do not have plumbing, water, or sewage systems. Domestic water use referred to below encompasses drinking, bathing, and watering vegetable gardens and domestic pets. Livestock primarily drink surface water as described in later sections.

Five points of groundwater withdrawal, in addition to DOE-placed monitor wells, are known to exist within a $2.5-\mathrm{mi}(4.0-\mathrm{km})$ radius of the pile (Figure 2.2). These wells are IHS hand-pump wells at the two residences due south of the pile; one hand-dug, hand-pump well in Cane Valley Wash; a windmill-pump well at a residence $2 \mathrm{mi}(3.2 \mathrm{~km})$ north of the site; and an IHS well in Cane Valley Wash approximately $2.5 \mathrm{mi}(4.0 \mathrm{~km})$ north and slightly east of the site.

The hand-pump wells at the residences south of the pile are used as a domestic water supply by several families in the valley. These wells (616 and 617) have been monitored regularly as part of the DOE/UMTRA groundwater monitoring effort at the site. Their exact completion depth is unknown but is thought to be in the unconsolidated aquifer. Water quality in these wells shows no sign of contamination and is indistinguishable from background water quality in the region.

The hand-pump well southeast of the site in Cane Valley Wash currently is not in use because of the bitter quality of the water. Residents in the vicinity of this well carry their water from either well 616 or 617 , or they use water flowing from artesian monitor well 613, completed in the DeChelly Formation.

The residents at the northeast corner of the site currently use water from an artesian former production well. This well is also completed in the DeChelly 
Formation and has been monitored regularly by the DOE/UMTRA Project as well 625. No contamination has been observed in this well.

Residents living north of the site along BIA road 6440 obtain their water from the windmill-pump well which also appears to be completed in the DeChelly Formation. This well is also used to fill a stock pond located on the same property.

Livestock drink water pooling around the artesian monitor wells 613 and 625 , or they drink from the frog ponds or the small stream flowing north from the ponds through Cane Valley Wash. USGS maps reveal at least one additional spring approximately $2 \mathrm{mi}(3.2 \mathrm{~km})$ north of the site, east of road 6440 near surface sampling location 620, that also drains to Cane Valley Wash. During periods of drought, residents dig out springs, in the valley to water their stock. This has occurred both in the vicinity of the frog ponds and in the spring region north of the site in the proximity of sampling location 620. Although these are the only two instances that have been verified, it is likely that this access to groundwater also occurs in other locations. 


\subsection{EXTENT OF CONTAMINATION}

The locations of current monitor wells are shown for the unconsolidated aquifer, Shinarump Conglomerate, and DeChelly Sandstone in Figure 2.3. The sampling, or screened, intervals within each of these wells is given in Table 3.1, as well as the number of samples obtained since 1988. In this risk assessment, only samples from 1988 to the present were used to assess water quality. This decision is based on 1) sufficient number of samples for that period in wells used for evaluation, and 2) improved analytical detection limits and quality control procedures during that time. Table 3.1 also indicates the specific wells in each aquifer that were used to define background water quality and the wells in each aquifer that have the highest levels of contaminants and have therefore been used to determine potential health and ecological risks.

\subsection{BACKGROUND WATER QUALITY DATA SUMMARY}

Background water quality is defined as the quality of water that would be present had uranium processing activities not occurred. Background groundwater quality in the unconsolidated aquifer was evaluated by analyzing water samples collected from upgradient monitor wells 602 and 603 and from domestic wells 616 and 617 (Figures 2.2 and 2.3). This water is a sodium bicarbonate type with total dissolved solids (TDS) of $406 \pm 43$ milligrams per liter $(\mathrm{mg} / \mathrm{L})$ and $\mathrm{pH}$ of $7.73 \pm 0.23$. Background groundwater quality in the Shinarump Conglomerate was evaluated by analyzing water samples collected from upgradient wells 601 and 615 (Figures 2.3 and 2.8). This water is similar in composition to that of the unconsolidated aquifer water and is also a sodium bicarbonate type with TDS of $382 \pm 54 \mathrm{mg} / \mathrm{L}$ and $\mathrm{pH}$ of $7.77 \pm 0.63$. Background groundwater quality in the DeChelly Sandstone has been evaluated by analyzing water samples collected from upgradient wells 612 and 613 (Figures 2.3 and 2.9). This water is a mixed sodium-calcium to sodiummagnesium bicarbonate type with TDS ranging from 118 to $321 \mathrm{mg} / \mathrm{L}$ and $\mathrm{pH}$ ranging from 7.37 to 8.46 . All the background waters show oxidizing conditions (Eh greater than 400 millivolts (mV)].

\subsection{MAGNITUDE OF SITE-RELATED GROUNDWATER CONTAMINATION}

The main contaminants (in terms of mass) resulting from milling operations at the site are sulfate and nitrate. Under the geochemical conditions found in the shallow groundwater, sulfate travels essentially at the same rate as groundwater. Therefore, sulfate can be used to define the extent of the contaminant plume originating from the site.

\section{Plume definition}

The general shape of the plume has been defined by contouring sulfate concentrations in groundwater downgradient from the site. The resulting map, an isopleth map, is shown in Figure 3.1. Because there are not enough sampling points to distinguish contributions from the upper and lower tailings 
Table 3.1 Groundwater monitor well network at tailings sites

\begin{tabular}{|c|c|c|c|c|c|}
\hline \multirow[b]{2}{*}{ Well no. } & \multicolumn{5}{|c|}{ Screened interval (depth below surface) } \\
\hline & \multicolumn{2}{|c|}{$(f t)$} & \multicolumn{2}{|c|}{ (m) } & $\begin{array}{c}\text { No. samples } \\
\text { since } 1988\end{array}$ \\
\hline UNCONSOLIDATED AQUIFER & & & & & \\
\hline \multicolumn{6}{|c|}{ Upgradient } \\
\hline $602^{a}$ & 33 & 53 & 10 & 16 & 7 \\
\hline $616^{\mathrm{a}}$ & b & b & b & b & 5 \\
\hline $617^{\mathrm{a}}$ & b & b & b & b & 4 \\
\hline \multicolumn{6}{|c|}{ Crossgradient } \\
\hline $603^{a}$ & 33 & 53 & 10 & 16 & 6 \\
\hline 604 & 13 & 28 & 4 & 8 & 6 \\
\hline 605 & 14 & 29 & 4 & 9 & 8 \\
\hline 654 & 57 & 77 & 17 & 23 & 9 \\
\hline \multicolumn{6}{|c|}{ Downgradient } \\
\hline $606^{c}$ & 32 & 42 & 10 & 13 & 9 \\
\hline 650 & 78 & 98 & 24 & 30 & 2 \\
\hline 651 & 20 & 80 & 6 & 24 & 9 \\
\hline 652 & 34 & 54 & 10 & 16 & 5 \\
\hline 653 & 56 & 76 & 17 & 23 & 9 \\
\hline $655^{c}$ & 38 & 58 & 12 & 18 & 10 \\
\hline 656 & 38 & 58 & 12 & 18 & 3 \\
\hline 662 & 35.5 & 67.5 & 11 & 20 & 5 \\
\hline 669 & 34 & 54 & 10 & 16 & 2 \\
\hline \multicolumn{6}{|c|}{ SHINARUMP AQUIFER } \\
\hline \multicolumn{6}{|c|}{ Upgradient } \\
\hline $601^{a}$ & 12 & 22 & 4 & 7 & 4 \\
\hline 610 & 63 & 83 & 19 & 25 & 0 \\
\hline 658 & 135 & 155 & 41 & 47 & 0 \\
\hline \multicolumn{6}{|c|}{ Crossgradient } \\
\hline $615^{\mathrm{a}}$ & 68 & 88 & 21 & 27 & 2 \\
\hline \multicolumn{6}{|c|}{ Downgradient } \\
\hline 607 & 12.5 & 22.5 & 4 & 7 & 0 \\
\hline 609 & 7 & 12 & 2 & 4 & 0 \\
\hline $614^{\mathrm{C}}$ & 48 & 68 & 15 & 21 & 8 \\
\hline $659^{c}$ & 87 & 107 & 27 & 33 & 9 \\
\hline 660 & 133 & 153 & 41 & 47 & 6 \\
\hline
\end{tabular}


Table 3.1 Groundwater monitor well network at tailings sites (Concluded)

\begin{tabular}{|c|c|c|c|c|c|}
\hline \multirow[b]{2}{*}{ Well no. } & \multicolumn{5}{|c|}{ Screened interval (depth below surface) } \\
\hline & \multicolumn{2}{|c|}{$(\mathrm{ft})$} & \multicolumn{2}{|c|}{$(\mathrm{m})$} & $\begin{array}{c}\text { No. samples } \\
\text { since } 1988\end{array}$ \\
\hline DECHELLYY AQUIFER & & & & & \\
\hline \multicolumn{6}{|l|}{ Upgradient } \\
\hline $612^{a}$ & 175 & 195 & 53 & 59 & 1 \\
\hline $613^{a}$ & 138 & 158 & 42. & 48 & 8 \\
\hline 661 & 190 & 210 & 58 & 64 & 0 \\
\hline \multicolumn{6}{|c|}{ Crossgiadient } \\
\hline $611^{a}$ & 163 & 183 & 50 & 56 & 1 \\
\hline $625^{a}$ & b & & & & 3 \\
\hline \multicolumn{6}{|c|}{ Downgradient } \\
\hline 608 & 98 & 118 & 30 & 36 & 0 \\
\hline 619 & b & & & & 0 \\
\hline $657^{c}$ & 121 & 136 & 37 & 41 & 6 \\
\hline $663^{c}$ & 175 & 215 & 53 & 66 & 9 \\
\hline 664 & 211 & 231 & 64 & 70 & 0 \\
\hline 668 & 180 & 200 & 55 & 61 & 1 \\
\hline
\end{tabular}

aWells used to establish background water quality for purposes of risk assessment.

bWells are either domestic or production wells for which log data are not available.

"Wells with highest contaminant concentrations used in modeling potential exposures for purposes of risk assessment. 


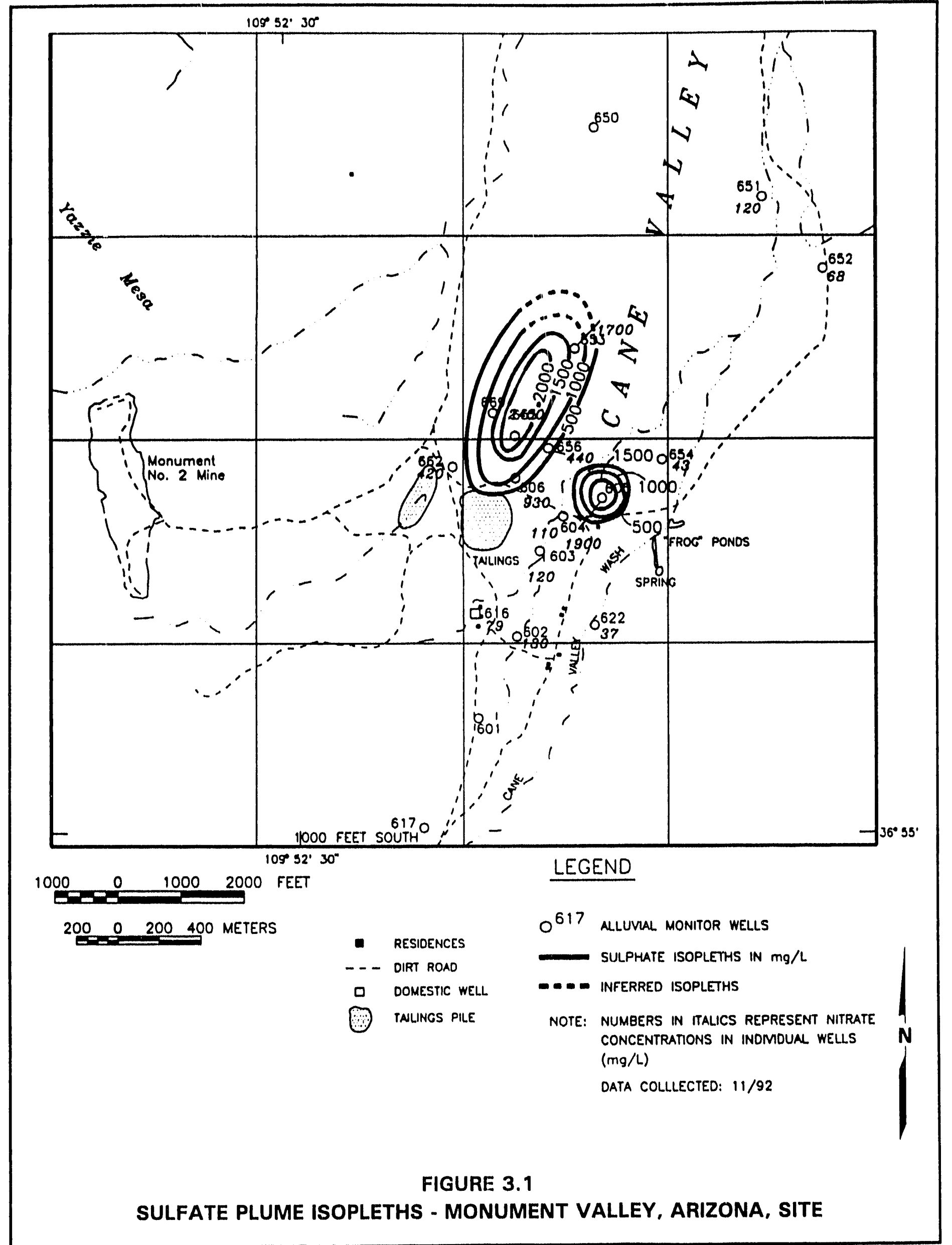


piles, only a single plume is depicted emanating from the tailings. The second, smaller plume depicted around well 605 is not thought to be site-related.

The precise periphery of the plume is difficult to define solely on the basis of sulfate concentrations. This is evident in well 605, which has high sulfate, suggesting it is in the plume but it does not have elevated concentrations of other site-related contaminants (e.g., nitrate). A better way to define the periphery of the plume is through chloride versus sulfate plots. Both of these analytes are conservative constituents in the peripheral wells and by definition travel at essentially the same rate in groundwater. Figure 3.2 shows that nearly all background groundwaters have chloride:sulfate $\left(\mathrm{Cl}: \mathrm{SO}_{4}\right)$ ratios greater than $1: 10$. Therefore, the $1: 10$ ratio provides a reasonable discriminator between the plume and background. Wells within the plume have $\mathrm{Cl}: \mathrm{SO}_{4}$ ratios that are inversely proportional to their degree of contamination. For example, in the center of the plume, well 655 has a $\mathrm{Cl:SO}$ ratio near 1:100 (Figure 3.3). The peripheral wells in the unconsolidated aquifer $\left(656,662\right.$, and 669) have $\mathrm{Cl}: \mathrm{SO}_{4}$ less than 1:10 suggesting they are within the plume (Figure 3.3). Wells 606 and 653 are intermediate in contaminant levels and fall midway between the central and peripheral wells in their $\mathrm{Cl}: \mathrm{SO}_{4}$ ratios. Although well 605 has relatively high sulfate concentrations, the $\mathrm{Cl}: \mathrm{SO}_{4}$ ratio is in the range of background values (Figure 3.4), suggesting the high sulfate in this well is not due to contamination from the site. It may reflect dissolution of evaporite (e.g., playa lake) deposits in the unconsolidated aquifer. Downgradient unconsolidated aquifer wells $650,651,652$, and 654 generally have $\mathrm{Cl}: \mathrm{SO}_{4}$ greater than 1:10 and are not impacted by the plume (Figure 3.4).

Based on $\mathrm{Cl}: \mathrm{SO}_{4}$ ratios, groundwaters from Shinarump wells 614 and 659 and deeper well 657 may also contain a small plume component as shown in Figure 3.5. As discussed in Section 2.3.3, well 657 was originally drilled as a DeChelly monitor well. However, the driller's log indicates that the sandpack brackets the unconsolidated aquifer and DeChelly Sandstones in a region where the Shinarump Conglomerate and Moenkopi Formation are absent. Therefore, it is difficult to determine how representative this well is of the DeChelly Sandstone.

Figures 3.6 to 3.9 present the observed concentrations of nitrate, uranium, strontium, and sulfate for background and plume wells in the unconsolidated aquifer and for corresponding wells in the deeper zones. These constituents associated with the plume are slightly but consistently elevated above background in wells 614 and 657 (Figures 3.6 to 3.9). Well 659 does not show elevated concentrations of these constituents. The $\mathrm{Cl}: \mathrm{SO}_{4}$ ratios less than $1: 10$, in combination with concentrations of the four main plume contaminants over background levels, reinforces the conclusion that some site-related contamination may be present in these wells $(657$ and 614$)$. A puzzling aspect of the water quality in these wells is that uranium concentrations actually increase with well depth from 655 to 614 to 657 (Figure 3.7), while other contaminants decrease with depth and show only minor elevations from background. Because there is no geochemical explanation for preferential migration of uranium from the tailings piles through groundwater, these elevated levels may reflect contribution from a nearby uranium ore body in addition to site-related effects as evidenced by the presence of nitrate. 


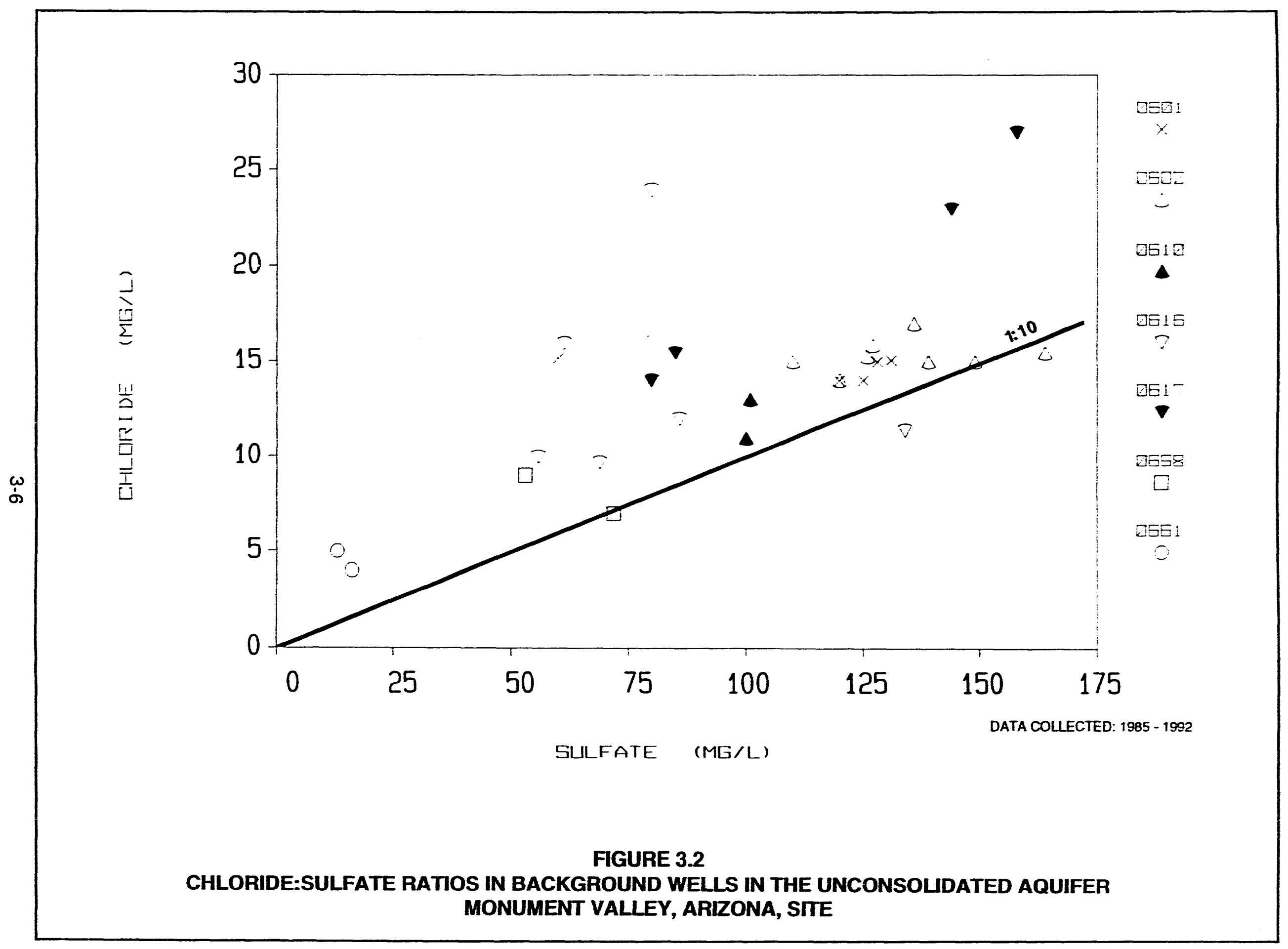






FIGURE 3.3

CHLOAIDE:SULFATE RATIOS IN BACKGROUND WELS $(602,603)$

AND PLUME WELLS $(606,653,655,656,662,669)$ WN THE UNCONSOLIDATED AQUIFER

MONUMENT VALLEY, ARIZONA, STIE 


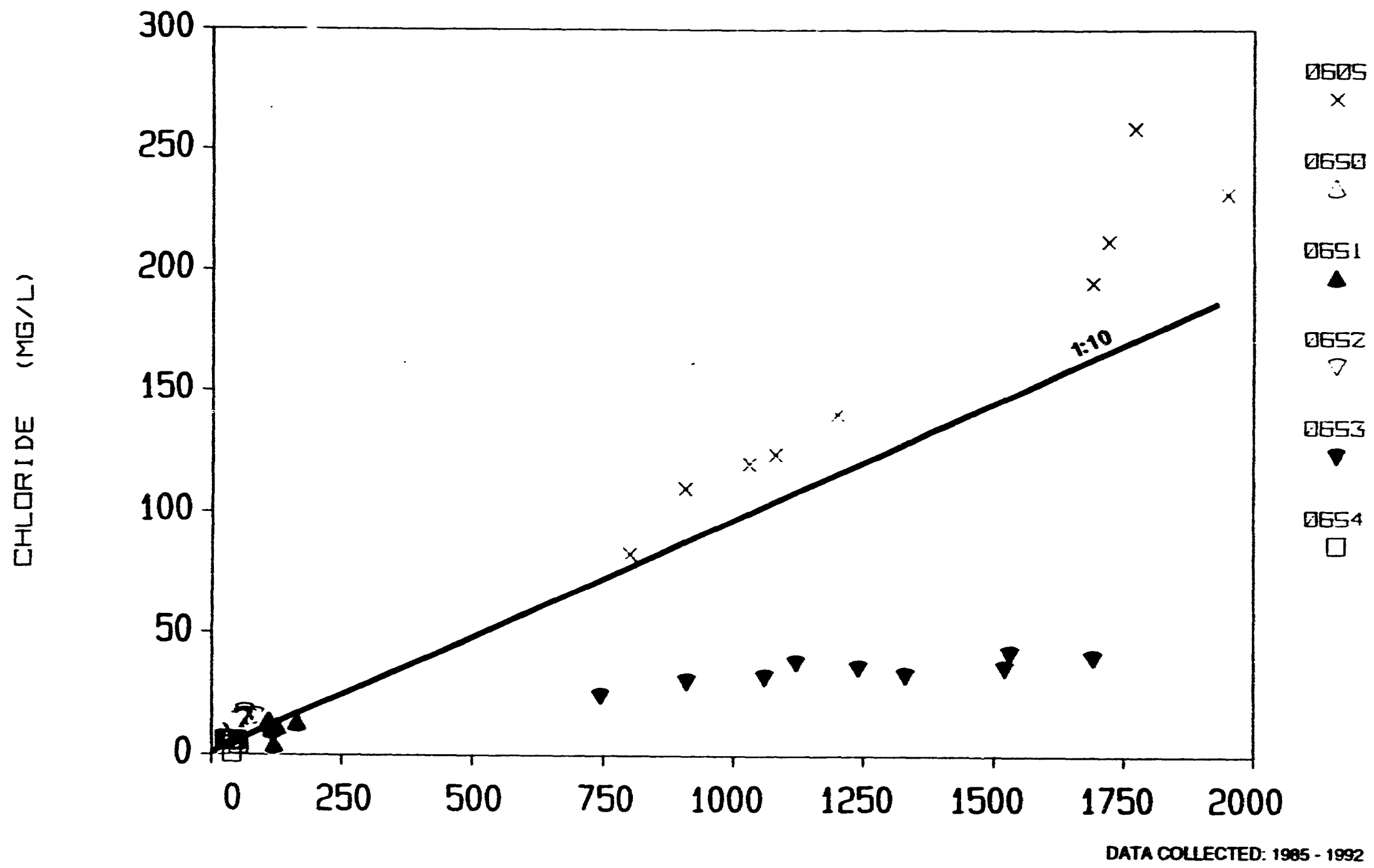

SULFATE (MG/L)

FIGURE 3.4

CHLORIDE:SULFATE RATIOS IN THE UNCONSOLIDATED AQUIFER

COMPARISON BETWEEN 605, BACKGROUND WELLS, AND CONTAMINATED WELL 653 MONUMENT VALLEY, ARIZONA, SITE 




FIGURE 3.5

CHLORIDE:SULFATE RATIOS FOR SHINARUMP AND DECHELLY WELLS: BACKGROUND $(601,613,615)$ AND DOWNGRADIENT $(614,657,659,663)$ MONUMENT VALLEY, ARIZONA, STTE 


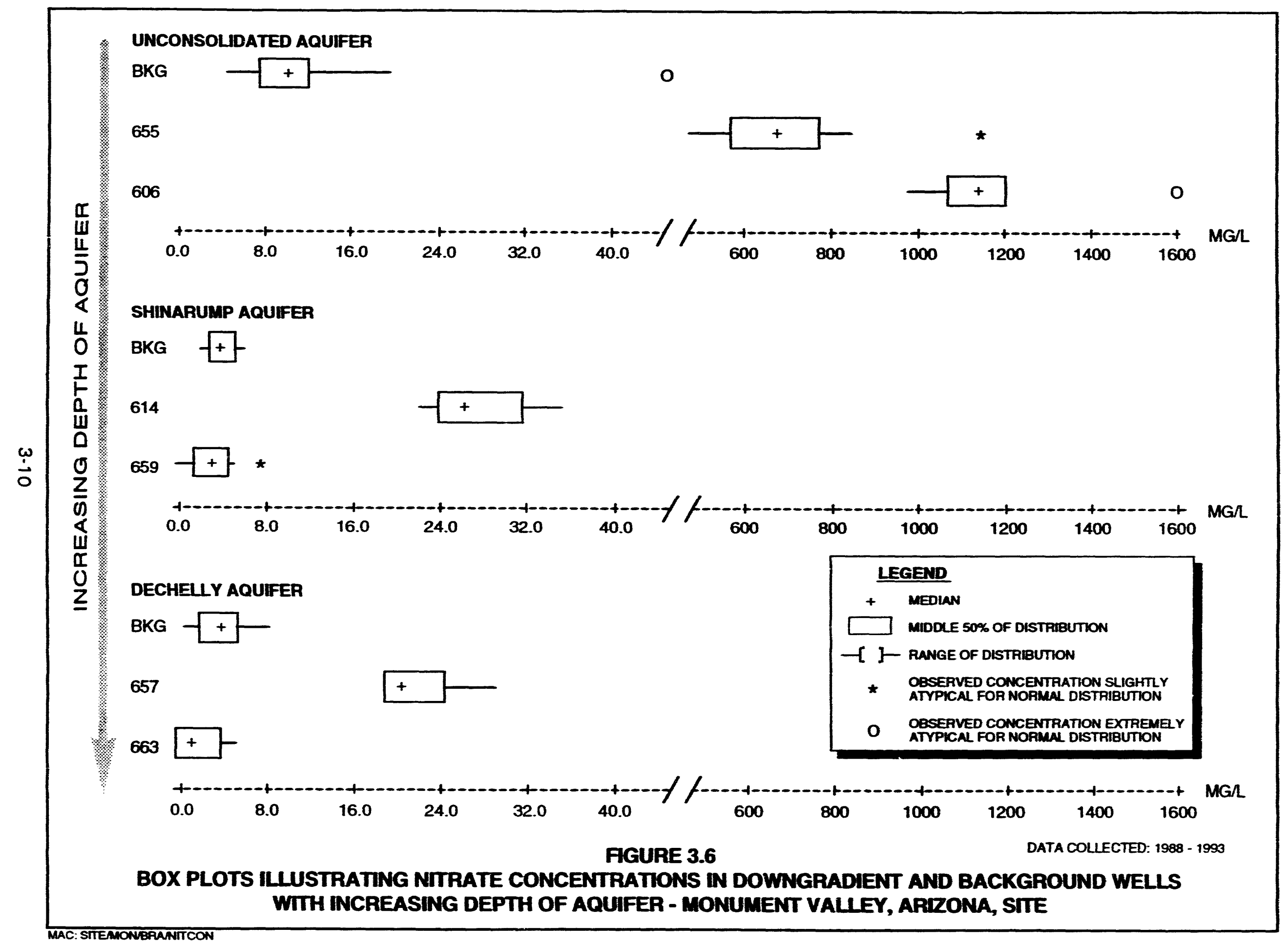




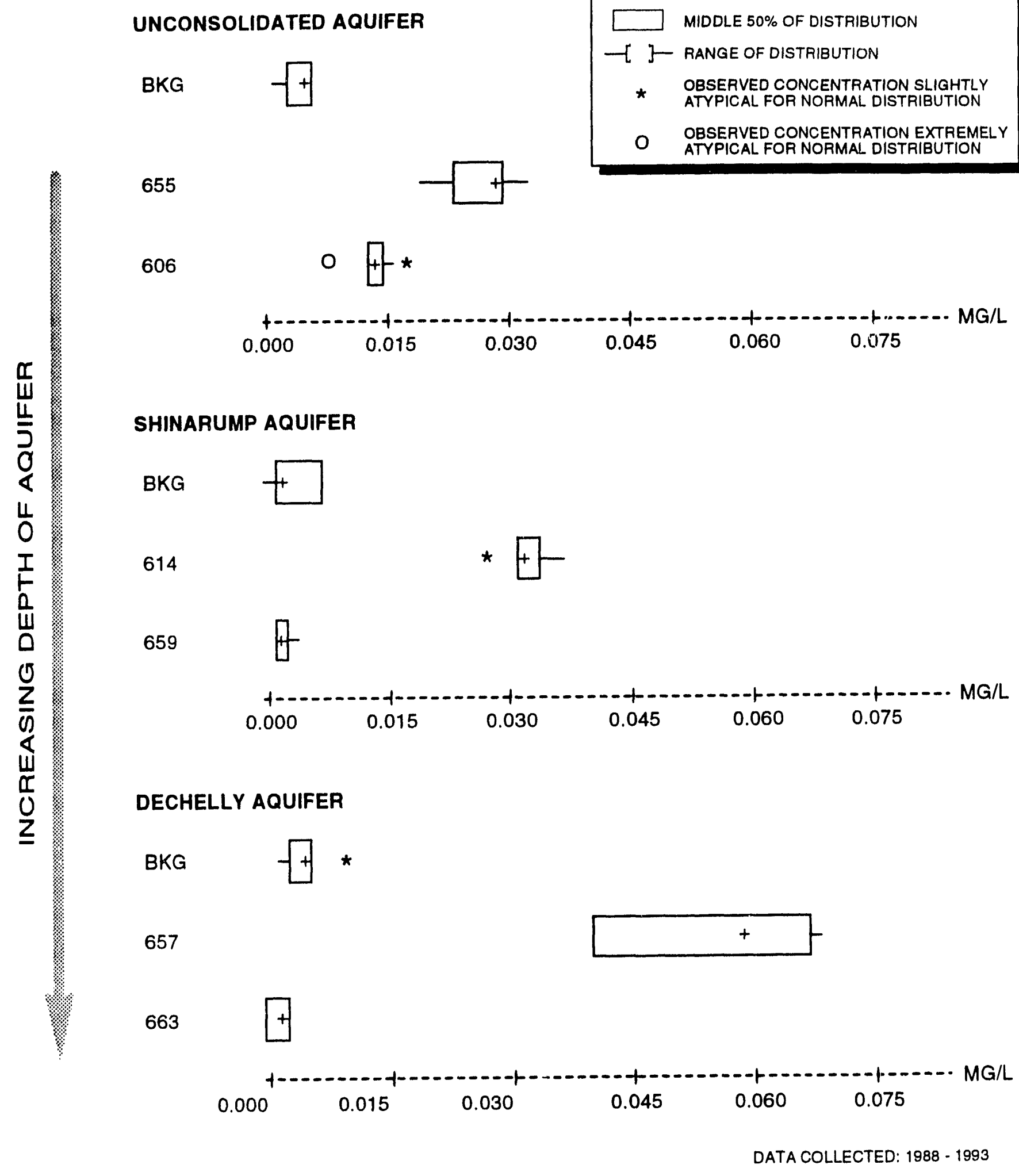

FIGURE 3.7

BOX PLOTS ILLUSTRATING URANIUM CONCENTRATIONS IN DOWNGRADIENT AND BACKGROUND WELLS WITH INCREASING DEPTH OF AQUIFER MONUMENT VALLEY, ARIZONA, SITE 


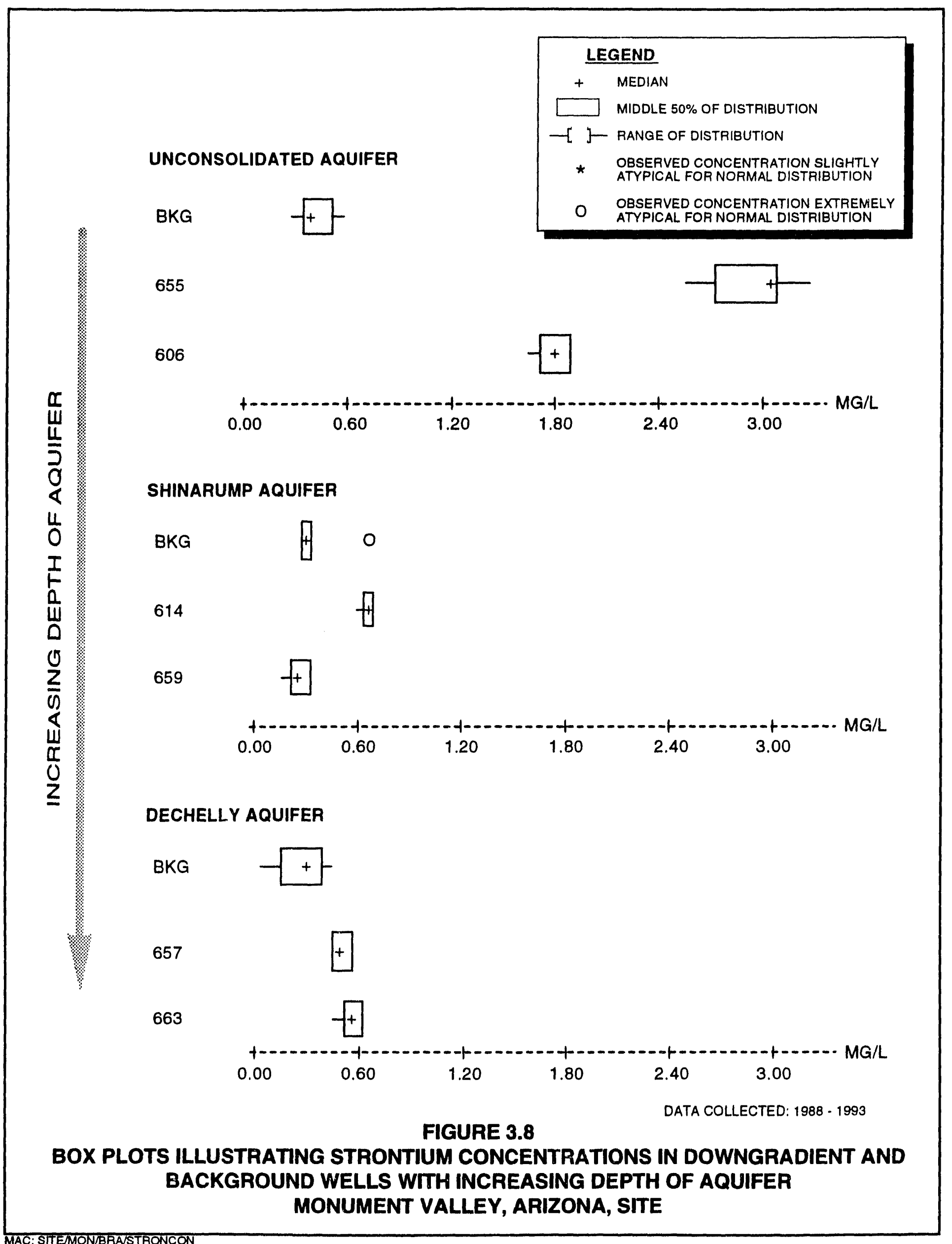




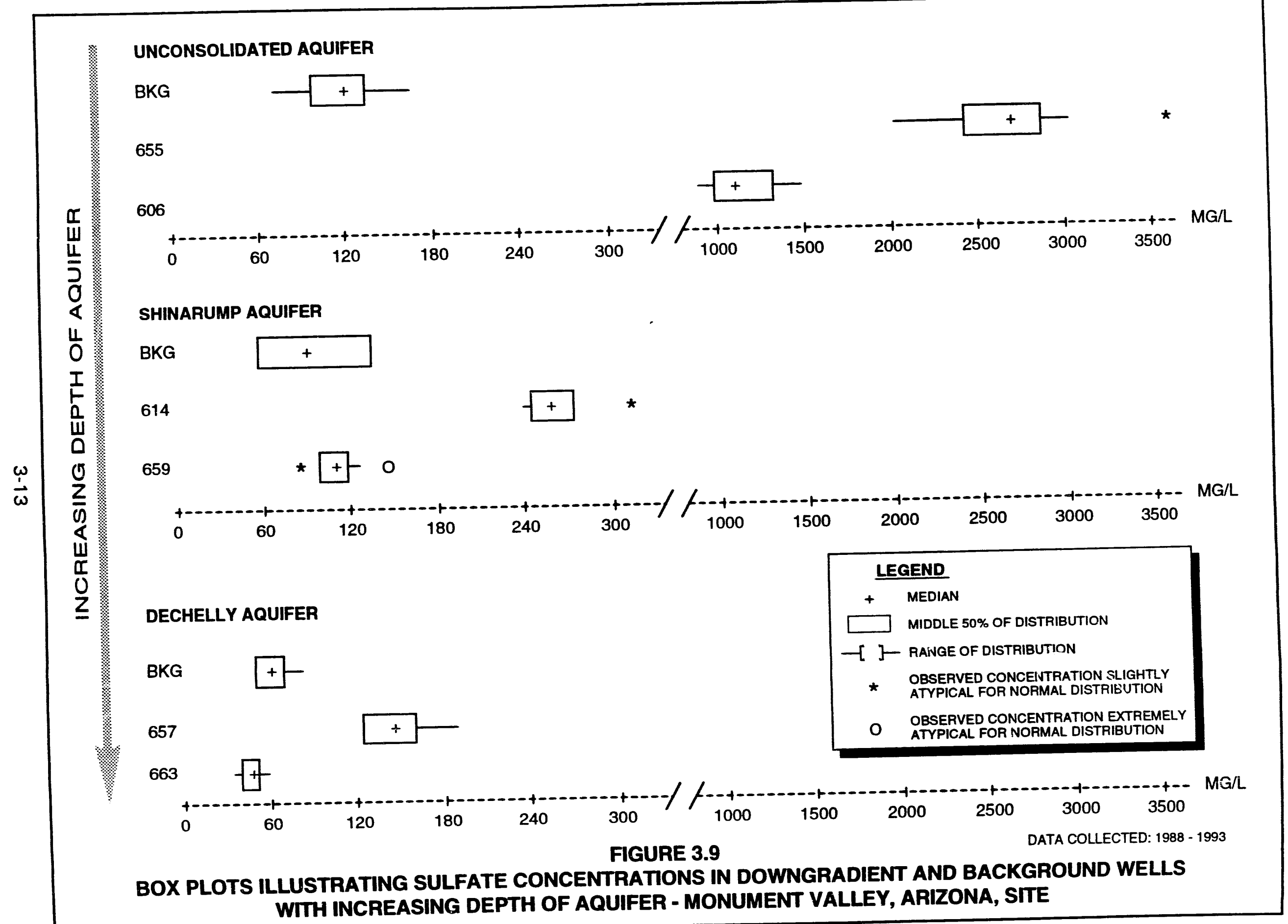


An isopleth map of nitrate concentrations in unconsolidated aquifer groundwater is shown in Figure 3.10. The figure shows that elevated nitrate concentrations are found at locations up to $3000 \mathrm{ft}(900 \mathrm{~m})$ downgradient of the tailings pile. Within the plume, nitrate concentrations range up to $1600 \mathrm{mg} / \mathrm{L}$ as nitrate.

\subsection{CONTAMINANTS OF CONCERN}

The data presented in Sections 3.1 and 3.2 are summarized in Table 3.2 for the unconsolidated aquifer. These data were used to compile a list of contaminants of potential concern for the assessment of human health or environmental risks at the Monument Valley site. Corresponding data for the Shinarump Conglomerate are presented in Table 3.3. In general, a contaminant was placed on the list of contaminants of potential concern (Table 3.4) if the contaminant was detected in excess of background in monitor wells and if the site is a likely source for the contaminant. Although some constituents not identified as exceeding background have either median or maximum values that appear to exceed background, these constituents can not be said to exceed background for the following reasons: 1 ) insufficient number of samples in either background or downgradient wells, 2) differences in detection limits between background and downgradient analyses (due to different sampling dates), or 3) detection of the constituent in only one or two of the much larger total number of samples analyzed.

The constituents identified in column 1 of Table 3.4 were screened for their impact on human health using the criteria discussed below to develop a final list of contaminants of concern for human health. Because ecological impacts differ from effects on human health, the complete list of contaminants will be considered for ecological risk assessment in Section 7.0 Several constituents that were detected above background were deleted from the final list of contaminants of potential concern for human health because they are essential nutrients and the levels at which they are detected are within nutritional ranges. These chemicals include chloride, iron, manganese, potassium, and zinc.

Final screening of the remaining contaminants was based on the very low toxicity and relatively high normal dietary intake compared to the values detected. This criterion was used to rule out calcium, magnesium, silica, and sodium.

Although ammonium is not considered as a dietary component, it is produced in the human body at levels that exceed $4000 \mathrm{mg} / \mathrm{day}$ (Summerskill and Wolpert, 1970 ), roughly an order of magnitude more than would result from ingestion of the most ammonium-contaminated water at the site $(381 \mathrm{mg} / \mathrm{L})$. Although these levels are substantially higher than background, they are not likely to be associated with adverse health effects. However, the detected concentrations are likely to affect the taste and odor of the water.

Screening based on the criteria described above eliminated all of the contaminants from consideration except nitrate, strontium, sulfate, vanadium, 




FIGURE 3.10

NITRATE PLUME IN UNCONSOLIDATED GROUNDWATER MONUMENT VALLEY, ARIZONA, SITE 


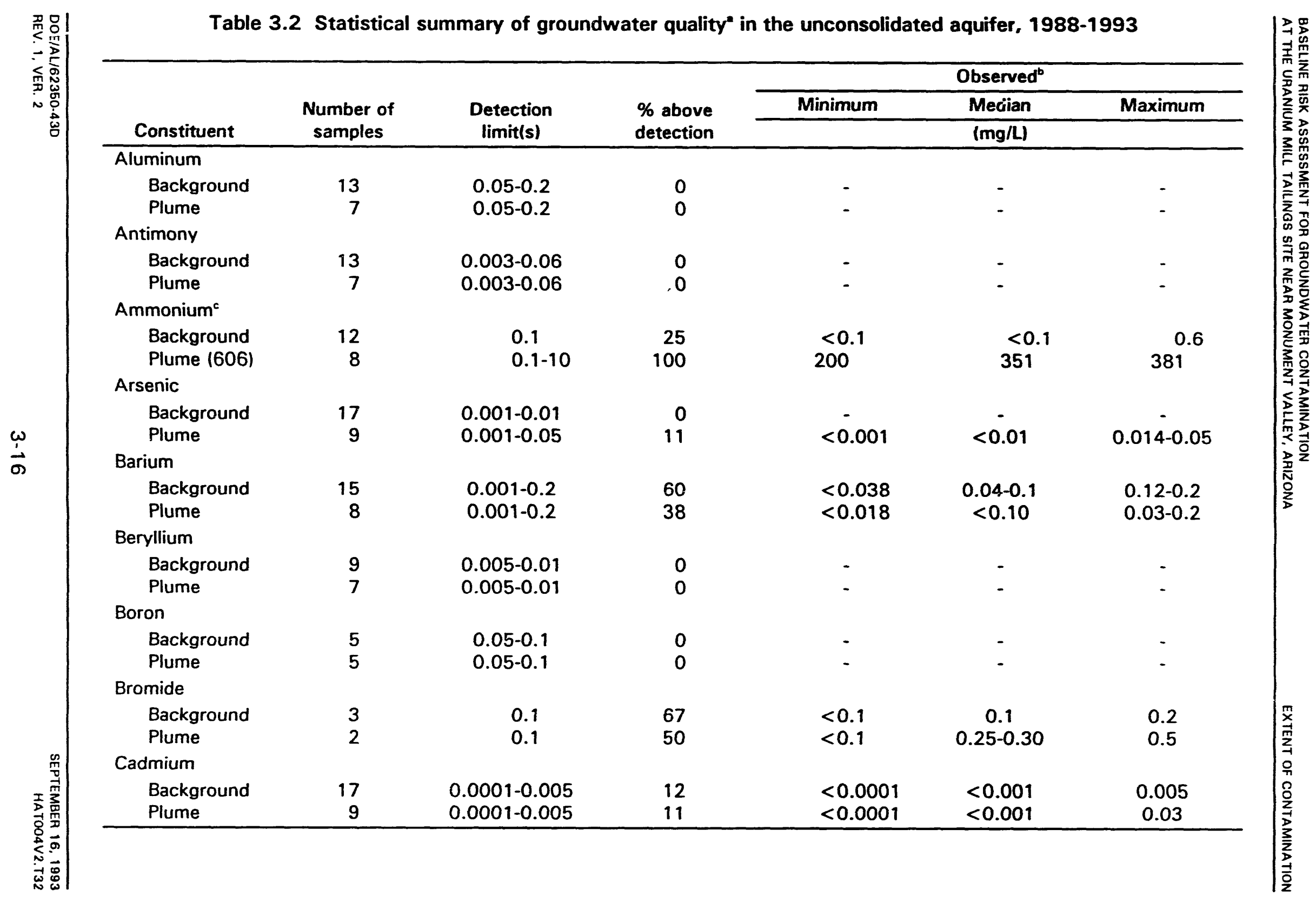




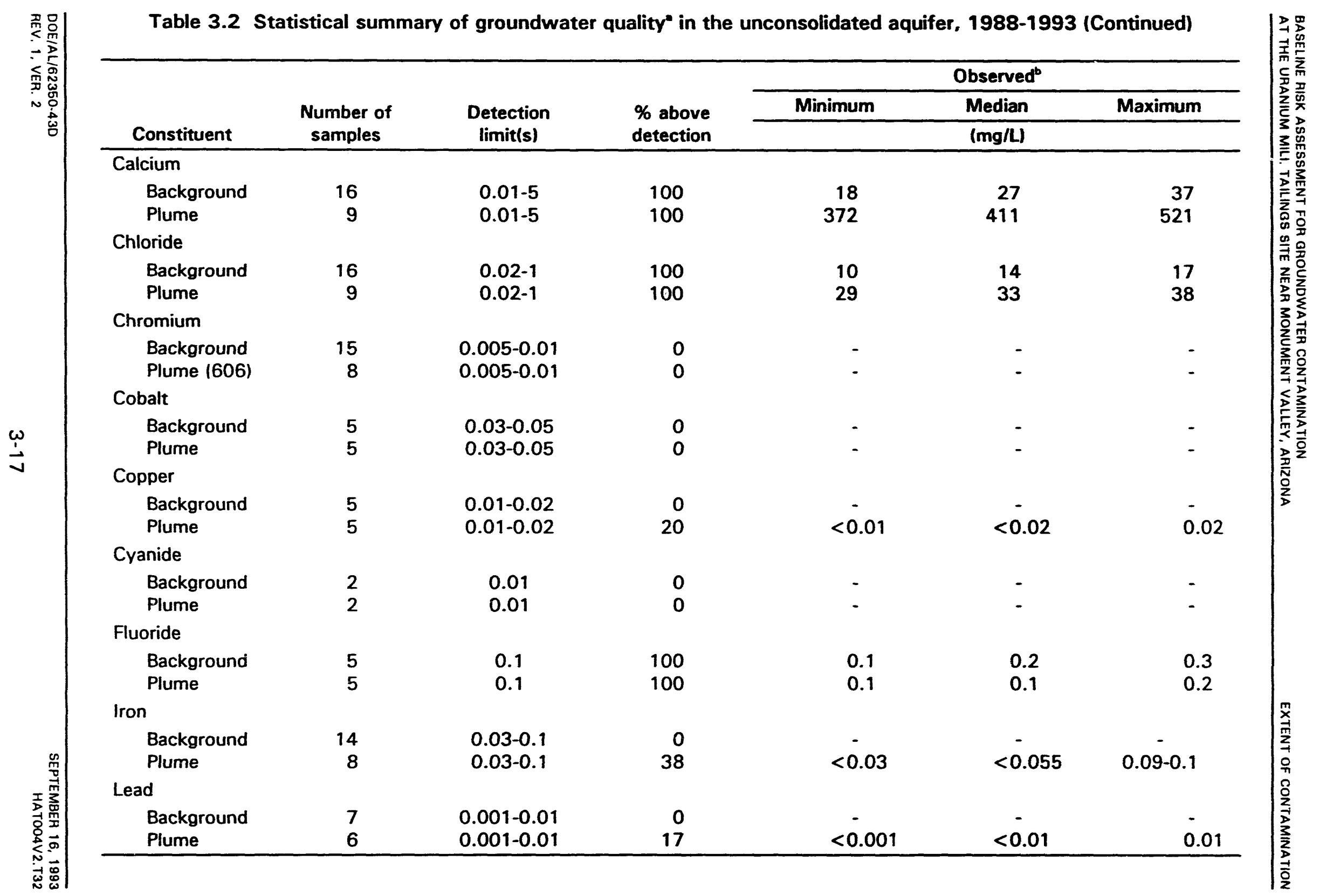




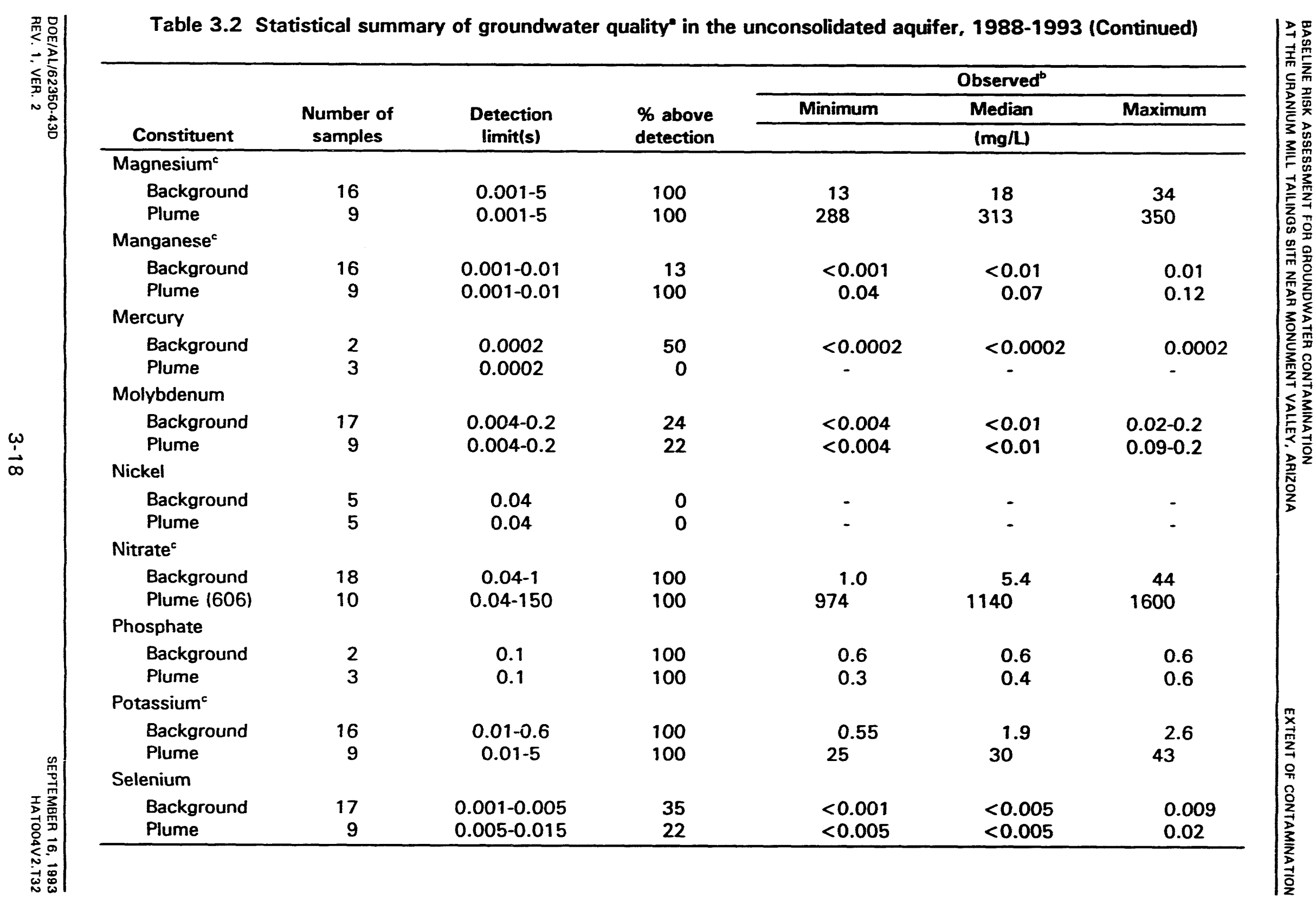




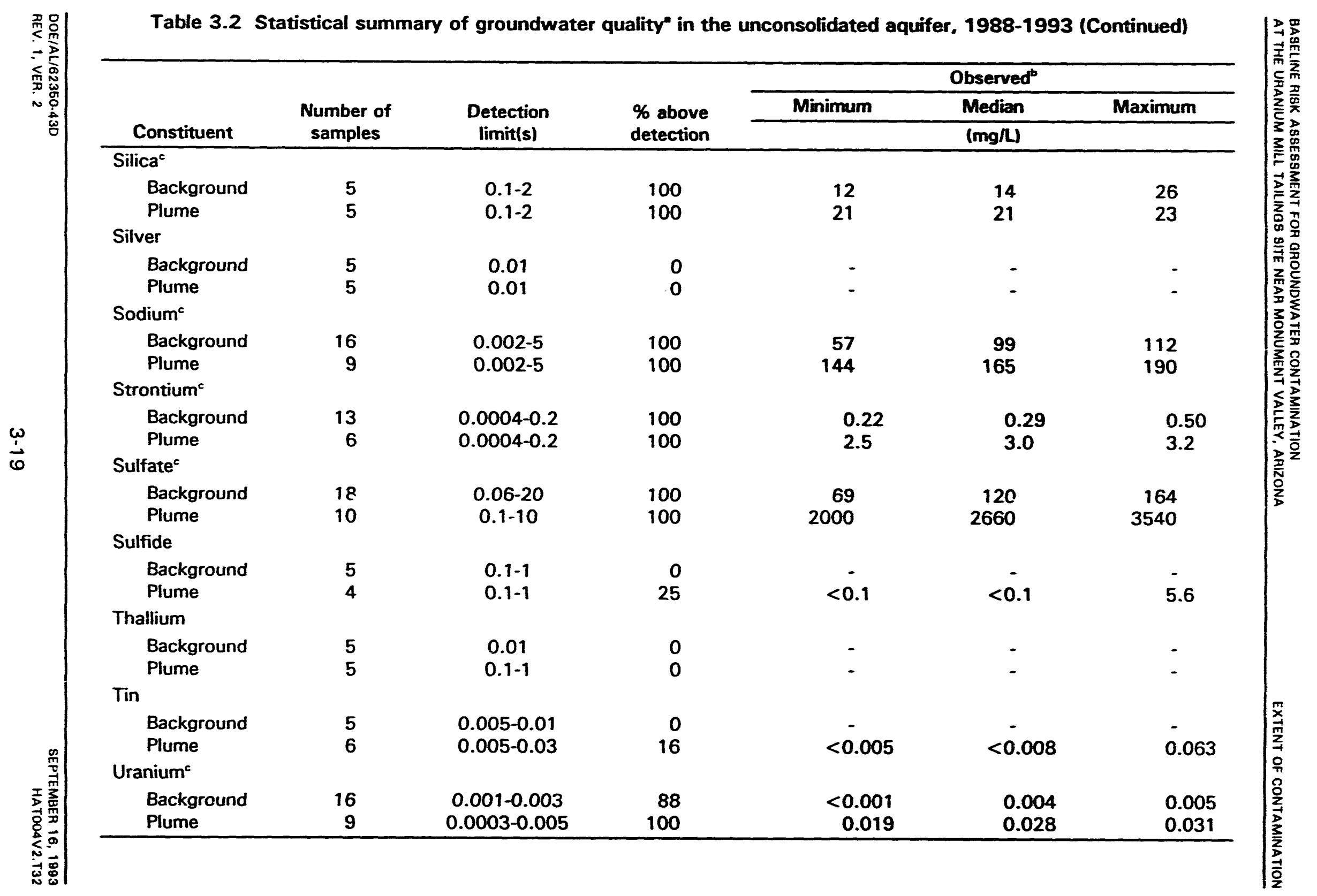









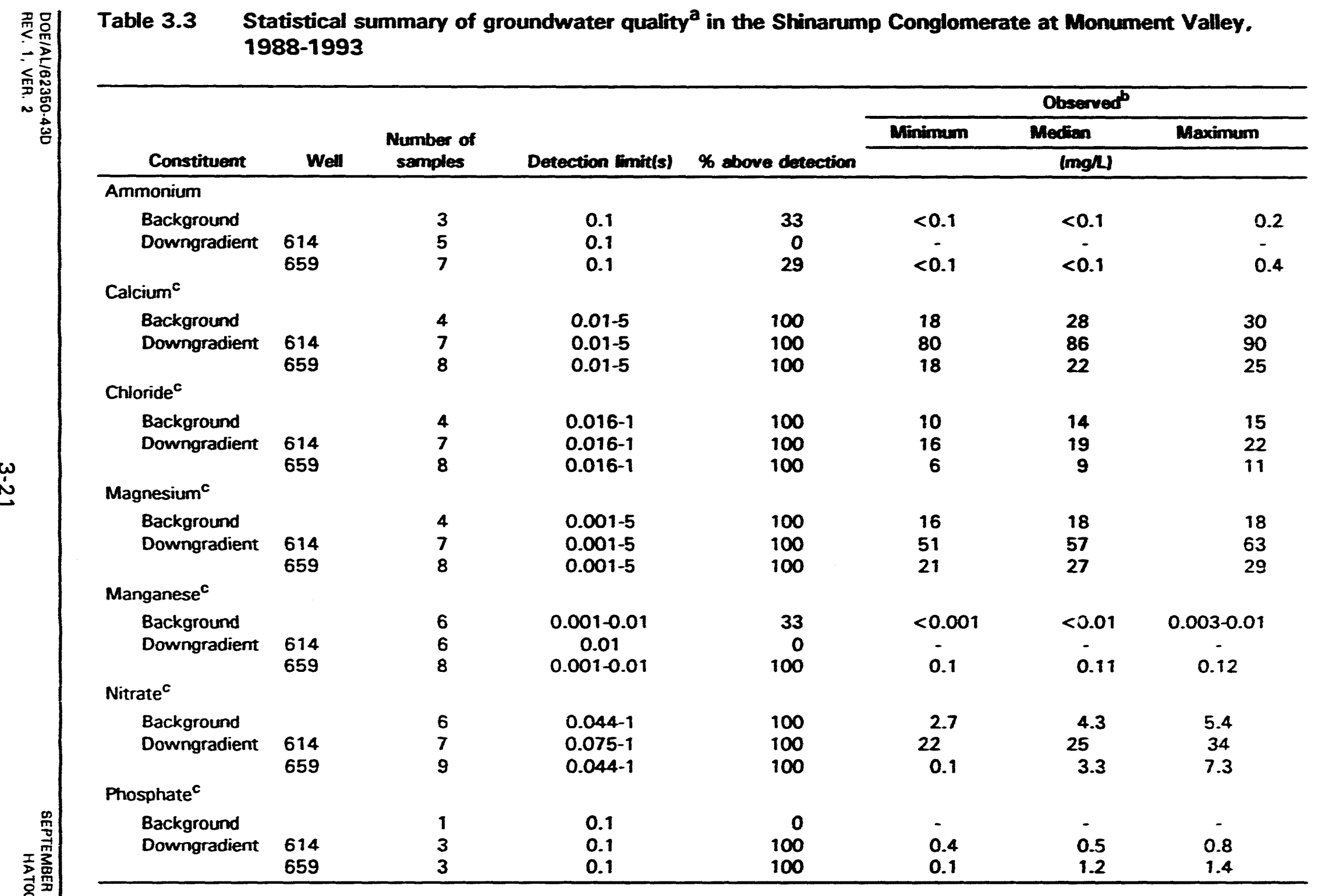




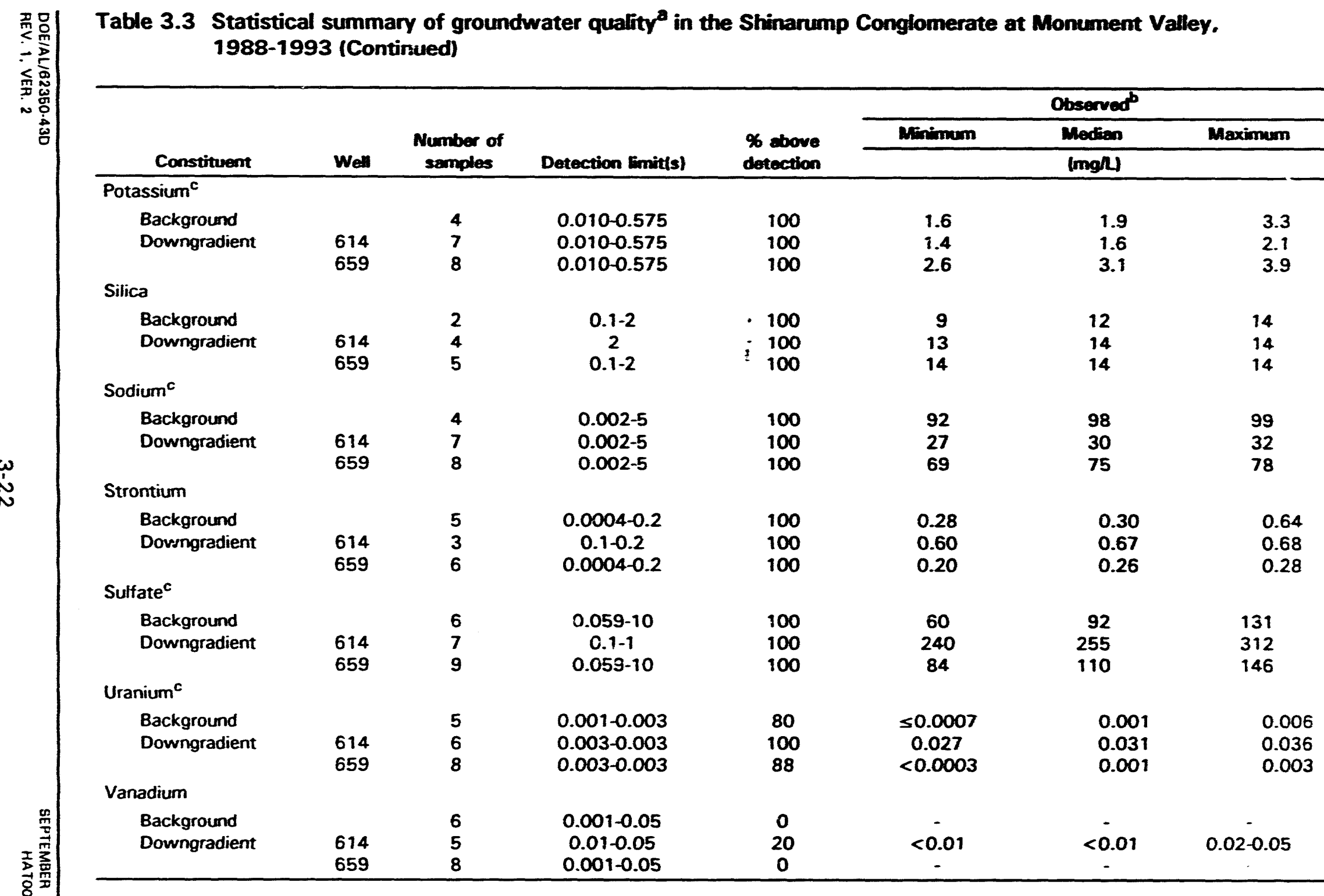




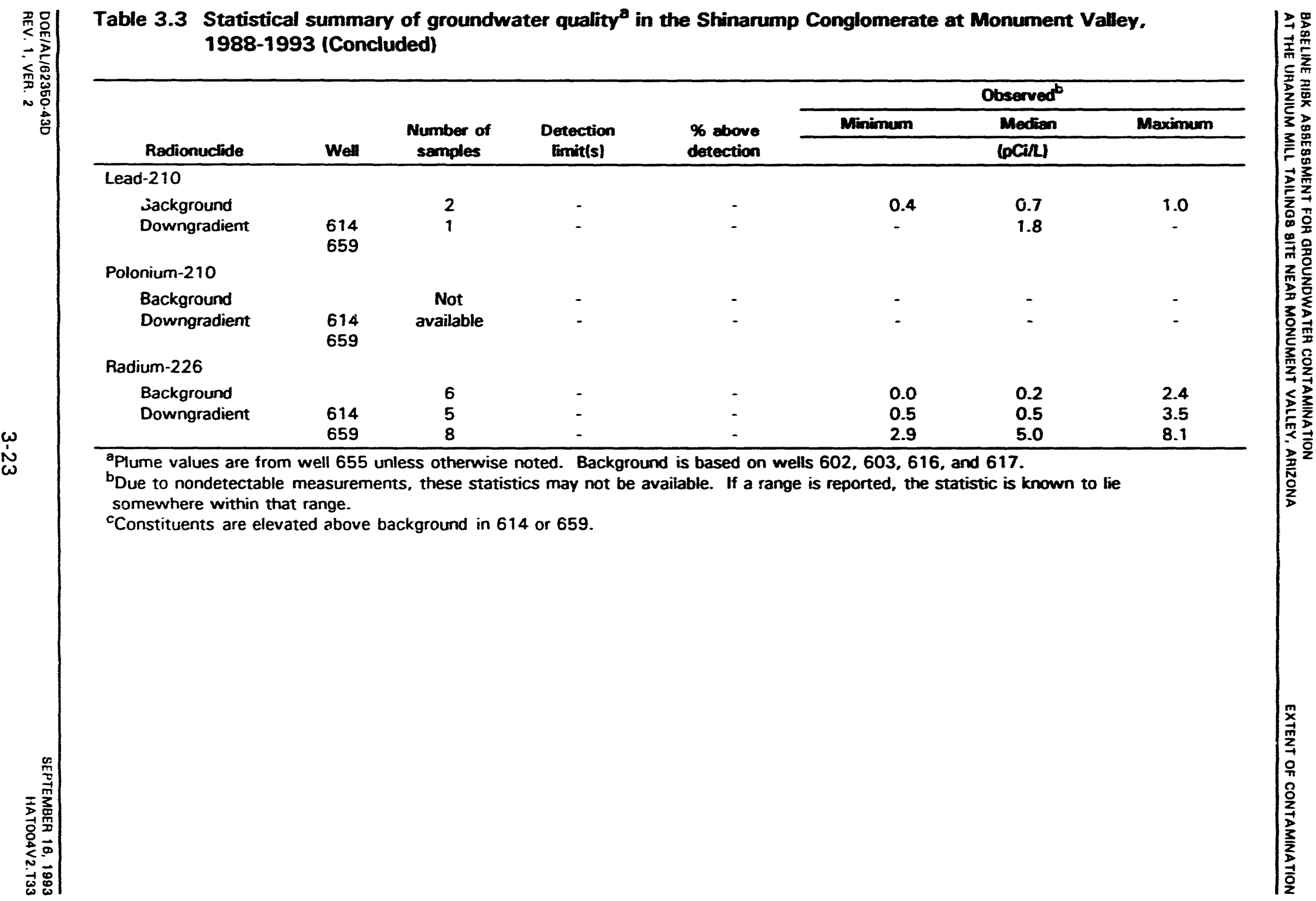


Table 3.4 Contaminants of potential concern for human health evaluation

\begin{tabular}{llll}
\hline $\begin{array}{c}\text { Contaminant levels } \\
\text { exceed background }\end{array}$ & $\begin{array}{c}\text { Contaminant levels in } \\
\text { nutritional range }\end{array}$ & $\begin{array}{c}\text { Contaminants of low } \\
\text { toxicity and high } \\
\text { dietary range }\end{array}$ & $\begin{array}{c}\text { Contaminants } \\
\text { of potential } \\
\text { concern } \\
\text { (human health) }\end{array}$ \\
\hline $\begin{array}{l}\text { Ammonium } \\
\text { Calcium }\end{array}$ & $\begin{array}{c}\text { Ammonium } \\
\text { Chloride }\end{array}$ & Calcium & \\
$\begin{array}{l}\text { Iron } \\
\text { Magnesium }\end{array}$ & Chloride & Magnesium & \\
Manganese & Iron & & Nitrate \\
Nitrate & Manganese & & \\
$\begin{array}{l}\text { Potassium } \\
\text { Silica }\end{array}$ & Potassium & Silica & \\
Sodium & & Sodium & Strontium \\
Strontium & & & Sulfate \\
Sulfate & & & Vanadium \\
Vanadium & & & Uranium \\
Uranium & & & \\
Zinc & & & \\
\hline
\end{tabular}


and uranium. These constituents form the basis of the risk assessment for Monument Valley.

3.4

\section{CONTAMINANT FATE AND TRANSPORT}

Hazardous constituents in the plume waters will be subject to dilution and various chemical reactions including oxidation/reduction reactions, precipitation and coprecipitation reactions, assorption onto aquifer mineral surfaces, and possibly reactions with biologic organisms. The concentrations of the dominantly cationic metals such as strontium and the major cations calcium, magnesium, potassium, and sodium will be controlled by dilution, precipitation reactions, and sorption (e.g., ion exchange) reactions. Manganese and zinc concentrations will also be controlled by these processes. Chloride concentrations will be affected only by dilution.

Uranium and vanadium concentrations will be decreased mainly by dilution and adsorption. Ammonium concentrations will decrease as a result of ion exchange reactions on clays and as a result of oxidation to nitrate perhaps mediated by bacterial action. Nitrate concentrations will decrease as a result of dilution and possibly natural denitrification reactions involving indigenous organisms. These reactions may produce nitrogen, which would be released to the atmosphere.

Sulfate concentrations will be subject to dilution, precipitation/dissolution reactions, adsorption reactions, and possibly oxidation/reduction reactions. The precipitation/dissolution reactions will occur in the portion of the plume closest to the tailings piles. Precipitation reactions are active at the present time because the shallow groundwater in this zone is oversaturated with gypsum. After the tailings piles are removed, the groundwater sulfate concentrations in this zone will decrease, allowing gypsum to redissolve. This dissolution will buffer the sulfate concentrations at fairly high levels until the gypsum is exhausted. At this point, dilution with background waters will substantially lower the sulfate concentrations in this zone. Adsorption reactions are not likely to have a significant effect on the sulfate concentrations in the shallow groundwater because of the relatively high concentrations involved. Given the high redox potential of the shallow groundwater, reduction of sulfate to sulfide is unlikely as well.

The chemical species present in natural systems are a function of $\mathrm{pH}$, Eh, and the concentrations of various anions and cations. Speciation determines the mobility of the chemicals and may also influence their toxicity. Using the geochemical model PHREEQE, the predominant species of the contaminants of concern for human health were predicted (Parkhurst et al., 1980). The dominant solution species for the hazardous contaminants of concern are listed in Table 3.5. 
Table 3.5 Monument Valley speciation summary

\begin{tabular}{lcc}
\hline Contaminant of concern & $\begin{array}{c}\text { Identity of species } \\
\text { in groundwater }\end{array}$ & Molar \% \\
\hline Nitrate & $\mathrm{NO}_{3}{ }^{-}$ & 100 \\
Strontium & $\mathrm{Sr}^{2+}$ & 100 \\
Sulfate & $\mathrm{SO}_{4}{ }^{2 \cdot}$ & 100 \\
Uranium & $\mathrm{UO}_{2}\left(\mathrm{CO}_{3}\right)^{4 \cdot}$ & 70 \\
& $\mathrm{UO}_{2}\left(\mathrm{CO}_{3}\right)^{2 \cdot}$ & 30 \\
Vanadium & $\mathrm{HV}_{2} \mathrm{O}_{7}{ }^{3 \cdot}$ & 83 \\
& $\mathrm{H}_{2} \mathrm{VO}_{4}$ & 15 \\
\hline
\end{tabular}




\subsection{EXPOSURE ASSESSMENT}

\subsection{POTENTIALLY EXPOSED POPULATION}

Exposure can occur only if there are both a source of contamination and a mechanism of transport to a receptor population or individual. Groundwater contaminated by uranium processing at the Monument Valley site is not currently used. In the future, if the contaminant plume continues to move to the north-northeast, surface expression is possible during wet seasons when the water table is elevated in the unconsolidated aquifer. If this expression occurs in Cane Valley, livestock could drink the water. Using these livestock for food would create an exposure pathway to humans. Plants with roots in the unconsolidated aquifer or irrigated with water from this zone could take up and concentrate contaminants, forming a pathway to humans through plant consumption. Finally, a domestic well could be drilled or hand-dug in the unconsolidated aquifer, creating an exposure pathway through drinking and bathing water.

Because there are no current human receptors of contaminated groundwater, a future groundwater use scenario must be assumed. This scenario evaluates domestic groundwater use consistent with current use by the rural population in the region. The potentially exposed population includes Navajos of the following age groups: infants (birth to $1 \mathrm{yr}$ old), children ( 1 to $10 \mathrm{yr}$ old), and adults (11 to $64 \mathrm{yr}$ old). These age groups were selected for the following reasons:

- Survey data for population variables such as age, weight, and daily water intake are available for these age groups.

- Toxicological variables are similar within these age groups, including responsiveness of sensitive subgroups (infants and children) to the contaminants of concern, toxicant intake to body weight ratios, and toxicokinetics.

The incidence of type II (adult onset) diabetes in Navajos is approximately 20 percent in the population over $20 \mathrm{yr}$ old and appears to be increasing (Hoy, 1993). Compromised renal function and increased drinking water ingestion rates in this diabetic subpopulation could increase susceptibility to toxicants. Though insufficient data exist to allow this risk assessment to quantitatively evaluate risk to diabetics, it is recognized that this group could represent a sensitive subpopulation.

\subsection{EXPOSURE PATHWAYS}

Groundwater use in the region is primarily for household purposes such as drinking, cooking, and bathing. Other uses typical of the region that could indirectly lead to human exposure include irrigation and livestock watering. Figure 4.1 provides a conceptual model for potential groundwater exposure pathways that could result from these uses. 







\subsubsection{Drinking water ingestion}

Drinking water ingestion is generally the most significant exposure pathway for groundwater contaminated with metals and other nonvolatile compounds. For this evaluation, drinking water consumption includes water consumed for drinking as well as water used for food preparation (e.g., reconstituted juices, soup, rice, and beans). For comparison of relative pathway significance, a screening level assessment of drinking water intake is shown in Table 4.1. These calculations are based on conservative estimates of the average concentrations of contaminants within the plume li.e., the 95-percent upper confidence limit (UCL) for the average concentration, using data from the most contaminated plume wells, well 606 for nitrate, and well 655 for all other contaminants].

\subsubsection{Dermal absorption}

Dermal absorption is the process by which chemicals coming into contact with the skin are absorbed into the blood vessels near the surface of the skin. Some compounds are absorbed easily in this manner, though metals do not possess the chemical properties that are conducive to skin absorption.

To evaluate this exposure route, a screening calculation was performed to determine if a dermal absorption pathway would be significant compared to the drinking water pathway for the contaminants of concern. Since chemical-specific absorption factors are not available for these contaminants, it was assumed that they are absorbed across the skin at the same rate as water. This assumption will probably overestimate any potential contribution from dermal absorption.

The results of the screening are given in Table 4.1. Based on these results, dermal absorption was eliminated from more detailed evaluation at this time because it contributed less than 1 percent of the total intake from drinking water.

\subsubsection{Ingestion of groundwater-irrigated produce}

This exposure route was also evaluated for its relative significance to the drinking water ingestion route. The results of the screening calculation are shown in Table 4.2. The assumptions for this evaluation will probably overestimate the potential for exposure from this route, because it is assumed that this garden would be the source of all garden produce in the diet. The results of this screening show that for the contaminants of potential concern at this site, ingesting garden vegetables and fruit irrigated with contaminated groundwater would lead to potential exposures of 1 percent or less of that associated with drinking water ingestion, except for strontium where as much as 15 percent of the groundwater ingestion dose could be obtained from ingesting irrigated plant materials. This pathway is eliminated from further 
Table 4.1 Exposure dose calculations and equation definitions for groundwater usage in future hypothetical adult scenarios, Monument Valley UMTRA Project site. Monument Valley, Arizona

\begin{tabular}{|c|c|c|c|c|}
\hline \multirow[b]{2}{*}{$\begin{array}{c}\text { Contaminant of } \\
\text { concern }\end{array}$} & \multirow[b]{2}{*}{$\underset{(\mathrm{mg} / \mathrm{L})}{\mathrm{Cw}}$} & \multicolumn{2}{|c|}{$\begin{array}{c}\text { Groundwater exposure doses } \\
\text { (mg/kg/day) }\end{array}$} & \multirow[b]{2}{*}{$\frac{\text { Dermal absorotion }}{\text { ingestion }}$} \\
\hline & & Ingestion & $\begin{array}{l}\text { Dermal } \\
\text { absorption }\end{array}$ & \\
\hline \multicolumn{5}{|l|}{ Noncancer effects } \\
\hline Nitrate & 1200 & $\begin{array}{c}3 E+01 \\
(9 E+01)^{a}\end{array}$ & $6 E-02$ & 0.002 \\
\hline $\begin{array}{l}\text { Strontium } \\
\text { Sulfate } \\
\text { Uranium } \\
\text { Vanadium }\end{array}$ & $\begin{array}{c}3.1 \\
2920 \\
0.029 \\
0.02\end{array}$ & $\begin{array}{c}8 E-02 \\
8 E+01 \\
8 E-04 \\
5 E-04\end{array}$ & $\begin{array}{l}2 E-04 \\
2 E-01 \\
2 E-06 \\
1 E-06\end{array}$ & $\begin{array}{l}0.002 \\
0.002 \\
0.002 \\
0.002\end{array}$ \\
\hline $\begin{array}{c}\text { Cancer effects } \\
\text { Uranium }\end{array}$ & $20^{b}$ & $7 E+05^{C}$ & $1 E+03^{c}$ & 0.002 \\
\hline
\end{tabular}

Equation Definitions for Exposure Dose Calculations

Ingestion of groundwater - carcinogens and noncarcinogcis:

$\begin{array}{ll}\text { Chronic daily intake }(\mathrm{mg} / \mathrm{kg} / \text { day }) & =\frac{\mathrm{Cw} \times \mathrm{IRw} \times \mathrm{EF} \times \mathrm{ED}}{B W \times A T} \\ \text { Radionuclides }(\mathrm{pCi}) & =\mathrm{Cw} \times \mathrm{IRw} \times \mathrm{EF} \times \mathrm{ED}\end{array}$

Dermal contact with groundwater - carcinogens and noncarcinogens:

Chronic daily intake $(\mathrm{mg} / \mathrm{kg} / \mathrm{day})$

$(C w \times S A \times P C \times C f) \times E T \times E F \times E D$

Radionuclides (pCi)

BW $\times$ AT

Where:

$C_{w}=$ Contaminant concentration in groundwater (upper $95 \%$ confidence level of the mean of data from plume wells).

$I R w=\quad$ Ingestion rate for water (L/day) $(2 \mathrm{~L} /$ day for an adult; $0.33 \mathrm{~L} /$ day for an infant).

$E F=$ Exposure frequency (350 days/yr).

$E D=$ Exposure duration (7 years for an adult; $1 \mathrm{yr}$ for an infant).

$B W=$ Body weight (70 kg for an adult; $4 \mathrm{~kg}$ for an infant).

$A T=$ Averaging time $(365$ days $\times$ ED for noncarcinogens; 365 days $\times 70 \mathrm{yr}$ for carcinogens).

$S A=$ Skin surface area $\left[19,400\right.$ square centimeters $\left.\left(\mathrm{cm}^{2}\right)\right]$.

$\mathrm{Pc}=$ Dermal permeability constant $(0.001 \mathrm{~cm} /$ hour $)$.

Cf $=$ Conversion factor $\left(0.001 \mathrm{~L} / \mathrm{cm}^{3}\right)$.

$E T=$ Exposure time (0.2 hour/day).

axposure dose calculated for an infant laged 0 to $1 \mathrm{yr}$ ).

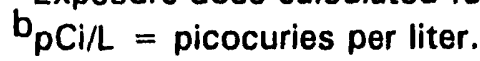

$\mathrm{c}_{\mathrm{pCi} \text { /lifetime. }}$ 
Table 4.2 Exposure dose calculations and equation definitions for groundwater-irrigated produce ingestion in future hypotentical adult scenarios, Monument Valley UMTRA Project site, Monument Valley, Arizona

\begin{tabular}{|c|c|c|c|c|c|c|c|}
\hline \multirow[b]{2}{*}{$\begin{array}{l}\text { Contaminant } \\
\text { of concern }\end{array}$} & \multirow[b]{2}{*}{$\underset{(m g / L)}{C w}$} & \multirow[b]{2}{*}{$\begin{array}{c}\text { Kd } \\
(L / k g)\end{array}$} & \multirow[b]{2}{*}{ Bv } & \multirow[b]{2}{*}{ Br } & \multicolumn{2}{|c|}{$\begin{array}{l}\text { Garden produce ingestion } \\
\text { exposure doses }(\mathrm{mg} / \mathrm{kg} / \text { day) }\end{array}$} & \multirow{2}{*}{$\begin{array}{c}\text { Total } \\
\text { produce } \\
\text { ingestion } \\
\text { water } \\
\text { ingestion }\end{array}$} \\
\hline & & & & & $\begin{array}{l}\text { Vegetative } \\
\text { parts }\end{array}$ & $\begin{array}{l}\text { Reproductive } \\
\text { parts }\end{array}$ & \\
\hline \multicolumn{8}{|c|}{ Noncancer effects } \\
\hline Nitrate & 1200 & 0.01 & 30 & 30 & $2 E-02$ & $1 \mathrm{E}-02$ & 0.0008 \\
\hline Strontium & 3.1 & 35 & 2.5 & 0.25 & $1 \mathrm{E}-02$ & 7E-04 & 0.15 \\
\hline Sulfate & 2920 & 7.5 & 0.5 & 0.5 & 5E-01 & $3 E-01$ & 0.01 \\
\hline Uranium & 0.029 & 450 & 0.0085 & 0.004 & $5 E-06$ & 1E-06 & 0.008 \\
\hline Vanadium & 0.02 & 1000 & 0.0055 & 0.003 & $5 E-06$ & $2 E-06$ & 0.01 \\
\hline \multicolumn{8}{|l|}{ Cancer effects } \\
\hline Uranium $^{\mathbf{a}}$ & $20^{b}$ & 450 & 0.0085 & 0.004 & $4.36 E+03^{C}$ & $1.23 E+03^{C}$ & 0.008 \\
\hline
\end{tabular}

\section{Equation Definitions for Exposure Dose Calculations}

Ingestion of garden oroduce irrigated with around water - carcinogens and noncarcinogens:

Chronic daily intake $(\mathrm{mg} / \mathrm{kg} / \mathrm{day})=\frac{\mathrm{CW} \times \mathrm{Kd} \times \mathrm{BV} \text { or } \mathrm{Br}{ }^{*} \times \mathrm{DF} \times \operatorname{Rp} \times \mathrm{FI} \times \mathrm{EF} \times \mathrm{ED}}{\mathrm{BW} \times \mathrm{AT}}$

Radionuclides $(\mathrm{pCi}) \quad=\quad \mathrm{Cw} \times \mathrm{Kd} \times \mathrm{Bv}$ or $\mathrm{Br}^{*} \times \mathrm{DF} \times \operatorname{IRp} \times \mathrm{F} / \times \mathrm{EF} \times \mathrm{ED}$ Where:

$\mathrm{Cw}_{w}=$ Contaminant concentration in groundwater lupper $95 \%$ confidence level of the mean of data from plume wells).

Kd = Soil-water partition coefficient (L/kg).

Bv = Soil-to-plant concentration ratio for vegetative portions of plarits (unitless).

$\mathrm{Br}=$ Soil-to-plant concentration ratio for reproductive portions (fruits, tubers) of plants (unitless).

$\mathrm{EF}=$ Exposure frequency $(350$ days/yr).

$E D=$ Exposure duration ( $7 \mathrm{yr}$ for an adult; $1 \mathrm{yr}$ for an infant).

BW = Body weight ( $70 \mathrm{~kg}$ for an adult; $4 \mathrm{~kg}$ for an infant).

AT = Averaging time (365 days $\times$ ED for noncarcinogens; 365 days $\times 70 \mathrm{yr}$ for carcinogens).

- $=$ Exposure doses due to vegetative portions and reproductive portions of garden produce are calculated separately.

DF = Dry weight fraction of plant (unitless) 0.066 .

IRp = Ingestion rate for garden produce $10.05 \mathrm{~kg} /$ day for vegetative parts; $0.03 \mathrm{~kg} / \mathrm{day}$ for reproductive parts).

$\mathrm{FI}=$ Fraction of garden produce ingested from contaminated source (1.0 unitless).

\footnotetext{
aUranium-234 and -238.

$b_{p C i / L}$.

$\mathrm{c}_{\mathrm{pCi}}$ /lifetime.
} 
evaluation, although the potential increment of strontium to drinking water exposure is discussed in Section 6.1.

\subsubsection{Ingestion of meat or milk from groundwater-fed livestock}

These pathways were eliminated from further consideration, because the concentrations of nitrate and sulfate are so high that livestock could not survive chronic ingestion of the water. If the livestock cannot consume the water, there is no potential for bioaccumulation or transfer of contaminants ingested to meat tissue or milk. In addition, infants aged 0 to 3 months (the population most sensitive to nitrate toxicity) do not consume meat or dairy products. Further evaluation of the direct toxicity to livestock is presented in Section 7.0.

The results of the pathway screening analyses indicate drinking water ingestion is the dominant pathway; this pathway is further evaluated probabilistically in Section 4.4.

\subsection{EXPOSURE CONCENTRATIONS}

Exposure concentration of a contaminant in groundwater is defined as the concentration an individual is assumed to take in over a specific period. In this evaluation, the contaminant concentrations are assumed to be in a steady state although actual contaminant concentrations (and therefore exposures) are expected to decrease with time, after the tailings are removed. Nonetheless, these estimates are reasonable for chronic exposure soon after surface remediation. (Chronic exposure for noncarcinogens is considered to be exposure for any period longer than $7 \mathrm{yr}$.)

Exposure concentrations are evaluated as a probability of occurrence based on groundwater data collected from monitor well 655 for strontium, sulfate, uranium, and vanadium. This well has consistently shown the highest concentrations of these constituents since 1988. Because nitrate levels in well 606 were greater than in 655 , well 606 was used to model nitrate exposures.

The probability distribution selected for each contaminant reflected the same mean, median, standard deviation, and shape as were observed in historical water quality data. The upper tail of the distributions was truncated at the 99th percentile. For every contaminant, this highest allowable concentration was higher than the maximum observed concentration in the historical water quality data. The software package @RISK (Palisade Corp, Newfield, New York) was used to generate the contaminants of concern probability curves. The results are shown in Figures 4.2 through 4.6.

\subsection{ESTIMATION OF INTAKE}

Within the population of future residents, individuals are expected to vary with respect to water consumption habits, stable body weight, and length of time they reside in the potential contamination zone. Consequently, health risks 




FIGURE 4.2

SIMULATED DISTRIBUTION OF NITRATE BASED ON DATA FROM WELL 606

MONUMENT VALLEY, ARIZONA, STTE 


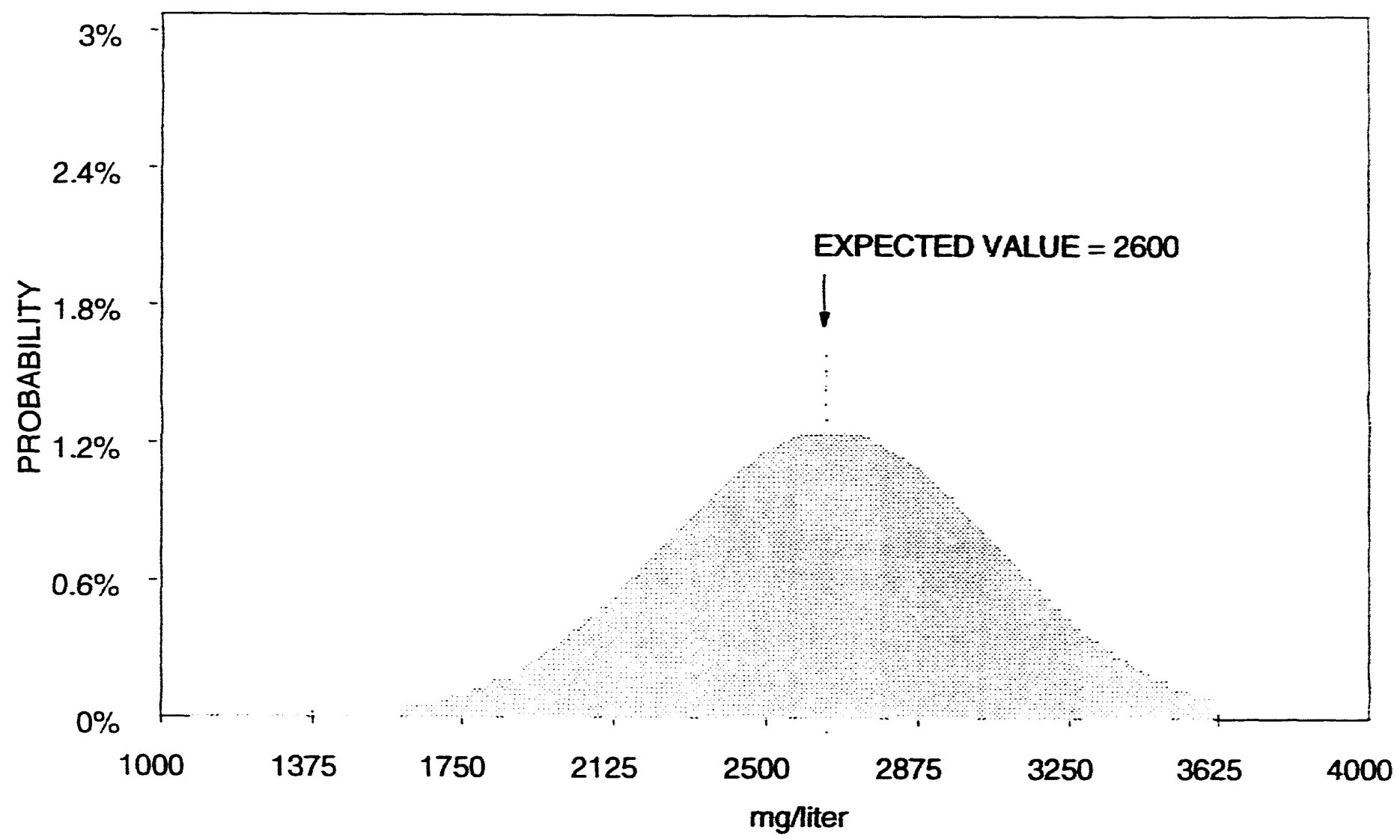

FIGURE 4.3

SIMULATED DISTRIBUTION OF SULFATE BASED ON DATA FROM WELL 655

MONUMENT VALLEY, ARIZONA, STTE 


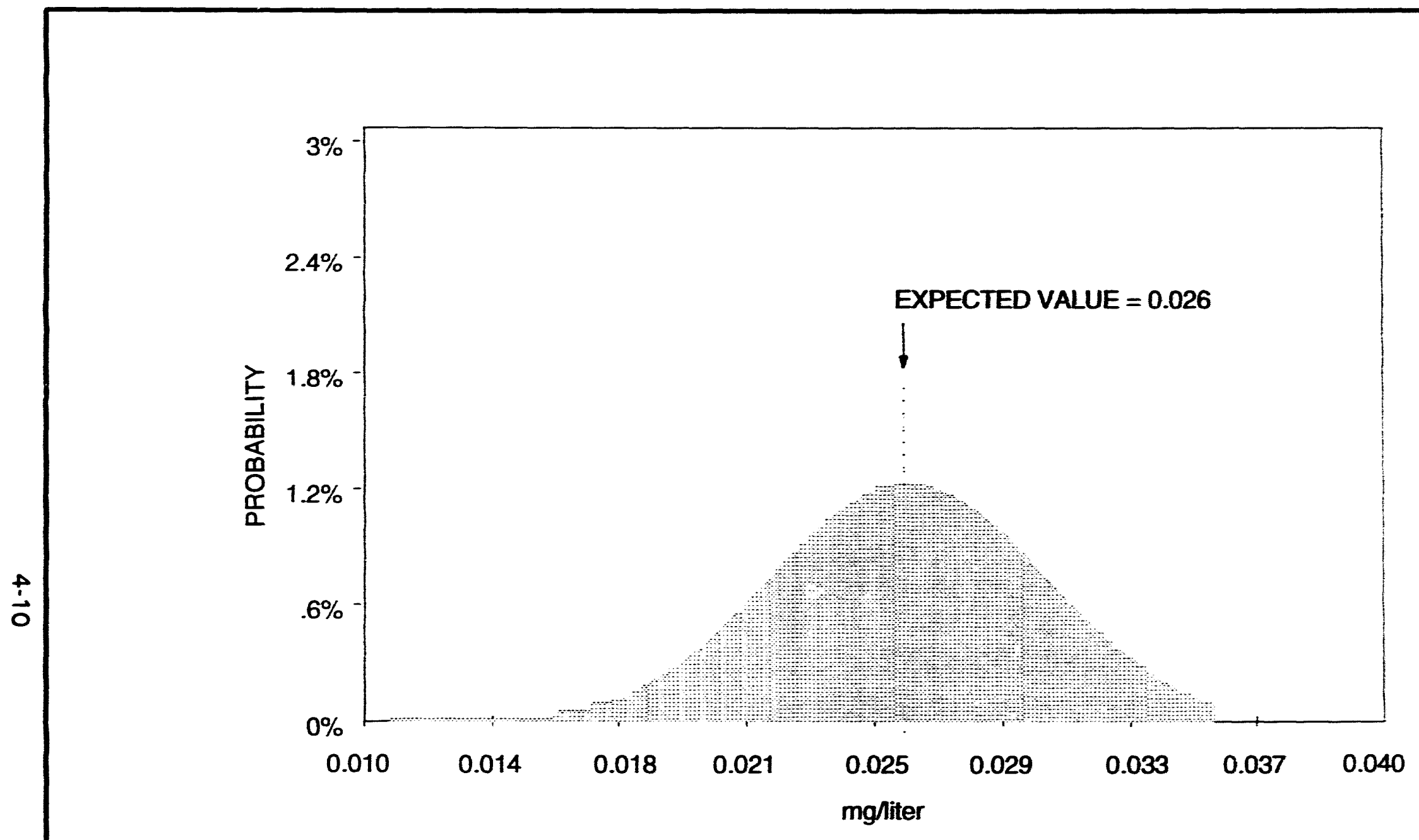

FIGURE 4.5

SIMULATED DISTRIBUTION OF URANIUM BASED ON DATA FROM WELL 655 MONUMENT VALLEY, ARIZONA, STIE 


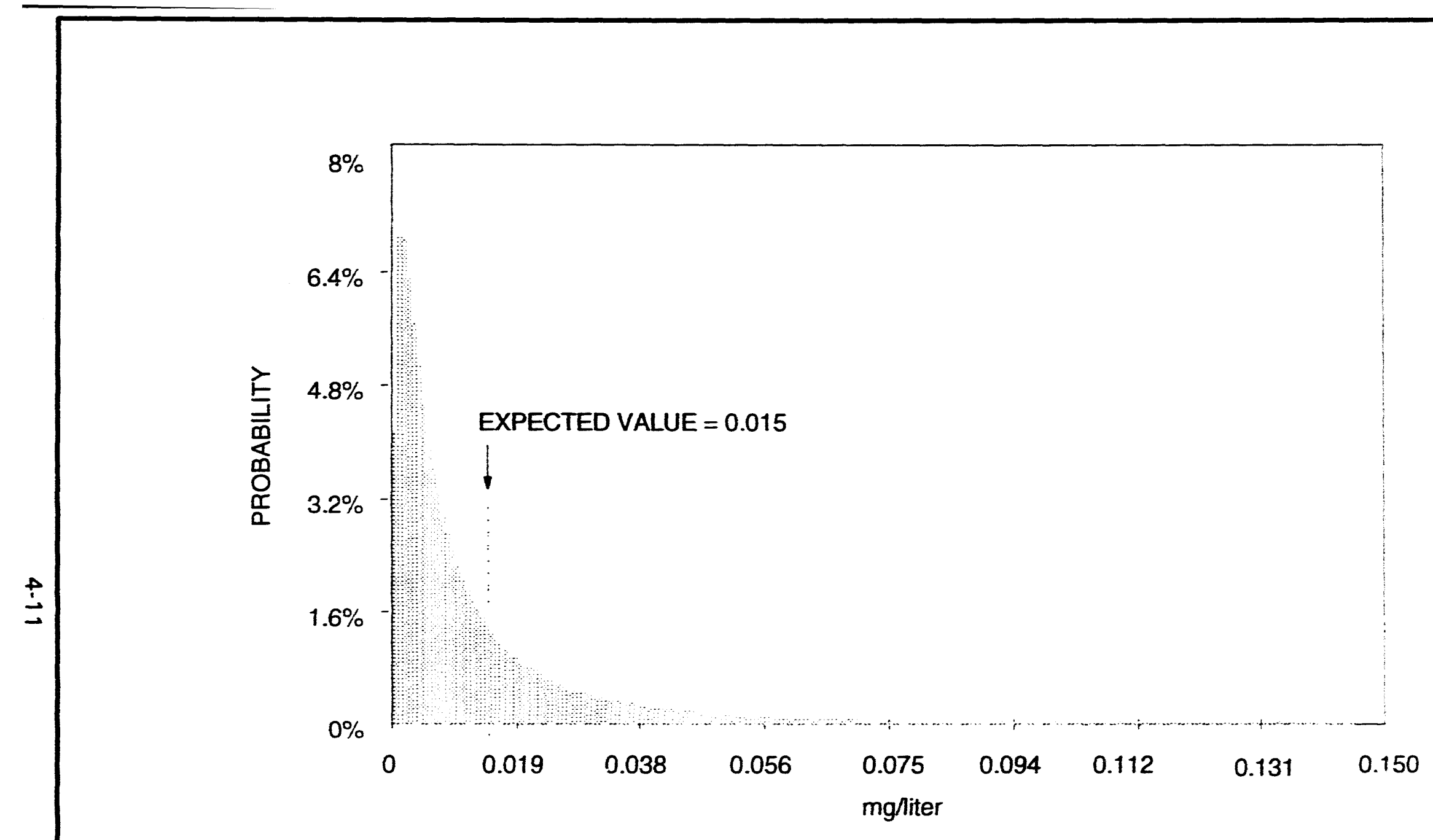

FIGURE 4.6

SIMULATED DISTRIBUTION OF VANADIUM BASED ON DATA FROM WELL 655

MONUMENT VALLEY, ARIZONA, SITE 
associated with groundwater consumption will vary among members of this population. To adequately describe the range of potential risks to the future population, naturally occurring variability in daily water intake, body weight, and residency time were incorporated in this assessment through probability distributions; these distributions were generated from United States public health and census documents. All distributions were truncated at the upper and lower 0.01 percentile. Within the hypothetical population, values disallowed through this truncation may occur with a probability of less than 1 in 10,000.

The potential toxicity of noncarcinogenic contaminants in drinking water depends primarily on long-term average daily consumption of the contaminant per kilogram of body weight. For noncarcinogens, exposure frequency multiplied by exposure duration cancels out with averaging time. Therefore, these factors are omitted from the equation and chronic daily intake is calculated as follows:

$$
\text { Intake }(\mathrm{mg} / \mathrm{kg} / \text { day })=\frac{\text { Concentration }(\mathrm{mg} / \mathrm{L}) \times \text { ingestion rate }(\mathrm{L} / \text { day })}{\text { Body weight }(\mathrm{kg})} \text {. }
$$

Potential carcinogenicity is thought to increase with total intake over time, instead of with average daily intake as for noncarcinogens. Also, body weight is relatively insignificant in determining risk from exposure. Because the only carcinogen elevated above background at the Monument Valley site is uranium, only uranium ingestion will be presented here. Intake of a radioactive carcinogenic substance is therefore quantified as total exposure to radioactivity throughout the residency period of an individual:

$$
\underset{(\mathrm{pCi})}{\text { Intake }}=\underset{(\mathrm{pCi} / \mathrm{L})}{\text { Concentration }} \times \underset{(\mathrm{L} / \text { day })}{\mathrm{ingestion} \text { rate }} \times \underset{\text { (days) }}{\text { exposure duration. }}
$$

\section{Average daily intake (L/day)}

Lognormal probability distributions were used to describe variation in average daily tap water intake among members of the population (Roseberry and Burmaster, 1992). These distributions were developed from data collected during the 1977-78 National Food Consumption Survey conducted by the U.S. Department of Agriculture. During the survey, total tap water consumption during a 3-day period was recorded for 26,081 survey participants nationwide (Figure 4.7).

\section{Body weight $(\mathrm{kg})$}

Extensive national data on weights of males and females, by age, were collected by the National Health and Nuirition Survey between 1976 and 1980 . These data were used to develop lognormal probability distributions for body weight by age, separately by gender. The distributions for males and females were then combined using census data on the national ratio of males to females within each age group (Figure 4.8). 

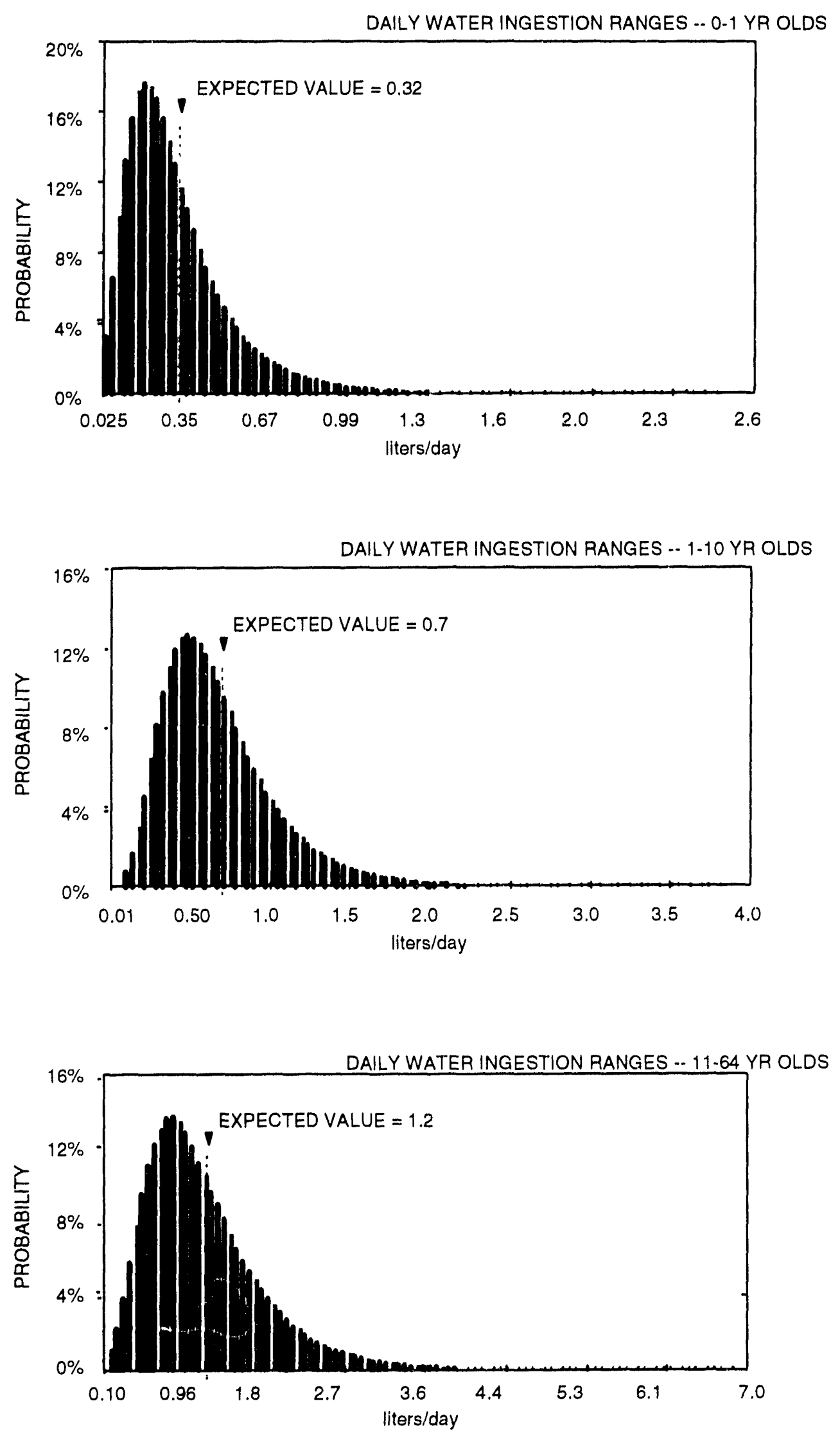

FIGURE 4.7

PROBABILITY DISTRIBUTIONS FOR TAP WATER INGESTION RATES BY AGE GROUP 


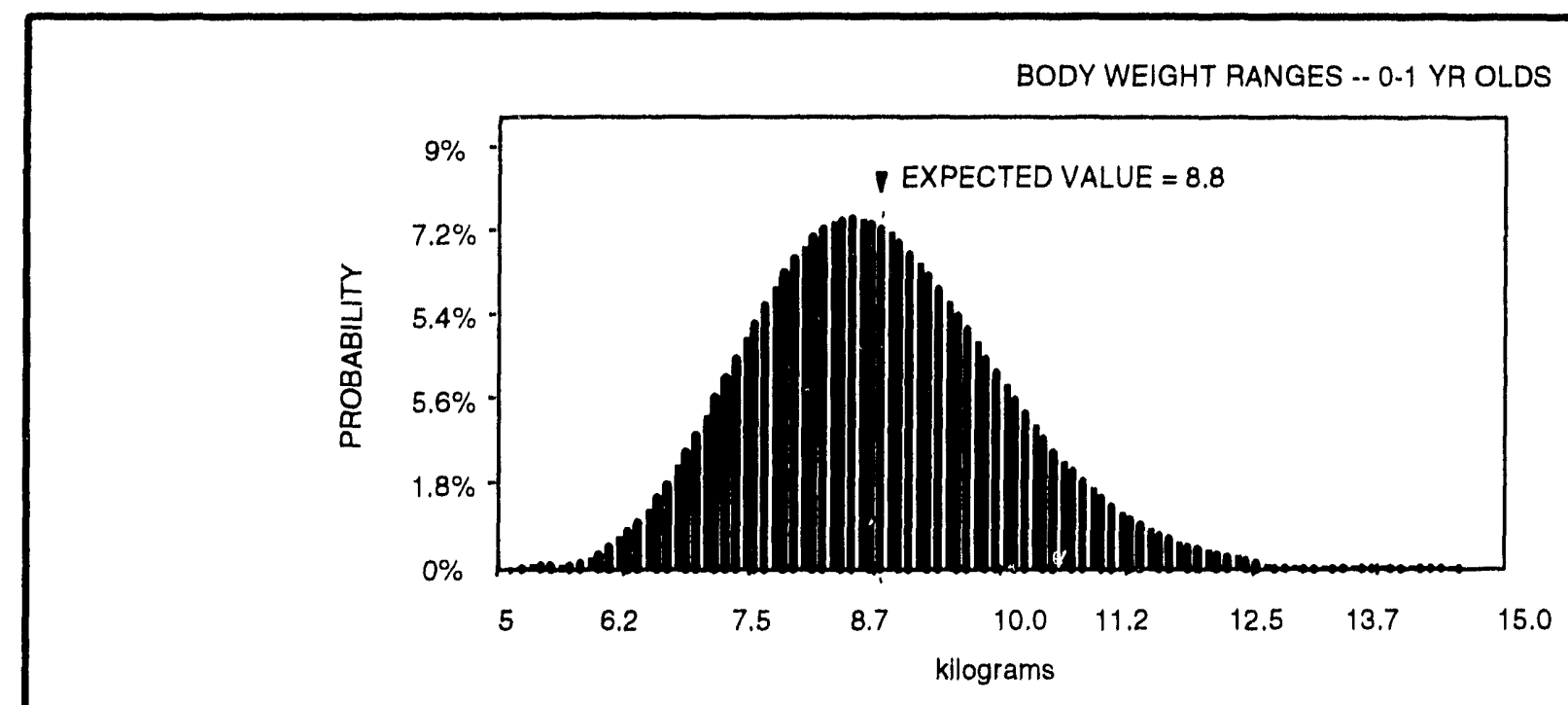

BODY WEIGHT RANGES .- $1 \cdot 10$ YR OLDS

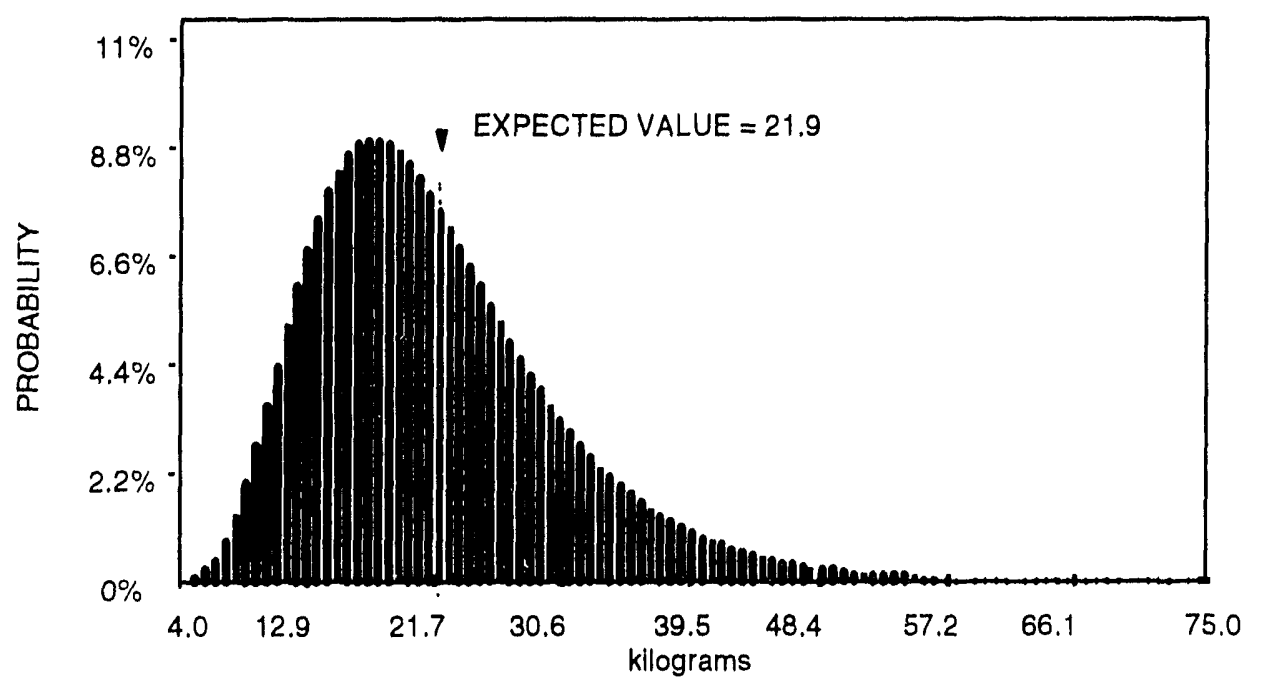

BODY WEIGHT RANGES -- 11-64 YR OLDS

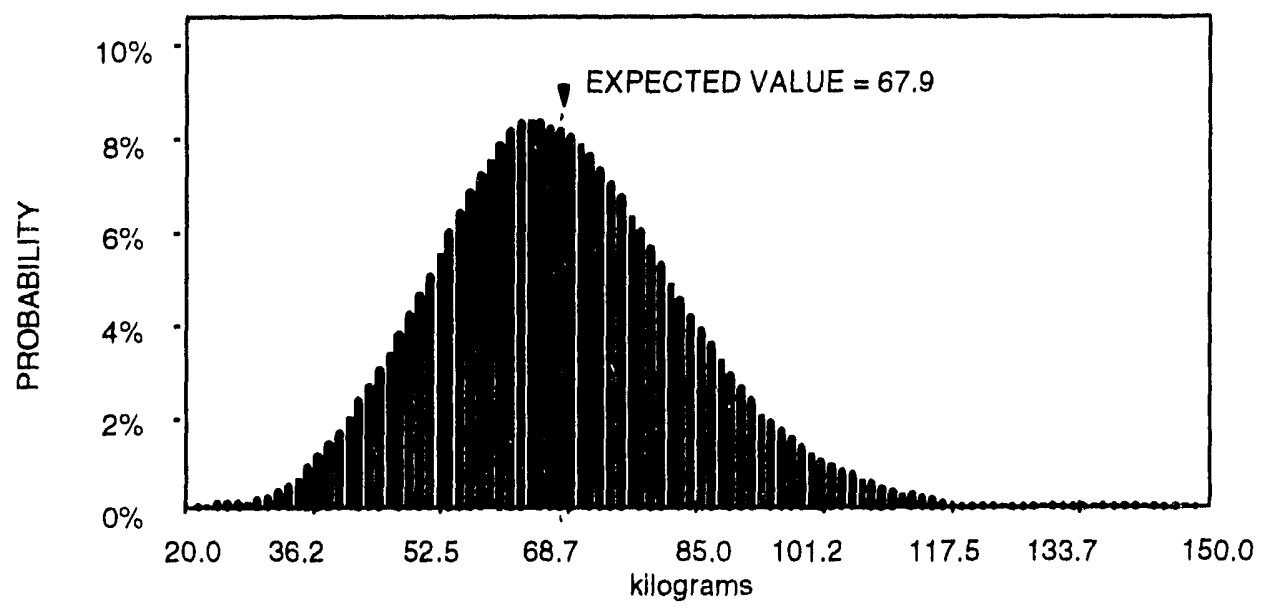

FIGURE 4.8

PROBABILITY DISTRIBUTIONS FOR BODY WEIGHT BY AGE GROUP 


\section{Exposure duration (years)}

For noncarcinogen effects, the exposure duration and the averaging time of the drinking water intake (see equations in Tables 4.1 and 4.2) cancel out, assuming all exposures are chronic, i.e., $\geq 7 \mathrm{yr}$. Therefore, deviation from the standard residence time assumptions do not affect the results. For carcinogens, however, because risk is cumulative throughout a lifetime, deviations from the hypothesized distribution could significantly affect the risk estimate. Because of the grazing permit system used by the Navajo nation for land allocation, residents can frequently be in the same region for an entire lifetime. No available data adequately model this longer residence time. Therefore, a fixed lifetime exposure time of $70 \mathrm{yr}$ was used to model lifetime cancer risks.

Using exposure concentration distributions discussed in Section 4.3 and the intake parameter distributions described in this section, total intake distributions derived for the three age groups were generated for sulfate. These results are presented in Figure 4.9 to illustrate the effect of the different age group characterization on daily intake of noncarcinogens. From this figure, it can be seen that intake is greatest in the 1- to 10-yr age group. Therefore, that group is used in risk evaluation unless one of the other age groups has demonstrated increased sensitivity to a particular constituent. Of the contaminants at Monument Valley, nitrate is the only contaminant for which a sensitive subpopulation is known. Therefore, the nitrate exposure risk determinations are based on infant exposure. Simulated intake distributions for appropriate age groups for the nitrate and remaining contaminants are presented in Figures 4.10 through 4.13 .

\subsection{EXPOSURE ASSESSMENT UNCERTAINTIES}

A number of potential sources of error may arise in all phases of the exposure assessment, including the following more significant sources of uncertainty:

- Uncertainties resulting from the lack of thorough environmental sampling (groundwater and surface water) data, which could lead to an underestimate or overestimate in the exposure analysis.

- Uncertainties arising from the assumption that the groundwater contaminant source term at the site has reached a steady state and that contaminant concentrations at the exposure point will remain constant for chronic periods of exposure (generally greater than $7 \mathrm{yr}$ ). Because the source of contamination at Monument Valley has been removed, the assumption of a constant source will probably lead to an overestimation of risk.

- Uncertainties associated with the model used to estimate uptake of contaminants into plants for the irrigated garden produce pathway. Under the site conditions at Monument Valley, plant uptake factors could vary substantially from the default literature estimates. As with environmental sampling, the net effect on risk estimates of this uncertainty cannot be predicted. 

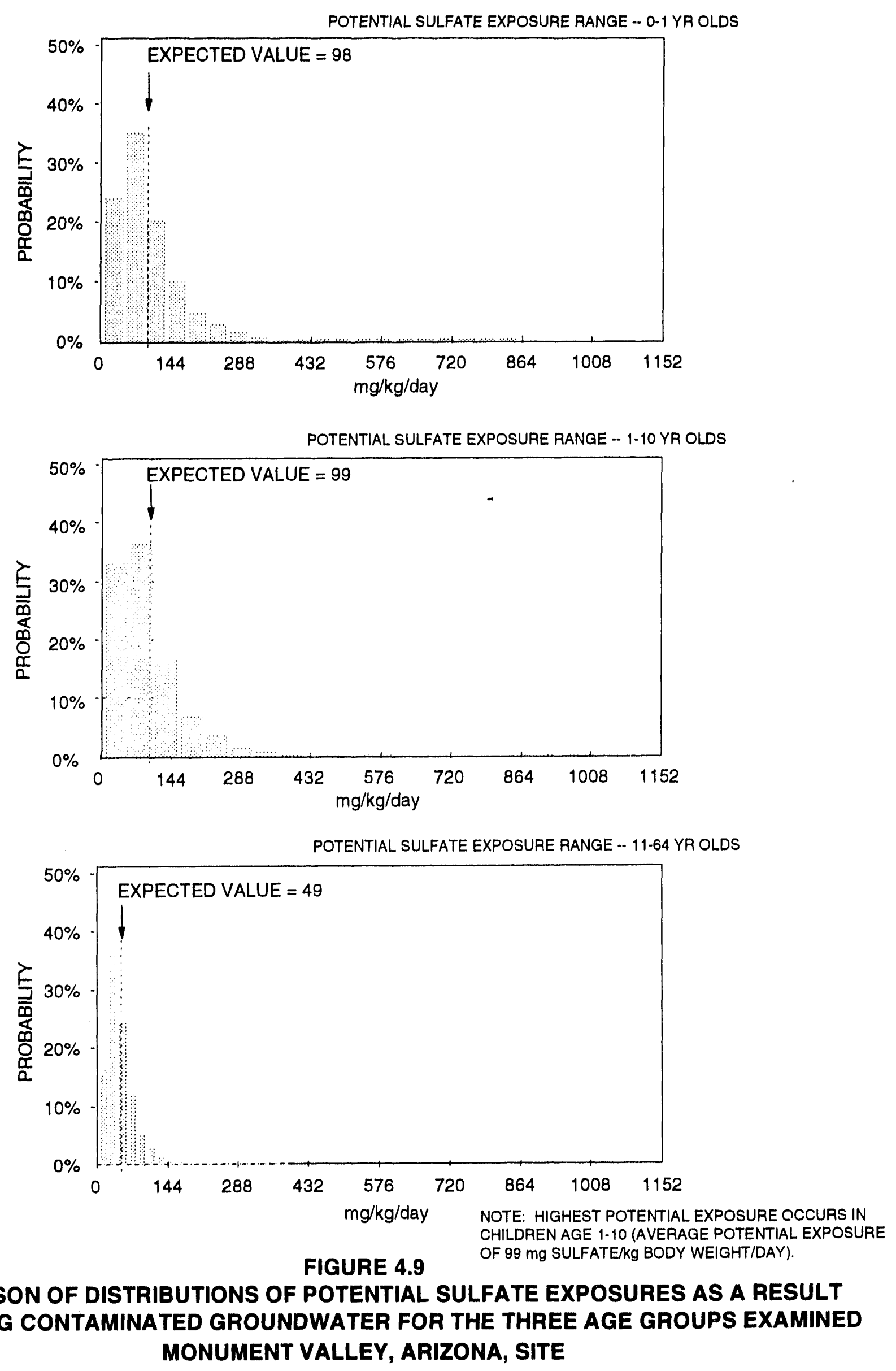


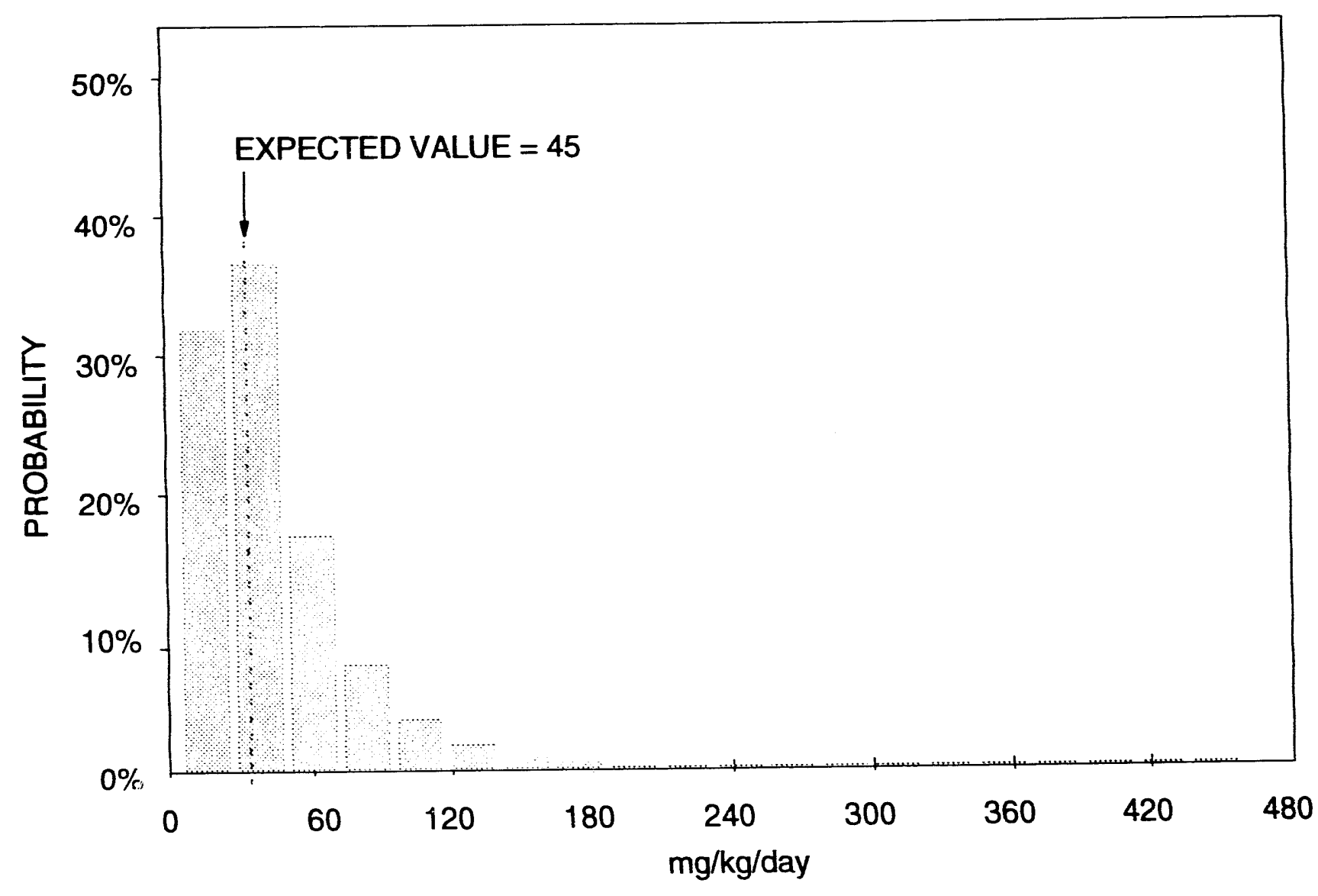

NOTE: AVERAGE POTENTIAL EXPOSURE IS 45 mg NITRATE/ kg BODY WEIGHTIDAY. INFANTS' EXPCSURES HAVE BEEN MODELED FOR NITRATE BECAUSE INFANTSS ARE MORE SENSITIVE TO NITRATE TOXICITY THAN THE OTHER TWO AGE GROUPS.

FIGURE 4.10

DISTRIBUTION OF POTENTIAL NITRATE EXPOSURES FOR INFANTS CONSUMING CONTAMINATED GROUNDWATER MONUMENT VALLEY, ARIZONA, SITE 


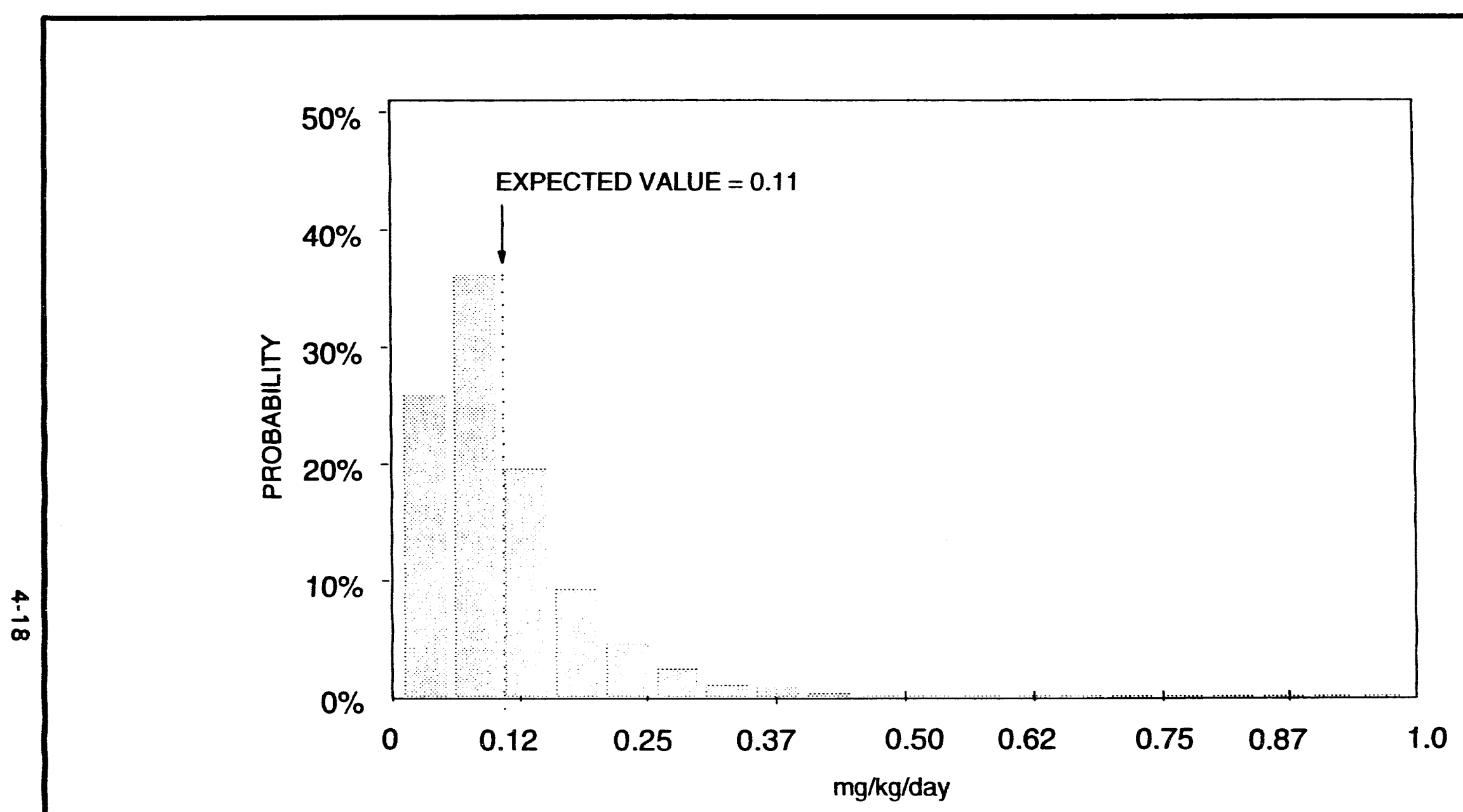

NOTE: AVERAGE POTENTIAL EXPOSURE IS $0.11 \mathrm{mg}$ STRONTIUM/ $\mathrm{kg}$ BODY WEIGHTIDAY. EXPOSURES FOR CHILDREN HAVE BEEN MODELED BECAUSE THEIR INTAKE/kg BODY WEIGHT IS GREATEST AND NO SENSITIVE POPULATION HAS BEEN IDENTIFIED.

FIGURE 4.11

DISTRIBUTION OF POTENTIAL STRONTIUM EXPOSURES FOR CHILDREN

AS A RESULT OF CONTAMINATED GROUNDWATER INGESTION MONUMENT VALLEY, ARIZONA, SITE 


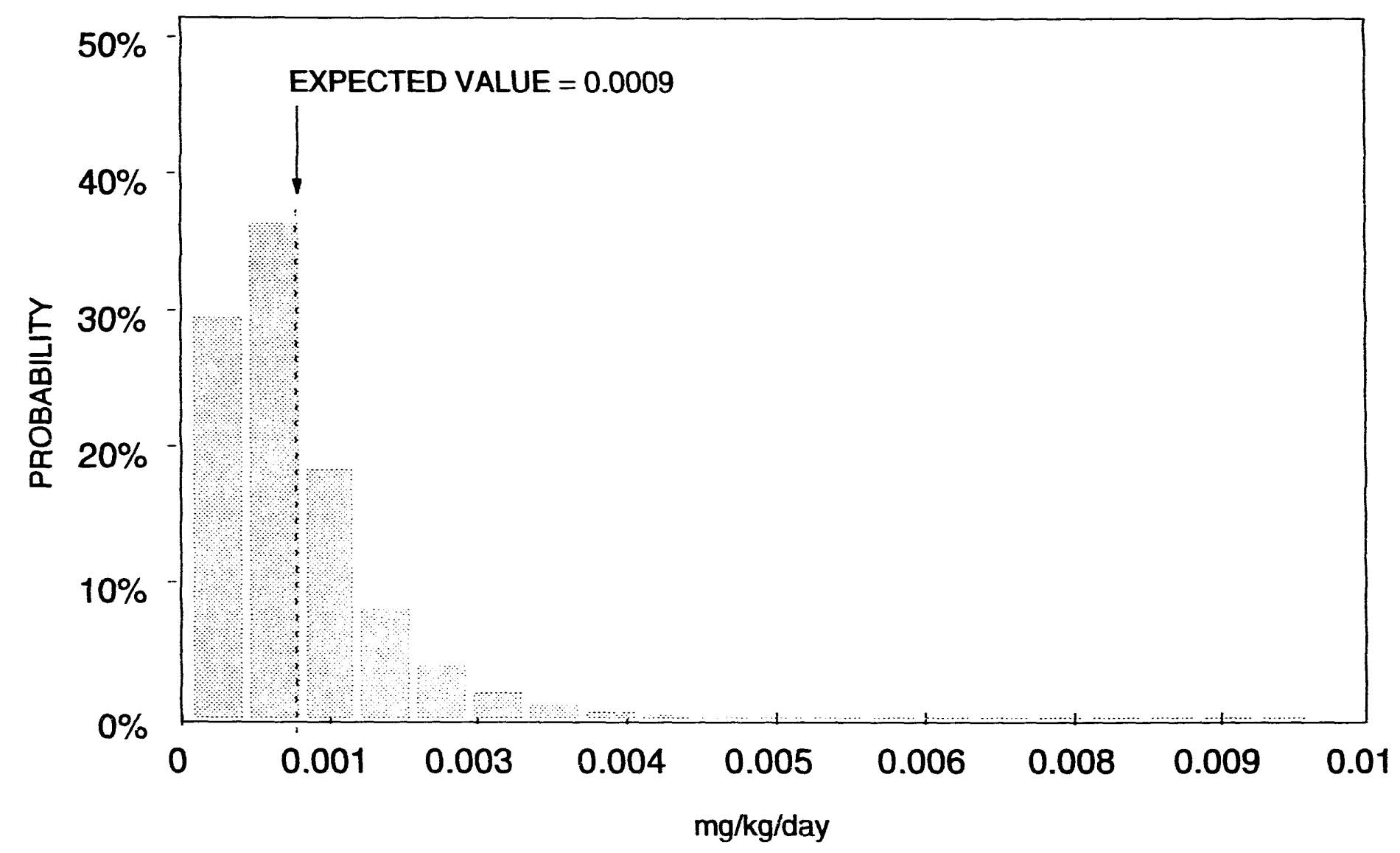

NOTE: AVERAGE POTENTIAL EXPOSURE IS $0.0009 \mathrm{mg}$ URANIUM/ $\mathrm{kg}$ BODY WEIGHTIDAY. EXPOSURES FOR CHILDREN HAVE BEEN MODELED BECAUSE THEIR INTAKE/kg BODY WEIGHT IS GREATEST AND NO SENSITIVE POPULATION HAS BEEN IDENTIFIED.

FIGURE 4.12

DISTRIBUTION OF POTENTIAL URANIUM EXPOSURES FOR CHILDREN

AS A RESULT OF CONTAMINATED GROUNDWATER INGESTION MONUMENT VALLEY, ARIZONA, SITE 


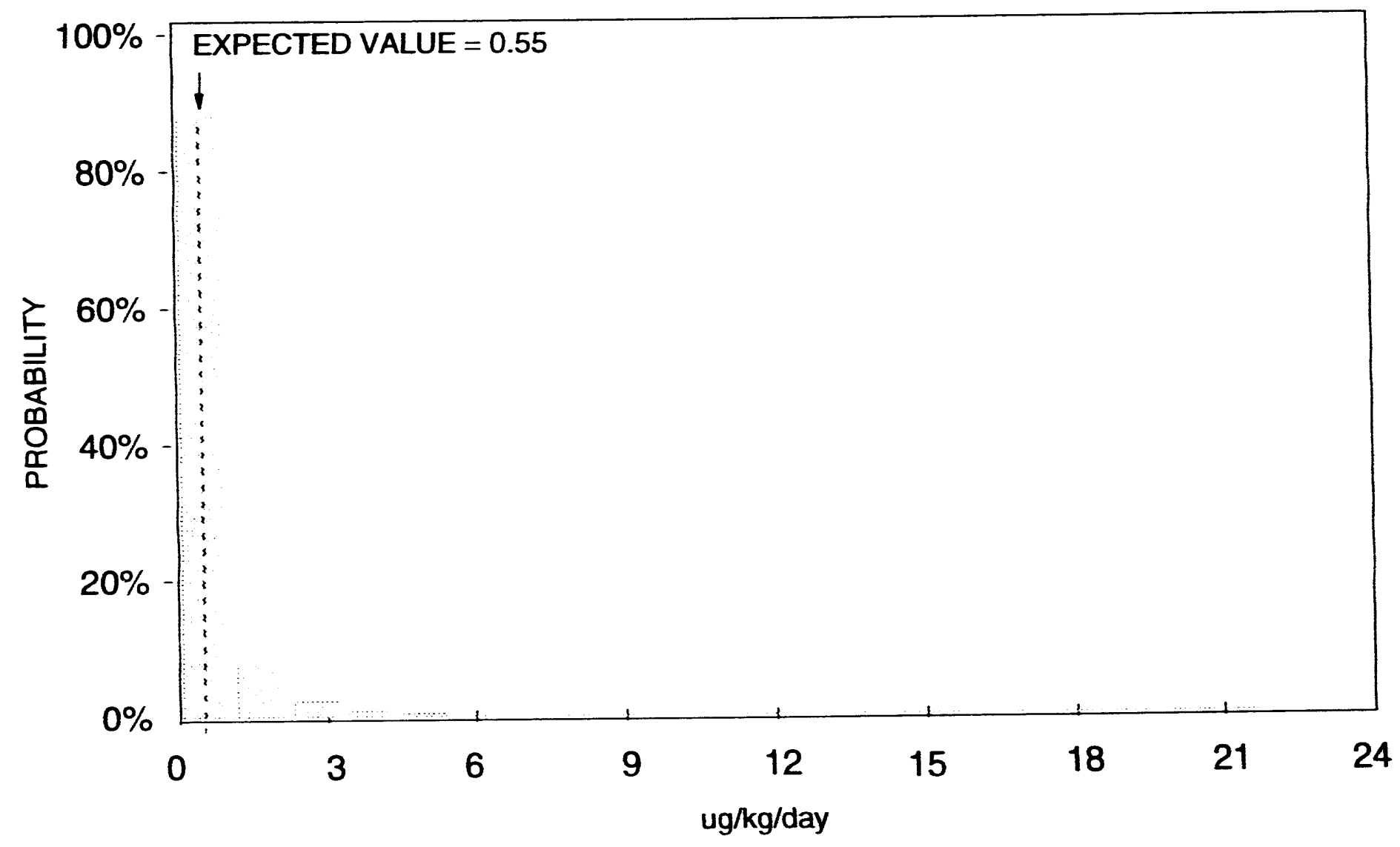

NOTE: AVERAGE POTENTIAL EXPOSURE IS 0.55 Ug VANADIUM $\mathrm{kg}$ BODY WEIGHTTDAY. EXPOSURES FOR CHILDREN HAVE BEEN MODELED BECAUSE THEIR INTAKE/kg BODY WEIGHT IS GREATEST AND NO SENSITIVE POPULATION HAS BEEN IDENTIFIED.

FIGURE 4.13

DISTRIBUTION OF POTENTIAL VANADIUM EXPOSURES FOR CHILDREN AS A RESULT OF CONTAMINATED GROUNDWATER INGESTION

MONUMENT VALLEY, ARIZONA, SITE 
- Uncertainties associated with the relationship of an applied dose (used here) and absorbed dose or effective toxic dose.

- Uncertainties associated with differing sensitivities of subpopulations such as diabetics.

Despite these uncertainties, the use of probability distributions that incorporate all definable sources of variability should provide a representative picture of the potential range of exposures. 


\subsection{TOXICITY ASSESSMENT}

As discussed in Section 3.0, five contaminants that could cause adverse human health and environmental effects have been detected in groundwater at the site: nitrate, strontium, sulfate, vanadium, and uranium. This section summarizes the toxicological effects of the chemical contaminants and carcinogenic potentials of the radionuclide uranium.

\subsection{CONTAMINANT TOXICITY SUMMARIES}

The basic toxicokinetics and toxicity of each of the five contaminants of concern at the Monument Valley site are summarized below. Wherever possible, data from human studies will be addressed. Only in cases where human data are unavailable will animal studies be reported. Although these contaminants have a wide range of toxic effects, depending on exposure level, the following discussions will focus on toxic effects observed in the exposure range most relevant to contamination in the area of the Monument Valley site.

\subsubsection{Nitrate}

\section{Absorption}

Ingested nitrate is converted in the gut to the toxic nitrite ion, which is readily absorbed. The conversion rate depends on both gut flora and $\mathrm{pH}$, with a more rapid conversion in a higher $\mathrm{pH}$ environment. Infants have a higher gut $\mathrm{pH}$, which is more conducive to growth of bacteria. Therefore, the combination of a higher $\mathrm{pH}$ and increased bacterial conversion increases the production of nitrite from nitrate in infants, resulting in higher blood nitrite levels for a given dose of nitrate. In healthy adults, nitrates are rapidly absorbed from the upper intestine. This rapid absorption reduces the contact time with gut flora, thereby reducing the conversion to nitrite and the resultant toxicity.

\section{Tissue accumulation and clearance}

After absorption, the nitrite ion binds to hemoglobin in the blood and oxidizes it, thereby both lowering the oxygen-carrying capacity of the blood and decreasing the rate of oxygen release. The oxidized hemoglobin is called methemoglobin and can be reduced back to normal hemoglobin enzymatically by methemoglobin reductase. Infants are more sensitive to these effects because of the presence of fetal hemoglobin, which is more sensitive to oxidation by nitrite, and because their lower activity of methemoglobin reductase means the methemoglobin remains oxidized for a longer period. Some individuals with a rare genetic deficiency in methemoglobin reductase exhibit higher levels of circulating methemoglobin. Although they develop alternate metabolic pathways to maintain adequate levels of circulating hemoglobin in the normal state, exposure to high levels of nitrate can lesult in excessive levels of methemoglobin in these people. 
In healthy adults, the half-time for methemoglobin reductase conversion of methemoglobin back to hemoglobin is estimated to range from 6 to $24 \mathrm{hr}$ for theoretical levels of methemoglobin in the 80 to 100 percent range (Bolyal et al., 1972).

\section{Environmental sources of nitrate}

Nitrates accumulate in soils from the application of fertilizers, human and animal waste, bacterial nitrogen fixation, mineral dissolution, and plant and animal tissue breakdown. These nitrates can filter through the soil into groundwater. Nitrate concentrations in well water have been reported to exceed $440 \mathrm{mg} / \mathrm{L}$, or 10 times the current regulatory levels (Lee, 1970).

Bloaccumulation of nitrates from soil and water to plants results in a wide range of nitrate concentrations in fresh fruits and vegetables, with levels as high as 2000 milligrams per kilogram $(\mathrm{mg} / \mathrm{kg}$ ) of body weight reported in beets and $9000 \mathrm{mg} / \mathrm{kg}$ in radishes (Kamm ot al., 1965; Smith, 1966). The accumulation of nitrates in plant material is increased by factors such as drought, high temperatures, cloudiness, and insect and herbicide damage to plants. Nitrates and nitrites are also used to preserve meats, especially corned or smoked products.

\section{Toxicity of nitrate}

The primary toxicity of nitrate is methemoglobinemia, which is a function of the balance between circulating levels of nitrite and methemoglobin reductase activity. A very high acute dose can produce the same toxicity as a lower dose that slowly increases the concentration of methemoglobin over time. Therefore, the acute and chronic toxicity of nitrate are summarized together. For easier comparison between ingested doses of nitrate and groundwater levels at Monument Valley, dose ranges are presented in terms of nitrate intake. The reader should be aware that nitrate exposure levels are frequently converted to the nitrogen concentration in the nitrate by dividing the nitrate number by 4.4 . Therefore, $44 \mathrm{mg} / \mathrm{L}$ nitrate is equivalent to $10 \mathrm{mg} / \mathrm{L}$ nitrate-nitrogen.

Symptoms of methemnglobiriemia can be correlated with the percentage of methemoglobin in the blood: With less than 10 percent methemoglobin, individuals are asymptomatic; more than 25 percent methemoglobin produces weakness, rapid pulse, and tachypnea (rapid breathing); more than 50 to 60 percent methemoglobin can be fatal (EPA, 1993). These symptoms reflect a progressive decrease in oxygen availability. As explained above, infants are more sensitive to the production of methemoglobin and therefore are considered the most sensitive population. The route of exposure for infants is from the use of contaminated water for formulia.

No symptoms of toxicity have been reported with nitrate intakes below $7 \mathrm{mg}$ of nitrate per kilogram of body weight per day $(\mathrm{mg} / \mathrm{kg} /$ day). As nitrate increases above this level in infants, mild symptoms such as weakness, rapid pulse, and 
rapid breathing occur with intakes from 7 to $30 \mathrm{mg} / \mathrm{kg} /$ day. The severity of these symptoms increases as increased nitrate intake results in greater levels of methemoglobin and therefore reduced oxygen availability. Cyanosis, or a blue appearance to the skin, occurs, followed by unconsciousness as oxygen availability is further reduced. The lowest reported fatal dose of chronic nitrate is $35 \mathrm{mg} / \mathrm{kg} / \mathrm{day}$ for an infant and $116 \mathrm{mg} / \mathrm{kg}$ (acute intake) for an adult. A wide range of nitrate intake can produce similar symptoms among individuals because of net differences in gut $\mathrm{pH}$, bacterial activity, and methemoglobin reductase activity. The health effects of nitrates in infants are summarized as a function of dose in Figure 5.1.

Data on nitrate toxicity are primarily based on epidemiologic studies of human adults and infants who report to hospitals with symptoms of

methemoglobinemia. In most cases, exposure doses were back-calculated from sampling their drinking water. Therefore, these data do not represent well-controlled studies with readily defined dosage ranges. Many water sources in these clinical studies showed contamination with bacteria, leading to the possibility that this bacterial exposure is a necessary cofactor in the development of methemoglobinemia. One laboratory study indicated that healthy infants could drink nitrate at $24 \mathrm{mg} / \mathrm{kg} /$ day in solutions free of bacteria and show no symptoms of methemoglobinemia.

Gastrointestinal distress has also been suggested as a cofactor in the development of methemoglobinemia. Anecdotally, infants with colic are more susceptible to nitrate-induced methemoglobinemia.

\subsubsection{Strontlum}

The isotopes of strontium present at UMTRA Project sites are all natural, stable isotopes. The radioactive element strontium-90 is not naturally occurring and is produced only as a product of fission reactions. Therefore, no radiation exposures are associated with the presence of strontium at UMTRA Project sites.

\section{Absorption}

In humans, 14 to 50 percent of an orally administered dose of strontium is absorbed, with peak blood levels occurring within $4 \mathrm{hr}$. Absorption is proportional to dose, although large doses may overwhelm homeostatic inechanisms. Strontium is absorbed by passive diffusion from the intestinal lumen (Comar and Wasserman, 1964). Because of their chemical resemblance, strontium can effectively displace calcium. In cases of dietary calcium deficiency, strontium is absorbed to a higher degree. The bioavailability of ingested strontium is estimated to be 20 percent. This figure varies, depending on age, species, form of strontium, and dietary levels of phosphorus, vitamin $D$, and calcium. 


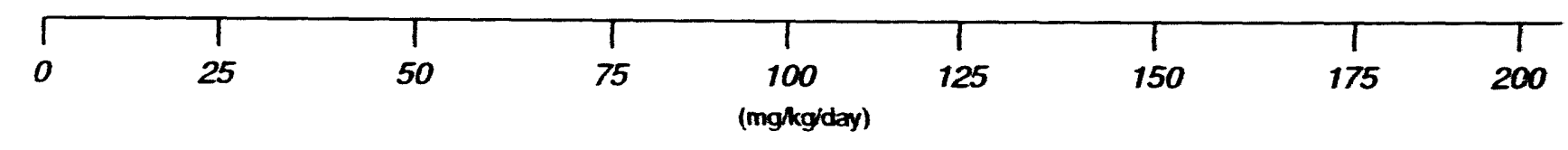

$\longleftarrow$

NO OBSERVED EFFECTS

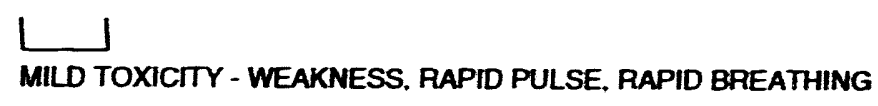

FGURE 5.1 


\section{Ilssue accumulation and clearance}

Because of its strong similarity to calcium, 99 percent of the body burden of strontium is found in bone. The average adult body burden (the amount found in normal, healthy adults) of strontium is estimated to be $320 \mathrm{mg}$ (Snyder et al., 1975). Absorbed strontium is cleared from the body primarily through urine and feces. In humans, 12 to 13 percent of an intravenous dose is eliminated in the feces. Urinary excretion accounts for nearly 60 percent of an intravenous dose and 4 to 18 percent of an ural dose (EPA, 1990). Strontium is filtered by the kidneys at a rate 3.5 times greater than calcium, and calcium is reabsorbed more efficiently than strontium, resulting in a more rapid clearance of strontium.

\section{Environmental sources of strontium}

Normal dietary intake of strontium in adult humans ranges from 0.013 to 0.021 $\mathrm{mg} / \mathrm{kg} / \mathrm{day}$. Stable strontium has been reported in drinking water supplies in Wisconsin and Dhio at concentrations ranging from 0.02 to $34.5 \mathrm{mg} / \mathrm{L}$ (Curzon, 1985). Strontium has been used medicinally since 1884, although its medicinal use has steadily declined.

\section{Texicity of strontium}

No data are available on the acute toxicity of stable strontium in humans. In laboratory studies, the range of lethal doses for orally administered strontium varied across species from a lethal dose of $1826 \mathrm{mg} / \mathrm{kg}$ for 50 percent of experimental mice $\left(L D_{60}\right)$ to an $L D_{60}$ of $7500 \mathrm{mg} / \mathrm{kg}$ in rabbits (EPA, 1990). Death resulted from respiratory failure. Intravenous administration decreased the toxic dose by as much as an order of magnitude $(148 \mathrm{mg} / \mathrm{kg}$ in mice).

No good data are available for estimating toxic effects related to long-term intake of excess stable strontium. Strontium was administered in the treatment of osteoporosis at a dose of $24 \mathrm{mg} / \mathrm{kg} /$ day for as long as $3 \mathrm{yr}$ (EPA, 1993). Although no side effects were observed, the resultant bone loss renders questionable the extrapolation of these data to a healthy population.

In rat studies, the toxicity of strontium is related to its displacement of calcium in bone; this toxicity differs with the developmental stage of the animals. The lowest intake level that produced toxicity in young rats was $380 \mathrm{mg} / \mathrm{kg} /$ day of strontium carbonate. This dose inhibited calcification of the epiphyseal plate after 3 weeks of exposure. In adult rats, this dose had no effect, but a much larger epiphyseal plate was observed following intake of 750 or $1500 \mathrm{mg} / \mathrm{kg} / \mathrm{day}$ in the adult animals (Storey, 1961). Intake of $190 \mathrm{mg} / \mathrm{kg}$ /day resulted in no observed toxicity in the young rats. In weanling rats, drinking $633 \mathrm{mg} / \mathrm{kg} / \mathrm{day}$ of strontium chloride in water resulted in slower mineralization of the bone, slower calcification, and defective long bone growth (Marie et al., 1985). No toxicity was observed in the weanling animals at $525 \cdot \mathrm{mg} / \mathrm{kg} /$ day intake of strontium chloride. These health effects are summarized in Figure 5.2 as a function of dose. 
PORTION OF SCALE BLOWN UP IN FIGURE 6.3

\begin{tabular}{|c|c|c|c|c|c|c|c}
\hline & 1 & 1 & 1 & 1 & 1 & 1 & 1 \\
0 & 50 & 100 & 150 & $\begin{array}{c}200 \\
\text { (mg/kg/day) }\end{array}$ & 250 & 300 & 350
\end{tabular}

| DIETARY INTAKE LEVELS

- oral REFERENCE dOSE

$$
\bigsqcup_{\text {NO OBSERVED SIDE EFFECTS IN TREATED HUMANS }}
$$$$
\text { NO OBSERVED EFFECTS IN YOUNG RATS }
$$ 


\subsubsection{Sulfate}

\section{Absorption}

Sulfate absorption from the gastrointestinal tract is similar between humans and other animals. Generally, greater than 90 percent absorption is reported for doses of sulfate below $150 \mathrm{mg} / \mathrm{kg}$, decreasing to 50 to 75 percent as the dose increases into the grams per kilogram range.

\section{Tissue accumulation and retention}

Ingestion of high levels of sulfate results in transient increases in both blood and urine concentrations. For sulfate doses of approximately $75 \mathrm{mg} / \mathrm{kg}$, approximately 50 percent of the dose is excreted over $72 \mathrm{hr}$. The urinary excretion mechanism is transport-limited and can therefore become saturated at high doses of sulfate. Excess sulfate is also excreted in feces in its inorganic form. To date, no available data indicate sulfate is accumulated, even with chronic ingestion of above-normal levels. However, extremely high chronic doses do not appear to have been examined in humans.

Sulfate is used in the biosynthesis of collagen, cartilage, and dentin and in the formation of sulfate esters of both endogenous compounds (such as lipids and steroids) and exogenous compounds (such as phenols). Sulfation is important in detoxication pathways because it increases the solubility of these compounds, which enhances their excretion in the urine. Exposure to high concentrations of compounds that are conjugated with sulfate and excreted can produce a transient decrease in sulfate concentrations in plasma.

\section{Environmental sources of sulfate}

Drinking water in the western United States in 1978 showed a range of sulfate concentrations from 0 to $820 \mathrm{mg} / \mathrm{L}$, with a mean sulfate concentration of $99 \mathrm{mg} / \mathrm{L}$. The EPA estimates a normal sulfate intake range of 0.00023 to $0.0064 \mathrm{mg} / \mathrm{kg} /$ day from air and up to $2.9 \mathrm{mg} / \mathrm{kg} /$ day from drinking water, in the concentration range found in the western United States (EPA, 1992a). No estimates are available on sulfate intake from food sources.

\section{Toxicity of sulfate}

As with nitrate toxicity, the acute and chronic effects of sulfate toxicity differ more in severity than in symptoms or mechanisms. Therefore, this discussion will combine acute and chronic toxicity. As mentioned above, no available data indicate bioaccumulation of sulfate with chronic exposure. Sulfate salts of magnesium and sodium are used medicinally as cathartics. The presence of high concentrations of unabsorbed sulfate salts in the gut can pull large amounts of water into the gut, greatly increasing the normal volume of feces. 
Toxicity in humans primarily manifests in diarrhea; it is produced by the same mechanism as the cathartic therapeutic effects. The severity of the diarrhea is dose-dependent. Chronic ingestion of sulfate can result in persistent diarrhea, leading to ionic imbalances and dehydration similar to that seen with extremely high, acute doses. When drinking water is contaminated with sulfate, the taste of the water may make it unpalatable and reduce consumption. This lower water intake could compound the dehydration effects of the diarrhea. Extreme dehydration can lead to death. As with nitrate toxicity, infants may be the most susceptible population for sulfate-induced diarrhea. These health effects are summarized in Figure 5.3 as a function of dose.

In cattle, high sulfate intake has resulted in sulfhemoglobinemia, a condition similar to the methemoglobinemia induced by nitrate ingestion. No cases of sulfhemoglobinemia have been reported following ingestion of sulfate by humans, although the condition does occur in humans following inhalation of hydrogen sulfide.

As with nitrate, data on sulfate toxicity are based primarily on epidemiologic studies of human adults and infants who report to hospitals with symptoms of sulfate exposure. In most cases, exposure doses were back-calculated from sampling their drinking water. Therefore, these data do not represent well-controlled studies with readily defined dosage ranges.

\subsubsection{Uranium}

The naturally occurring uranium present at UMTRA Project sites consists of three radioactive isotopes: uranium-234, uranium-235, and uranium-238. More than 99 percent of natural uranium occurs in the form of uranium-238 (Cothern and Lappenbusch, 1983). Uranium-238 undergoes radioactive decay by emitting alpha particles to form uranium-234, thorium-230, radium-226, radon-222, polonium-210, and other radioisotopes with shorter half-lives. The radioactive decay chain of uranium-238 and uranium-234 is summarized in Figure 5.4. As all uranium isotopes in nature are radioactive, the hazards of a high uranium intake are from both its chemical toxicity and its potential radiological damage. This section focuses on the chemical toxicity of natural uranium. Carcinogenic potential associated with exposure to radioactive isotopes of natural uranium is presented in Section 5.3.

\section{Absorption}

Absorption of uranium in the gastrointestinal tract depends on the solubility of the uranium compounds. The hexavalent uranium compounds, especially the uranyl salts, are water soluble, while tetravalent compounds generally are not (Weigel, 1983). Even with soluble compounds, only a small fraction is absorbed. Human gas:rointestinal absorption rates of 0.76 to 7.8 percent have been determined (Wrenn et al., 1985). 


\begin{tabular}{|c|c|c|c|c|c|c|c|}
\hline & T & 1 & $T$ & 1 & 1 & $T$ & $T$ \\
\hline 0 & 50 & 100 & 150 & $\begin{array}{r}200 \\
(\mathrm{mg} / \mathrm{kg} / \mathrm{d}\end{array}$ & 250 & 300 & 350 \\
\hline
\end{tabular}



FIGURE 5.3 

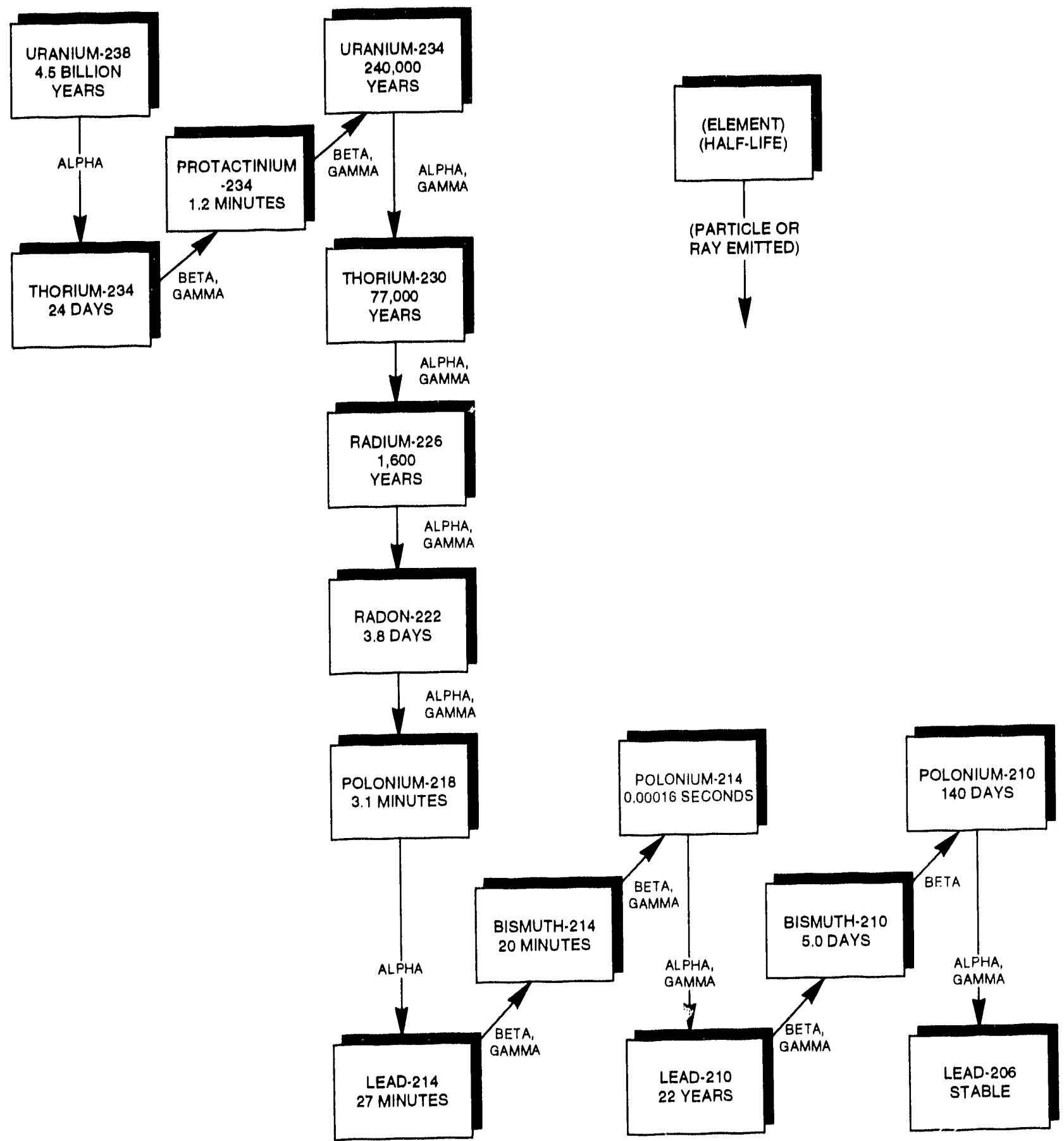

FIGURE 5.4

HALF-LIVES AND RADIATION EMISSION PATTERNS RESULTING FROM DECAY OF URANIUM-238 


\section{Tissue accumulation and clearance}

In humans exposed to background levels of uranium, the highest concentrations of uranium were found in the bone, muscle, lung, liver, and kidney (Fisenne et al., 1988). Uranium retention in the bone consists of a short retention half time of 20 days followed by a long retention half time of 5000 days for the remainder (Tracy et al., 1992).

In body fluids, uranium tends to convert into water-soluble hexavalent uranium (Berlin and Rudell, 1986). Approximately 60 percent of the uranium in plasma complexes with low-molecular-weight anions (e.g., bicarbonates, citrates), while the remaining 40 percent binds to the plasma protein transferrin (Stevens et al., 1980). Following oral exposure in humans, more than 90 percent of uranium is excreted in the feces and not absorbed in the gastrointestinal tract. Of the small percent that is absorbed (typically less than 5 percent), approximately 60 percent is excreted in the urine within $24 \mathrm{hr}$ and 98 percent is excreted within 7 days. These data are based on animal studies by Ballou et al. (1986), Leach et al. (1984), and Sullivan et al. (1986). A small portion of the absorbed uranium is retained for a longer period.

\section{Environmental sources of uranium}

Uranium is a ubiquitous element, present in the earth's crust at approximately 4 parts per million. Uranium concentrations in samples of groundwater and surface water world-wide averaged $1 \mathrm{pCi} / L$ and $3 \mathrm{pCi} / \mathrm{L}$, respectively (NCRP, 1984). It is absorbed from the soil into plant tissues to an extent that depends on the plant species and the depth of its root system (Berlin and Rudell, 1986). Plant concentrations of uranium averaged 0.075 micrograms per kilogram $(\mu \mathrm{g} / \mathrm{kg})$ fresh plant material (Tracy et al., 1983).

The main dietary source of natural uranium for the general population is food products such as bakery products, potatoes, meat, and fresh fish, which may contain uranium concentrations between 10 and $100 \mu \mathrm{g} / \mathrm{kg}$ (Prister, 1969). The total dietary uranium intake from the consumption of average foods is approximately $1 \mu \mathrm{g} /$ day. Cereals and vegetables, particularly root crops, are likely to contribute most to the daily uranium intake (Berlin and Rudell, 1986).

\section{Toxicity of uranium}

Exposure of the general public to natural uranium is unlikely to pose an immediate lethal threat to humans. No human deaths have been reported that are attributable to uranium ingestion; therefore, no lethal dose has been determined for humans. The lethal dose for animals ranges from 8 to $242 \mathrm{mg}$ uranium $/ \mathrm{kg}$, depending on both the solubility of the uranium compound (higher solubility compounds have greater toxicityl and the animal species tested. High doses of uranium cause complete kidney and respiratory failure. 
No chronic toxic effects have been reported in humans following oral exposure to uranium. Data available from populations occupationally exposed to high concentrations of uranium compounds through inhalation and data from studies on experimental animals indicate the critical organ for chronic uranium toxicity is the proximal tubule of the kidney (Friberg et al., 1986). In humans, chemical injury reveals itself by increased catalase excretion in urine and proteinuria. Dose-response data for the toxic effect of uranium on the human kidney are limited.

The lowest dose of uranyl nitrate that caused moderate renal damage was given to rabbits in diet at $2.8 \mathrm{mg} / \mathrm{kg} /$ day (Maynard and Hodge, 1949). The health effects for uranium are summarized in Figure 5.5 as a function of dose.

\subsubsection{Vanadium}

\section{Absorption}

Absorption of vanadium from the gastrointestinal tract is low. In a healthy young man, orally administered sodium metavanadate $(12.5 \mathrm{mg} / \mathrm{d}$ for 12 days) was completely recovered: The majority ( 87.6 percent) of the dose was unabsorbed in feces, and the remainder (12.4 percent) was excreted in urine (Proescher et al., 1917). Essentially the same result was obtained by Tipton et al. (1969) in a dietary balance study (50 weeks, 2 subjects). The urine to diet ratio for vanadium was approximately 0.13 ; the same value was obtained for the urine to excreta ratio.

Less than 0.1 percent of an intragastric dose was detectable in the blood of rats at 15 minutes postexposure, and less than 1 percent at $1 \mathrm{hr}$ postexposure (Roshchin, 1968). Uptake of radioactive $\mathrm{V}_{2} \mathrm{O}_{5}$ given orally to rats was 2.6 percent of the administered dose. The ICRP (1960) estimate for the absorption of soluble vanadium compounds is 2 percent. Soluble vanadium compounds that are inhaled and deposited are readily absorbed. Because vanadium is a metal of low solubility, absorption througl, the skin is probably minimal (EPA, 1977).

\section{Tissue accumulation and clearance}

Vanadium is found in all body tissues in concentrations ranging from $0.08 \mu \mathrm{g} / \mathrm{g}$ wet weight in spleen tissue to $0.14 \mu \mathrm{g} / \mathrm{g}$ in brain and heart tissue and $0.33 \mu \mathrm{g} / \mathrm{g}$ in aorta tissue (Yakawa and Suzuki-Yasumoto, 1980). Concentrations of vanadium in human blood serum are reported to be 0.016 to 0.939 nanogram $(\mathrm{ng}) / \mathrm{mL}$. In hair, concentrations of vanadium ranging from 20 to $60 \mathrm{ng} / \mathrm{gram}(\mathrm{g})$ have been reported by different authors, with higher values found in manicdepressive patients than in normal control groups (57 versus $29 \mathrm{ng} / \mathrm{g}$ ). 


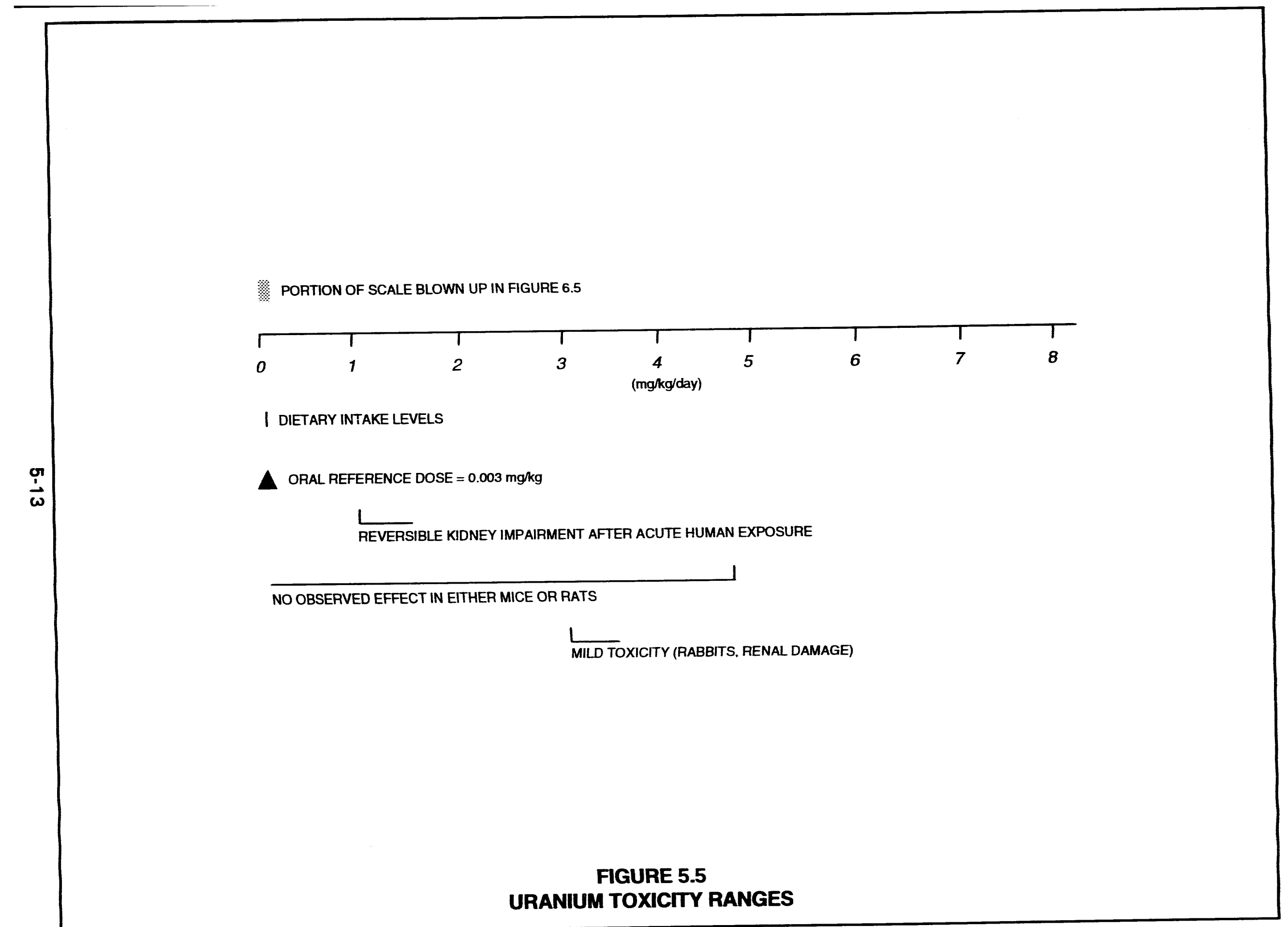


The distribution of vanadium in humans following oral exposure may be extrapolated from animal studies. In acute-duration exposures, vanadium is rapidly distributed, primarily in the bones. After intermediate-duration exposure, vanadium concentrations reaching the tissues are low, with the kidneys, bones, liver, and lungs initially showing the highest levels.

Vanadium is an element and is not metabolized. However, in the body, there is an interconversion of two oxidation states of vanadium: vanadyl and vanadate. Vanadium can reversibly bind to the protein transferrin in the blood and then be taken up into erythrocytes. There is a slower uptake of vanadyl into erythrocytes compared to the vanadate form, possibly due to the time required for the vanadyl form to be oxidized to vanadate. Initially, vanadyl leaves the blood more rapidly than vanadate, possibly because of the slower vanadyl uptake into cells (Harris et al., 1984). Five hours after adrninistration, blood clearance is essentially identical for the two forms.

Because vanadium is poorly absorbed in the gastrointestinal tract, a large percentage of vanadium in rats is excreted unabsorbed in the feces following oral exposure. In rats, the principal route of excretion of the small absorbed portion of vanadium is through the kidneys. The mean urinary output per $24 \mathrm{hr}$ is reported to be $10 \mu \mathrm{g}$.

\section{Environmental sources of vanadium}

Elemental vanadium does not occur in nature but its compounds exist in more than 50 different mineral ores and in association with fossil fuels. The single largest release of vanadium to the atmosphere occurs through the combustion of fossil fuels, particularly residual fuel oils. The largest amount of vanadium released to soil and water occurs through the natural weathering of geological formations (Byerrum et al., 1974; Van Zinderen Bakker and Jaworski, 1980).

Food constitutes the major source of exposure to vanadium for the general population (Lagerkvist et al., 1986). For the general population as a whole, dietary intake is estimated to be 6 to $18 \mu \mathrm{g}$ /day (Pennington and Jones, 1987), although other estimates from older studies utilizing different and possibly less sensitive analytical methods have been as high as $2 \mathrm{mg} /$ day (Schroeder et al., 1963).

Drinking water is not considered an important source of vanadium exposure for the general population. Water samples taken from across the United States show 92 percent with values below $10 \mu \mathrm{g} / \mathrm{L}$. Typical values appear to be around $1 \mu \mathrm{g} / \mathrm{L}$ (Lagerkvist et al., 1986). The estimated daily intake of vanadium by the inhalation route is $1 \mu \mathrm{g}$ (Byrne and Kosta, 1978).

Although vanadium is considered an essential element for chickens and rats, there is no certainty about human dietary requirements. For animals, the daily requirement is about 10 to $25 \mu \mathrm{g} /$ day (Pennington and Jones, 1987). 


\section{Texicity of vanadlum}

The major adverse health effect to humans from vanadium is seen in workers exposed to large amounts of vanadium pentoxide dusts. The probable oral lethal dose of vanadium pentoxide for humans is between 5 and $50 \mathrm{mg} / \mathrm{kg}$ (Gosselin et al., 1976).

Systemic effects of vanadium exposure have been observed in the liver, kidneys, nervous and cardiovascular systems, and blood-forming organs. Metabolic effects include interference with the biosynthesis of cystine and cholesterol, depression and stimulation of phospholipid synthesis and, at higher concentrations, inhibition of serotonin oxidation. Other effects of vanadium on mammalian metabolism include depression of phospholipid synthesis (Snyder and Cornatzer, 1958), reduction of coenzyme $Q$ levels in mitochondria (Alyar and Sreenivasan, 1961l, and stimulation of monoamine oxidase, which oxidizes serotonin (Perry et al., 1955).

Vanadium salts were given to patients in several studies to reduce cholesterol (Curran et al., 1959; Somerville and Davies, 1962; Dimond et al., 1963;

Schroeder et al., 1963). The doses of vanadium in these studies varied from $7 \mathrm{mg} /$ day to $30 \mathrm{mg} / \mathrm{day}$. Transient decreases in serum cholesterol levels were observed in some patients, as were loosened stool and cramps. Green tongue, a hallmark of vanadium exposure, was observed in all patients.

A relationship between the concentration of vanadium in drinking water and the incidence of dental caries in children is reported by Tank and Storvick (1960). Dental caries incidence in children aged 7 to $11 \mathrm{yr}$ was reduced three times (compared to controls) by applying ammonium vanadate in glycerol to the teeth (Belehova, 1969). This relationship was not found in other studies (Hadjimarkos, 1966; 1968).

It has been suggested that raised tissue levels of vanadium are important in the etiology of manic-depressive illness. Improvement after treatment with ascorbic acid or reduced vanadium intake was seen both in manic and depressed patients.

The toxicity of vanadium is summarized in Figure 5.6.

\subsection{CONTAMINANT INTERACTIONS}

A primary concern about Monument Valley groundwater is the potential for nitrate-sulfate interactions. As discussed above, no clear data are available to assess this interaction, but epidemiological evidence suggests that in infants, gastrointestinal upset such as that caused by sulfate could increase sensitivity to methemoglobinemia produced by nitrates. However, it is also possible that sulfate-induced diarrhea could decrease the nitrate-reducing bacteria in the intestine, thereby decreasing nitrate toxicity. 




$\triangle$ ORAL REFERENCE DOSE (HEAST)

TRANSIENT CHOLESTEROL DROP. CRAMPS. GREEN TONGUE (100-400 ug/kg/day)

ESTIMATED LETHAL DOSE (5000 - 50000 ug/kg/day)

FIGURE 5.6

HEALTH EFFECTS OF VANADIUM 
Interactions between nitiate, sulfate, and hemoglobin also occur. However, no studies have been found that address the potential interactions of combined exposure to high nitrate and sulfate concentrations. Nitrate has been used in the treatment of hydrogen sulfide poisoning. The hydrosulfide anion binds to methemoglobin to form sulfmethemoglobin, effectively removing circulating hydrosulfide. Additional data are needed to assess the likelihood of hydrosulfide formation with oral sulfate exposure or the subsequent formation or stability of sulfmethemoglobin.

Strontium toxicity is strongly influenced by calcium intake. Toxicity is enhanced in low-calcium conditions and decreased in the presence of high calcium. Although eliminated as a contaminant of concern at Monument Valley because concentrations fell within dietary ranges, calcium is elevated in groundwater and therefore may act to decrease strontium toxicity.

\subsection{CONTAMINANT RISK FACTORS}

The EPA Office of Research and Development has calculated acceptable intake values, or reference doses (RfD), for long-term (chronic) exposure to noncarcinogens. These values are estimates of route-specific exposure levels that would not be expected to cause adverse effects when exposure occurs for a significant portion of the lifetime. The RfDs include safety factors to account for uncertainties associated with limitations of the toxicological data base, including extrapolating animal studies to humans and accounting for response variability from sensitive individuals. These values are updated quarterly and published in the Health Effects Assessment Summary Tables (HEAST) (EPA, 1992b). Following more extensive review, they also are provided through the EPA's Integrated Risk Information System (IRIS) data base. The most recent oral RfDs for the noncarcinogenic contaminants of concern are summarized in Table 5.1.

The EPA currently classifies all radionuclides as Group $A$, or known human carcinogens, based on their property of emitting ionizing radiation and on the evidence provided by epidemiological studies of radiation-induced cancer in humans. Risk factors are published in HEAST and IRIS for correlating intake of carcinogens over a lifetime with the increased excess cancer risk from that exposure. The most recent cancer slope factors for uranium-234 and -238 are given in Table 5.2 . 


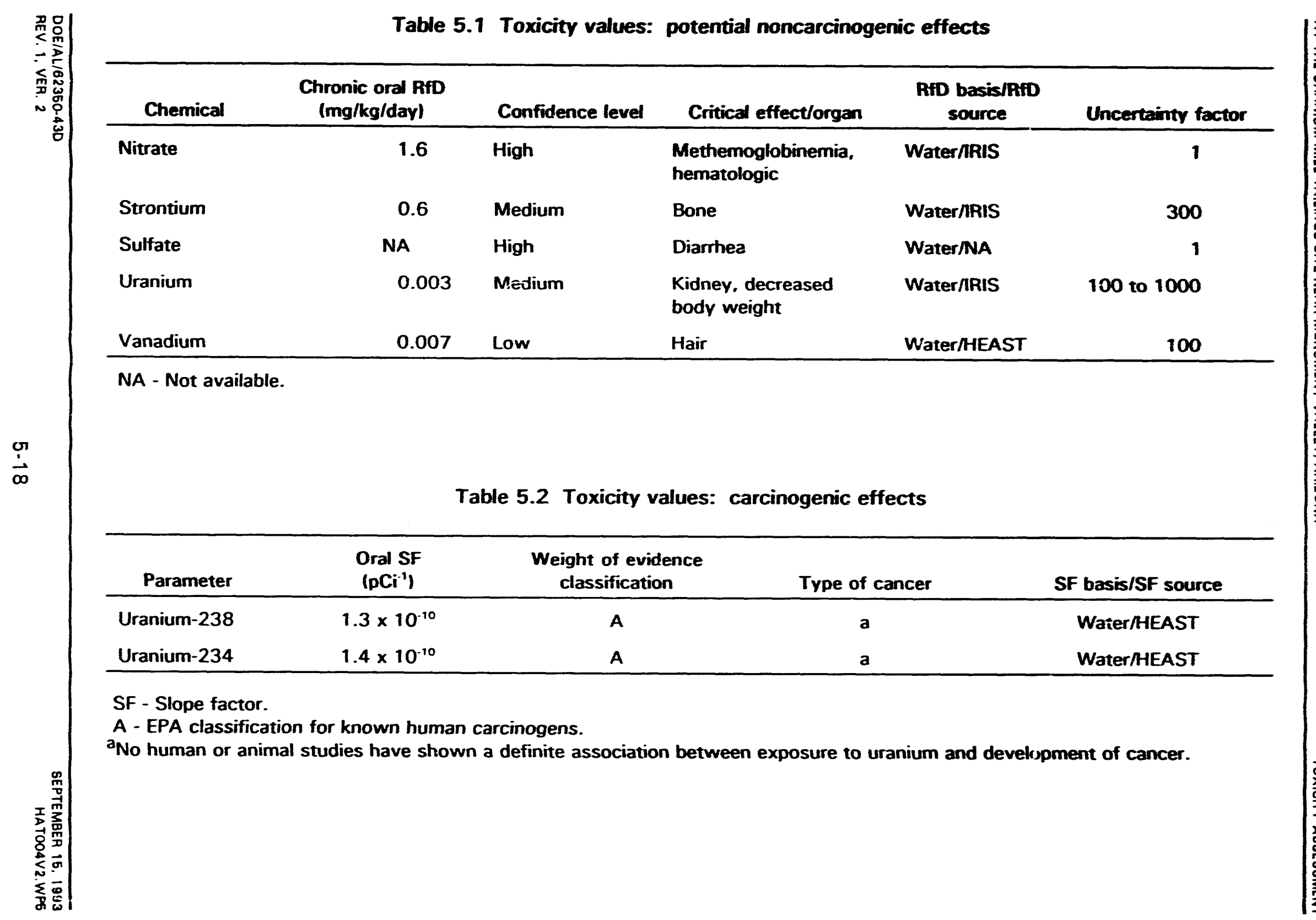




\subsection{RISK EVALUATION}

To evaluate human health risks to an individual or population, the results of the exposure assessment are combined with the results of the toxicity assessment. As discussed in Section 5.0, potential adverse health effects are entirely a function of how much nf tho contaminant an individual takes into his or her body. Indeed, at lower levels many of the contaminants assnriated with the mill tailings are beneficial to health, since they are essential nutrients. At higher levels, these same elements can cause adverse health effects or, at very high levels, death. In this section, the expected intake, if groundwater within the plume were used as drinking water, is correlated to potential health effects from these levels of exposure.

\subsection{POTENTIAL NONCARCINOGENIC HEALTH EFFECTS}

The results from the exposure assessment showing either the highest intake-tobody-weight ratios (or highest doses) or the toxicologically most sensitive group are used to evaluate potential health ef ects for noncarcinogens. For strontium, sulfate, uranium, and vanadium, the highest intake-per-body-weight groups are children 1 to $10 \mathrm{yr}$ old. For nitrate, infant exposures are used to evaluate health risks, because this is the toxicologically sensitive population.

The most significant potential health risk associated with drinking contaminated groundwater at the Monument Valley mill site is from nitrate. As can be seen in Figure 6.1, if groundwater were used for drinking water, more than 50 percent of the expected exposures would be above the potentially lethal level for infants. Some degree of methemoglobinemia would be expected with any infant consumption of groundwater, with more than 70 percent of the predicted exposure range falling above the severe toxicity level.

The levels of nitrate associated with lethal cases of methemoglobinemia vary ronsiderably. A major cofactor in nitrate toxicity may be the presence of bacterial contamination of the groundwater, thus increasing reduction to nitrite in the gut. This factor has not been evaluated in Monument Valley groundwater. A second significant factor appears to be that infants prone to gastrointestinal distress seem to be more sensitive to the toxic effects of nitrates. For this reason, it is possible that the gastrointestinal effects associated with sulfate exposures could increase the toxicity of nitrate. However, it is also possible that sulfate-induced diarrhea could decrease the intestinal content of nitrate-reducing bacteria, making nitrate less toxic. Likewise, these high sulfate concentrations may cause the water to be unpalatable to infants, thus reducing their exposure.

Figure 6.2 shows that much of the exposure distribution for sulfate is above the range where mild diarrhea would be expected, and nearly 50 percent of the exposures are above the range of severe diarrhea. Because the predicted nitrate and sulfate toxicity from drinking water is so severe, and because this is the only exposure pathway for infants, the additive contributicn from other sources 


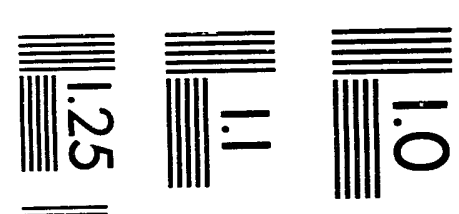

$$
\begin{aligned}
& \sqrt{\bar{\alpha}} \\
& \text { Eme }
\end{aligned}
$$



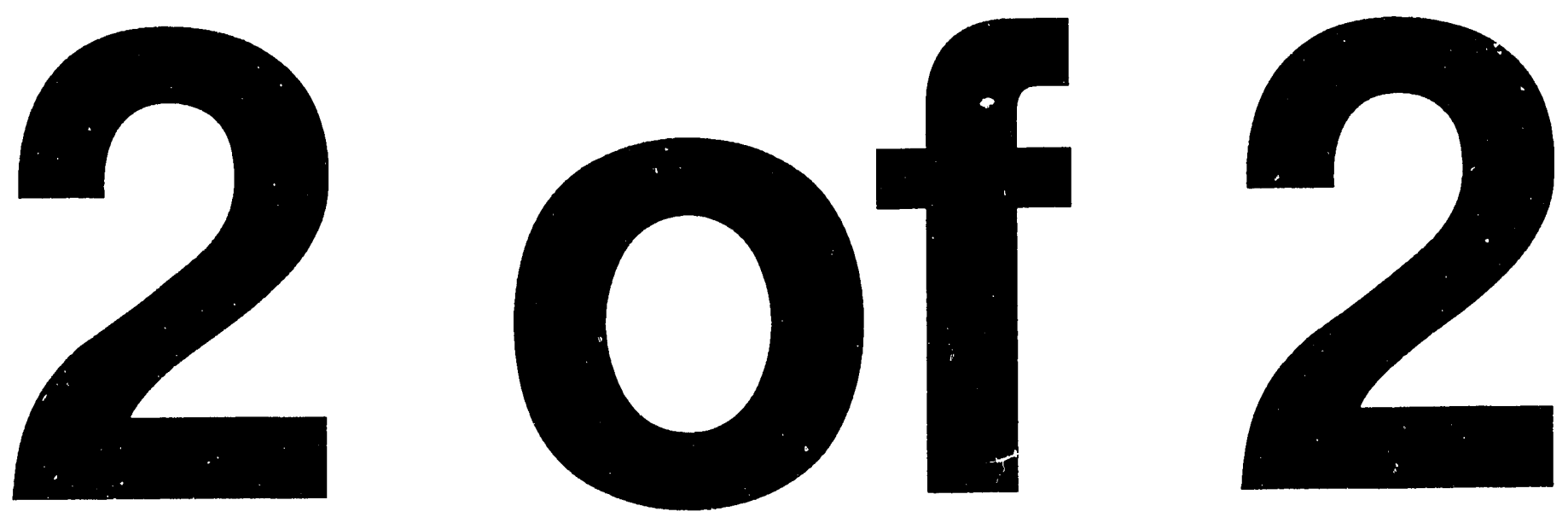


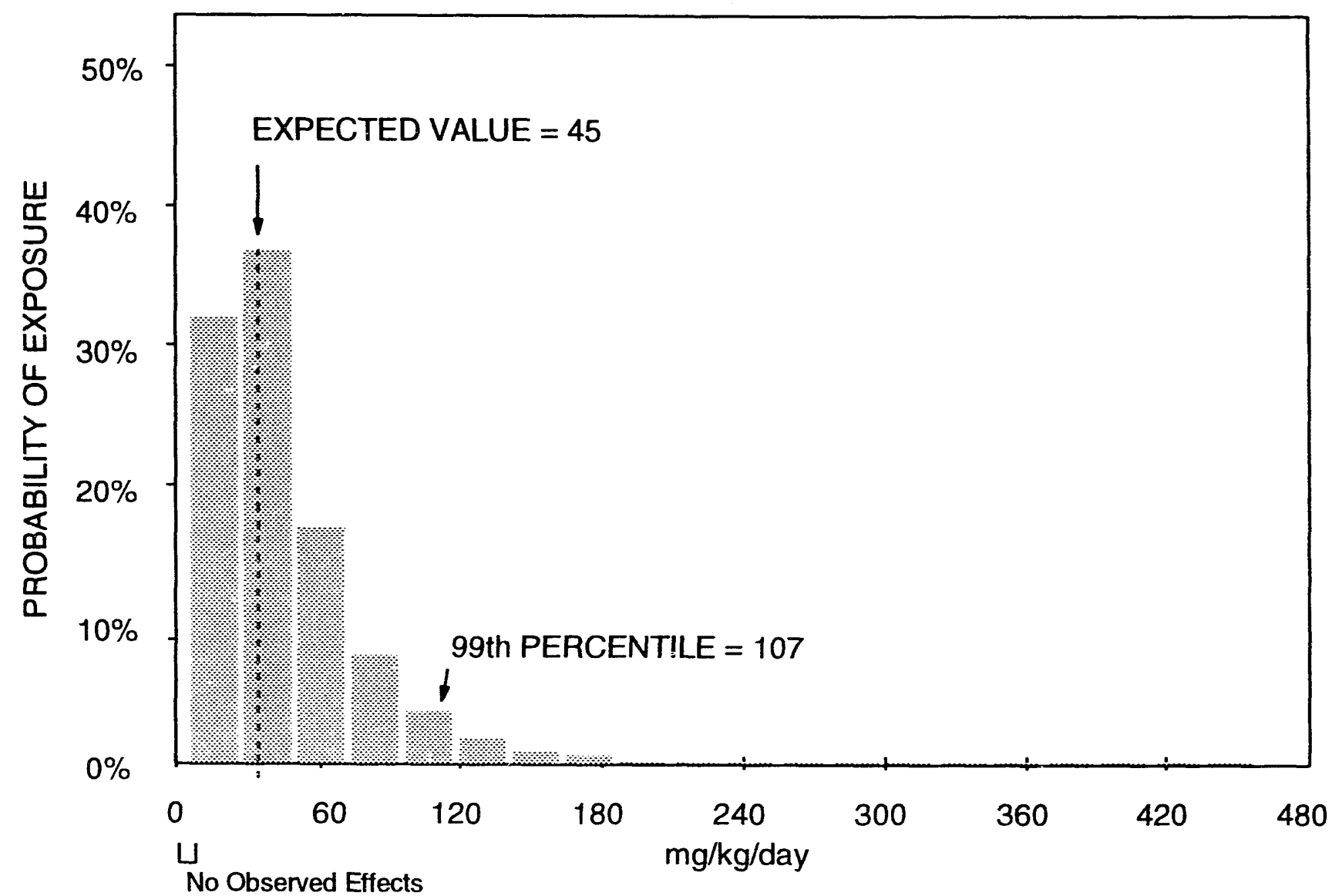

No Observed Effects

$\sqcup$

Mild Toxicity - Weakness, Rapid Pulse, Rapid Breathing

L_ـ

Severe Toxicity -- Methemoglobinemia Increases, Cyanosis, Coma

Potentially Lethal Methemoglobinemia

NOTE: SEVERE TOXIC EFFECTS AND POTENTIALLY LETHAL METHEMOGLOBINEMIA WOULD RESULT FROM THE MAJORITY OF PREDICTED INFANT EXPOSURES.

FIGURE 6.1

HEALTH EFFECTS OF PREDICTED NITRATE EXPOSURE RANGES FOR INFANTS

MONUMENT VALLEY, ARIZONA, SITE 


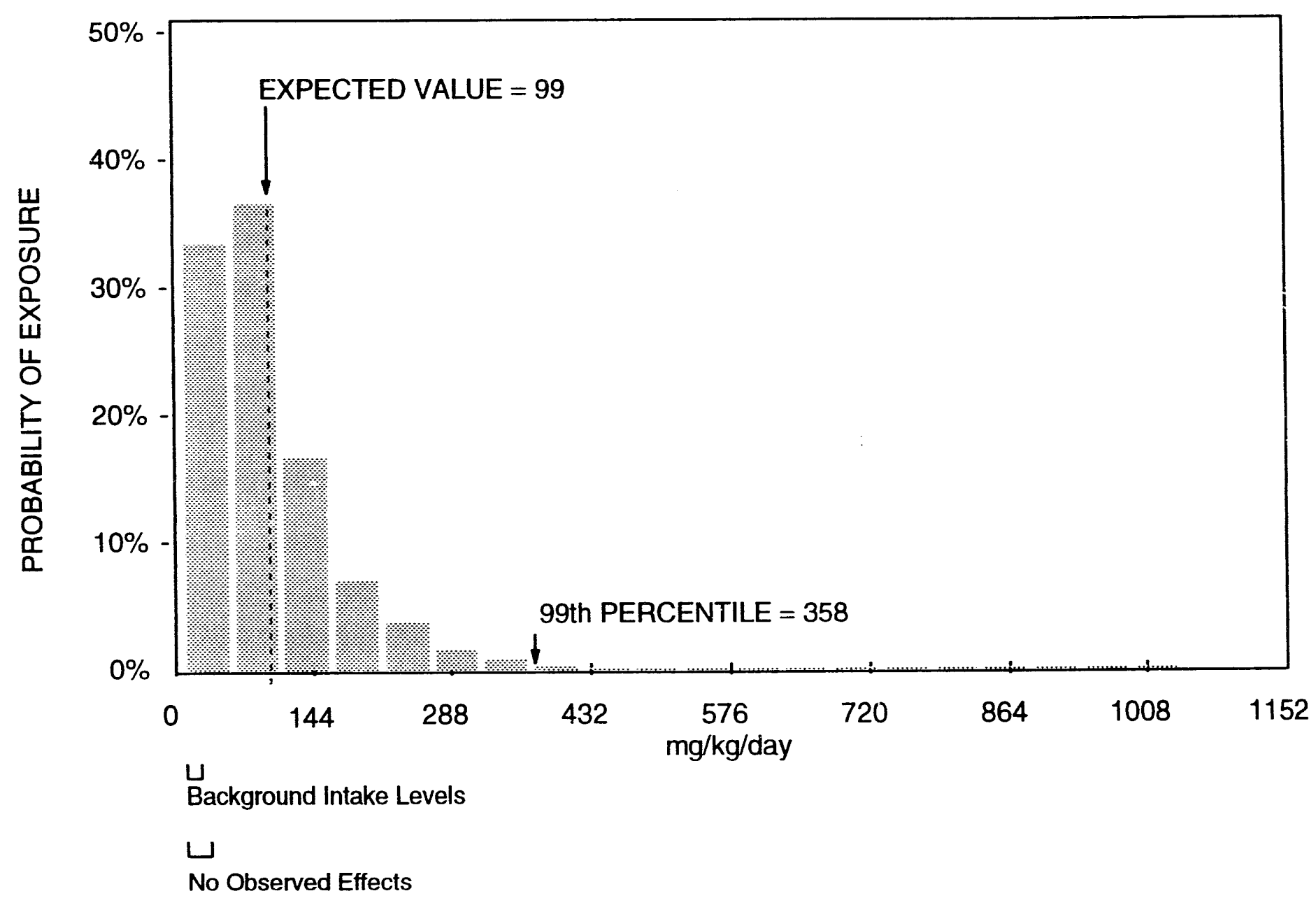

Mild Toxicity Ranging from Laxative Effect to Diarrhea in Infants

Severe Toxicity -- Persistent Infant Diarrhea Leading to Dehydration

NOTE: LAXATIVE EFFECTS MANIFESTED AS DIARRHEA IN INFANTS COULD OCCUR EVEN WITHIN' THE LOWER RANGE OF PREDICTED EXPOSURES WITH SEVERE DEHYDRATION IN

FIGURE 6.2 INFANTS OCCURING AT HIGHER PREDICTED EXPOSURES.

HEALTH EFFECTS OF PREDICTED SULFATE EXPOSURE RANGES FOR CHILDREN MONUMENT VALLEY, ARIZONA, SITE 
would not alter the interpretation of health risks. Therefore, it will not be evaluated at this time.

It is also important to note that the exposure distribution for infants is based on tap water intake rates across a population that includes breast-fed and canned-formula-fed infants. Those infants consuming powdered formula reconstituted with well water would be in the upper percentiles of this exposure distribution and could be at high risk of severe diarrhea and methemoglobinemia. Further, these effects would be expected after very short-term exposures.

For the remaining contaminants of concern at Monument Valley, very few if any adverse effects are anticipated from chronic groundwater ingestion. For strontium (Figure 6.3) and vanadium (Figure 6.4), more than 99 percent of the exposure distribution falls below the EPA-derived oral $R f D$. The remaining portion of these distributions is well below any toxic effects observed in humans. For uranium (Figure 6.5), more than 95 percent of the predicted exposure range is below the EPA oral RfD. All the distribution is well below any toxic effects observed in humans. Because of the very low concentrations and therefore low predicted toxicity for these metals from drinking water, the minor exposure pathways presented in Section 4.0 would not be expected to contribute significantly to toxicity at this site. For example, in the unconsolidated aquifer, screening calculations indicated that ingestion of produce contributed 15 percent of the strontium exposure obtained from water ingestion. Because the toxicity of strontium even from water ingestion was so low, the additional contribution from produce ingestion would not shift the distribution into a range where adverse health effects would be expected. Therefore, no further evaluation of this secondary pathway was considered.

Although some of these constituents are elevated in the deeper aquifers, no risk simulation has been done based on data from these aquifers. The concentrations of these constituents in the Shinarump were 2 percent of the unconsolidated aquifer value for nitrate, 10 percent for sulfate, and 20 percent for strontium. Therefore, the health effects expected from ingestion of the Shinarump concentrations of these constituents would be minimal relative to the unconsolidated aquifer.

Although uranium concentrations from wells 614 in the Shinarump and 657 in the DeChelly exceeded concentrations observed in the unconsolidated aquifer, risk calculations have not been carried out based on these wells. Because the source of these elevated uranium levels is at present undetermined, further evaluation of this issue will be considered in the groundwater phase of the UMTRA Project.

\subsection{POTENTIAL CARCINOGENIC HEALTH EFFECTS}

All uranium isotopes are radioactive and, as such, are considered potential carcinogens. The exposure distribution for uranium intake from the most contaminated well in the unconsolidated aquifer and the potential lifetime 


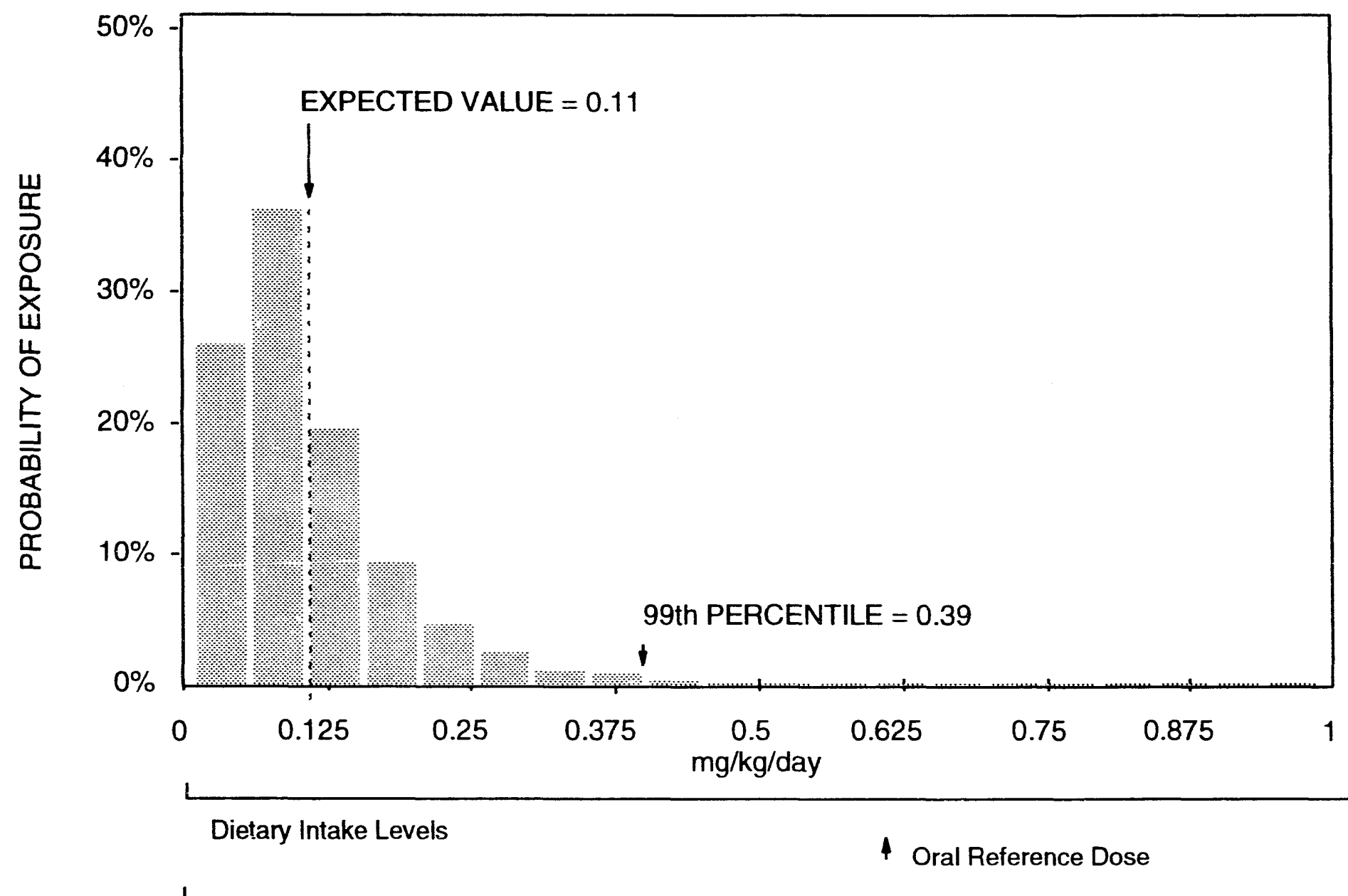

No Observed Side Effects in Treated Humans

No Observed Effects in Young Rats

NOTE: NO OBSERVED ADVERSE HEALTH EFFECTS HAVE BEEN ASSOCIATED WITH THE PREDICTED RANGE OF EXPOSURES.

FIGURE 6.3

HEALTH EFFECTS OF PREDICTED STRONTIUM EXPOSURE RANGES FOR CHILDREN MONUMENT VALLEY, ARIZONA, SITE 


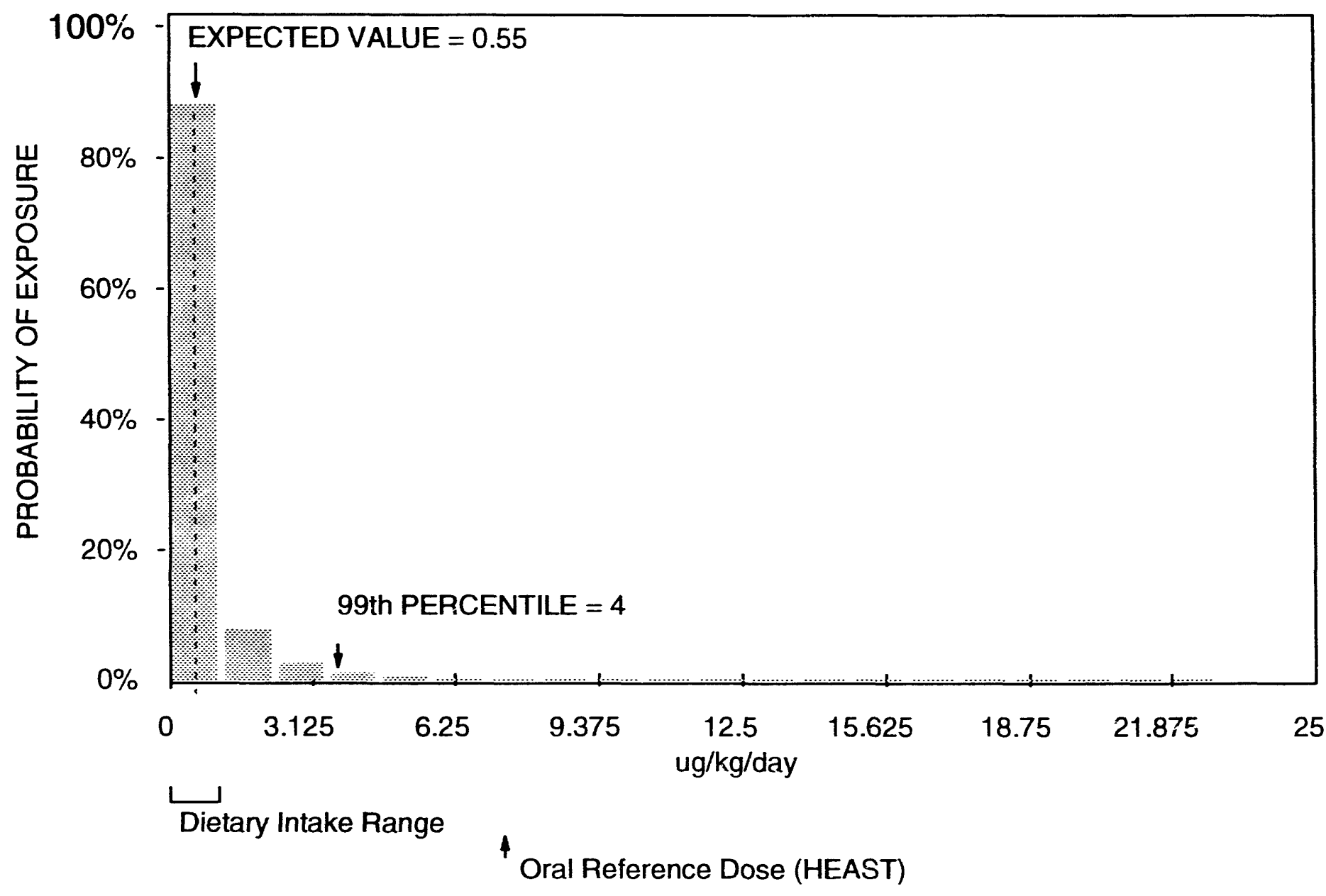

Transient cholesterol drop, cramps, green tongue $(100-400 \mathrm{ug} / \mathrm{kg} / \mathrm{day})$

Estimated lethal dose (5000 - $50000 \mathrm{ug} / \mathrm{kg} /$ day $)$

NOTE: NO OBSERVED ADVERSE HEALTH EFFECTS HAVE BEEN ASSOCIATED WITH THE PREDICTED RANGE OF EXPOSURES.

FIGURE 6.4

HEALTH EFFECTS OF PREDICTED VANADIUM EXPOSURE RANGES FOR CHILDREN MONUMENT VALLEY, ARIZONA, SITE 


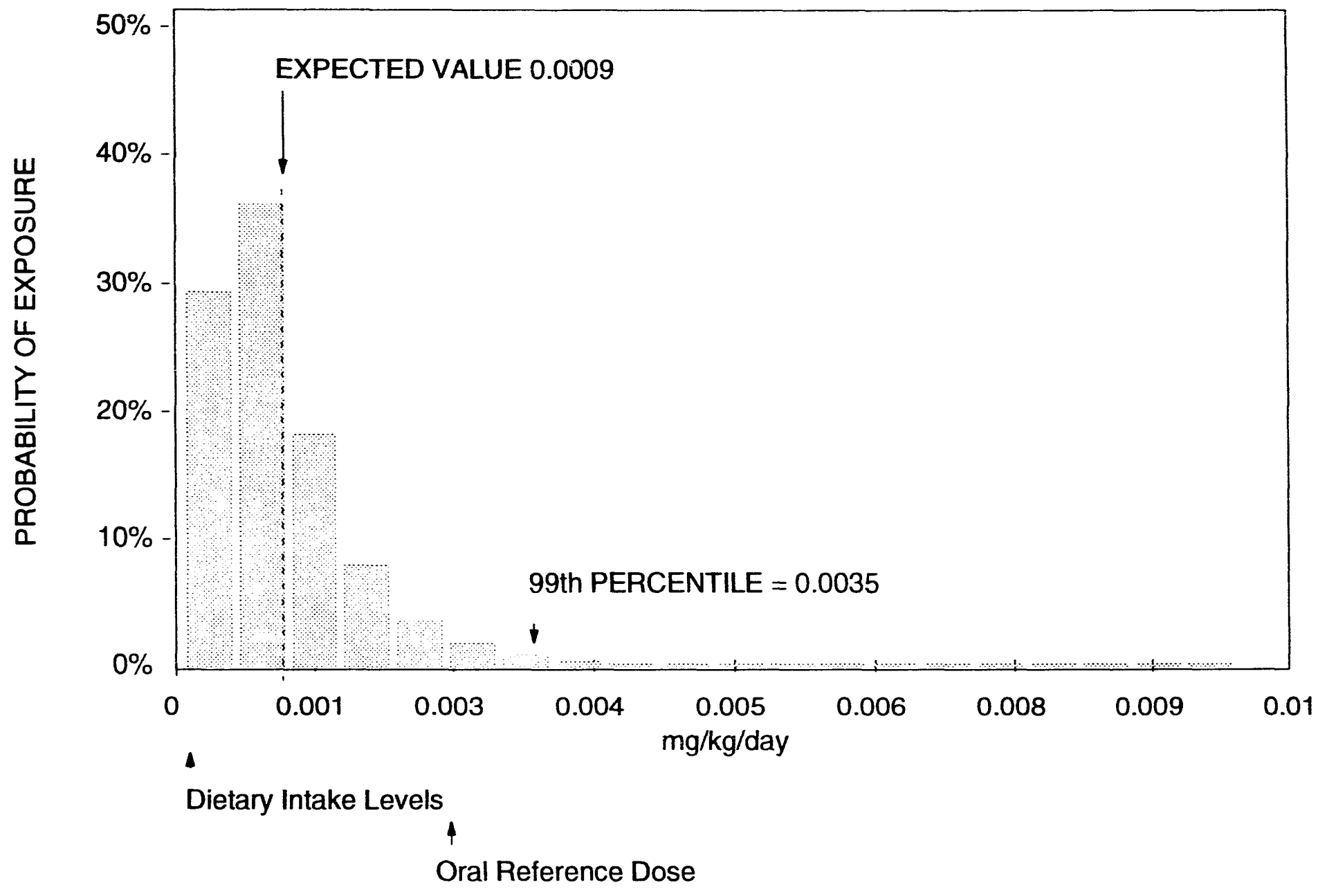

Reversible Kidney Impairment -- Humans (1 mg/kg/day)

NOTE: THE LOWEST EXPOSURE LEVEL RESULTING IN KIDNEY IMPAIRMENT IS 2 ORDERS OF MAGNITUDE GREATER THAN THE HIGHEST PREDICTED EXPOSURES FROM GROUNDWATER INGESTION.

FIGURE 6.5

HEALTH EFFECTS OF PREDICTED URANIUM EXPOSURE RANGES FOR CHILDREN MONUMENT VALLEY, ARIZONA, SITE 
carcinogenic risk associated with these drinking water exposures are shown in Figure 6.6. These estimates are based on the cancer slope factor developed by the EPA; however, natural uranium has not been demonstrated to cause cancer in humans or animals following ingestion exposures. Approximately 80 percent of the exposure distribution for groundwater ingestion of uranium falls below the National Contingency Plan guidance for maximum increased lifetime cancer risk of $1 \times 10^{-4}$. The expected exposure value results in an excess lifetime cancer risk of $7 \times 10^{0.5}$. The distribution presented here is thought to be conservative because it is based on cumulative 70-yr exposure durations. As discussed previously, this exposure duration is probably appropriate, but groundwater uranium concentrations resulting from processing at this site would be expected to decline after the tailings are removed. Therefore, this distribution would overestimate risk.

Uranium is the only radionuclide measured above background in the plume. No other progeny have been detected above background levels. Therefore, no evaluation of uranium decay products was needed. 


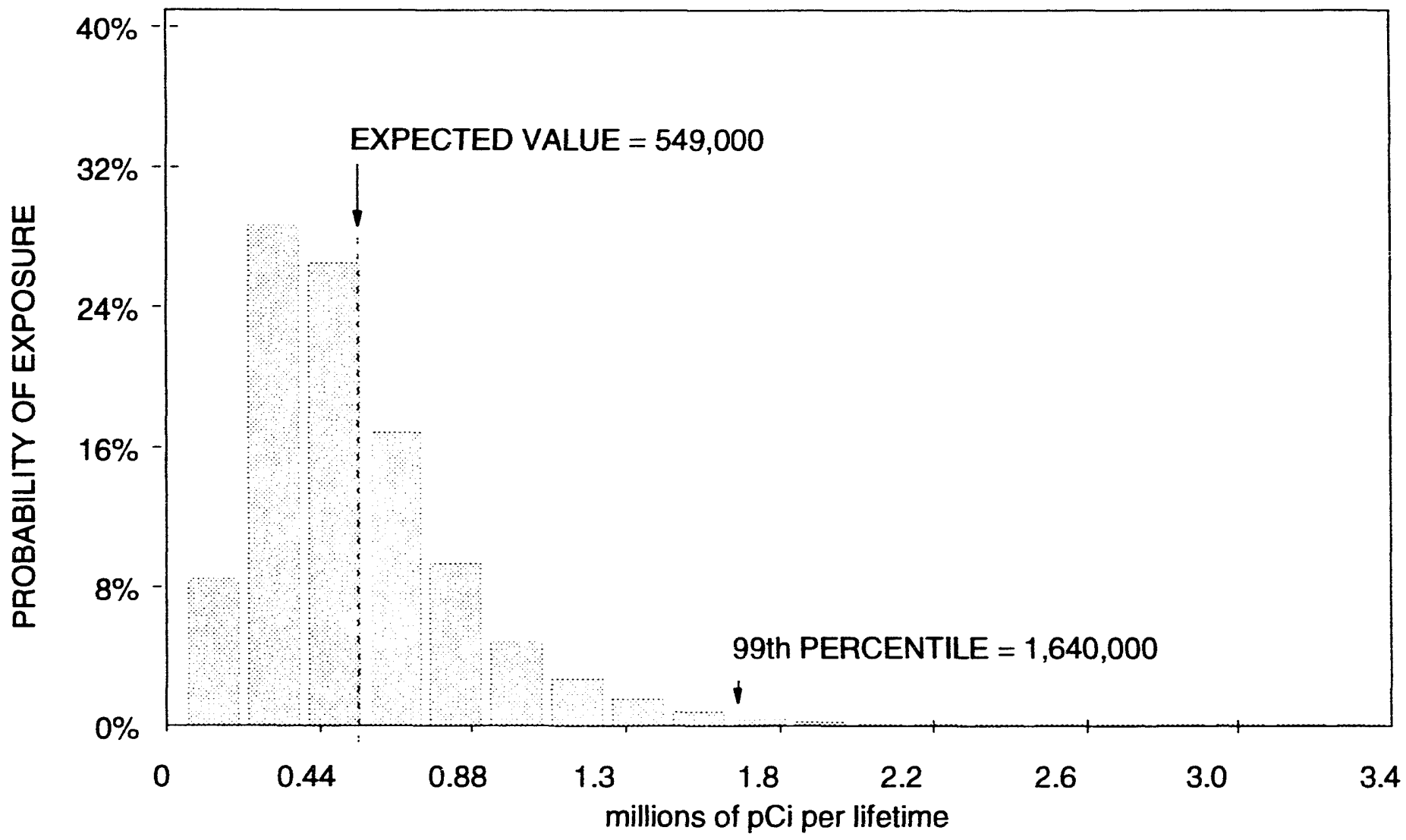

$4 \times 10^{-5}$

$1 \times 10^{-5}$

$1 \times 10^{-4}$

NOTE: THE AVERAGE PREDICTED EXPOSURE IS RELATED TO AN INCREASED CANCER RATE OF $0.007 \%$.

FIGURE 6.6

INCREASED LIFETIME CANCER RISK ASSOCIATED WITH PREDICTED RADIATION EXPOSURES RESULTING FROM INGESTION OF URANIUM IN GROUNDWATER

MONUMENT VALLEY, ARIZONA, SITE 


\subsection{LIVESTOCK AND ENVIRONMENTAL EVALLATION}

The objective of this environmental risk assessment is to determine if contaminants detected at the site could adversely affect the existing biological community at or surrounding the site. Currently, the EPA has no guidance for quantifying potential impacts to ecological receptors but has developed a qualitative approach generally used for ecological evaluation (EPA, 1989). With the qualitative approach, the EPA recommends comparing ambient environment II media concentrations with relevant criteria (including water quality) to determine if any concentrations the ecological receptors are expected to encounter exceed these criteria.

Ecological assessment can be distinguished from human health assessments in that ecological relationships influence the environment. Environmental toxicology, or ecotoxicology, combines the sciences of ecology and toxicology to study the ecological effects of environmental contaminants. Contaminants are defined as environmental constituents that occur at high enough concentrations to cause deleterious biological effects (Moriarty, 1988). Toxicology has focused largely on studying the effects of single compounds on individual organisms. In ecotoxicology, this study extends to include the effects of multiple constituents on the ecosystem.

An ecosystem is composed of both abiotic and biological components. The abiotic component is called the habitat. Biological components are organized into species, populations, and communities. A population is composed of individuals of a species that occur within a defined area, and a community is a collection of all populations (plant, animal, bacteria, and fungi) that live in a defined area and interact with one another. In practice, it is not always easy to set the boundaries for populations and communities. The community plus its habitat is an ecosystem (Moriarty, 1988).

The prediction of ecotoxicological effects from constituents is extremely complicated. Ecosystems are not static; the biological components experience constant fluctuations both in population numbers and relative composition. Abiotic factors (e.g., temperature, precipitation, nutrient availability) are also constantly changing. The stability of an ecosystem is therefore determined to a great extent by the ability to respond to normal stresses. Because normal or baseline conditions are not well understood or defined for any ecosystem, it is difficult to determine whether changes in ecological parameters (e.g., diversity, total biomass, or reproductive trends) are associated with contaminants or merely reflect normal fluctuations.

It is possible that ecotoxicological effects on individual organisms or populations may not affect the ecosystem at all. If a prey species is affected, predators may be able to shift to feeding on other species; predator loss may be compensated for by other predators or by immigration of another predator population. Recognizing when an adverse effect has occurred, or is occurring, is a challenge. Unless a mass killing occurs within a population or community, ecotoxicological effects may go unnoticed. Sublethal effects such as behavioral changes, reduced reproductive success, enzyme level changes, and effects on microorganisms can affect interdependent populations or communities (e.g., reproductive success in one species may influence another, dependent species). Identifying and 
measuring sublethal effects is often difficult. Establishing a causal relationship for a specific environmental stressor, such as a specific contaminant, is accomplished only rarely. Neither sublethal effects nor gross impacts have been reported in previous sitespecific documents, nor have they been observed by field staff at Monument Valley.

The effects of contaminants on ecological receptors at the UMTRA sites are a concern; however, because scientific understanding of ecosystem interactions is limited, it is difficult to predict if observed effects on individual populations will result in any real damage to the ecosystem. Because populations are dynamic, establishing the normal range of variability within a population is vital to ecological studies. Sublethal effects, which may be very important to overall ecosystem health, are difficult to detect, and contaminants present at low concentrations may not kill organisms directly but may diminish their ability to survive and reproduce.

\subsection{EXPOSURE CHARACTERIZATION}

This section identifies the ecological resources present at the site that are likely to be exposed to site-related contaminants and identifies the possible and probable exposure pathways. As noted in Section 4.0, exposure can occur only if there are both a source of contamination and a mechanism of transport to a receptor population or individual.

Currently, contaminated media at the site include the two piles of tailings and associated contaminated soil and groundwater. However, the tailings and contaminated soil will be stabilized in a disposal cell $17 \mathrm{mi}$ away, which is scheduled for completion by 1994. Therefore, direct-exposure pathways (such as incidental ingestion of soil, dermal contact with soil, and inhalation of air containing particulates) will not represent a future ecological concern and will not be evaluated in this baseline risk assessment. Indirect-exposure pathways (such as bioaccumulation or consumption of previously exposed organisms) are possible at the site.

Running south to north, the perennial surface water body nearest the tailings site is Cane Valley Wash, approximately $1500 \mathrm{ft}$ east of the lower tailings pile. A few areas of ponded water exist approximately $1500 \mathrm{ft}$ to $2000 \mathrm{ft}$ eastnortheast of the lower tailings pile in the Cane Valley Wash floodplain (Figure 2.12). These ponds appear to have been excavated into Cane Valley Wash. These areas of ponded water historically have been referred to as ephemeral, and the local residents refer to them as the "frog ponds." As discussed previously, the plume of impacted groundwater in the unconsolidated aquifer is traveling north-northeast by as much as $300 \mathrm{ft} / \mathrm{yr}(100 \mathrm{~m} / \mathrm{yr})$. Not enough data are available to determine the exact location of the plume or to predict when and where the plume could reach a surface expression point in Cane Valley Wash. Based on the current understanding of groundwater conditions, flow rate, and flow direction, the plume of impacted ground water has not reached a surface discharge point. Therefore, it is assumed there is no current site-related groundwater risk to the aquatic life in Cane Valley Wash or to terrestrial animals that may gain access to the wash. 
Based on the location of the frog ponds and the direction of groundwater flow, it is unlikely that site-related groundwater has or will discharge to these frog ponds (see Figure 2.7). These ponds are cross gradient to the site and are fed by a spring and seeps. The source of this spring and seep water is probably the unconsolidated aquifer from the east and south; therefore, this water source is probably not affected by former activities at the site. The water quality has been monitored for several years in two of these ponds (sampling locations 621 and 622) and will be discussed in Section 7.2. Based on the water quality data for these ponds, no evidence suggests these ponds have been contaminated by site activities.

A potential current pathway involves plant uptake of contaminants in groundwater. Because of the shallow depth to groundwater lapproximately 10 $\mathrm{ft}(3 \mathrm{~m})$ or less below land surface) the possibility exists that some plants could access contaminated groundwater either currently or in the future as the plume moves downgradient. Plant uptake is evaluated in this risk assessment, assuming the plant roots accessed groundwater containing the 95 percent $\mathrm{UCL}$ of the median concentrations for the contaminants elevated above background listed in column 1 of Table 3.4. Because ecological effects differ from human health effects, the complete list of contaminants will be contaminants of conern used in evaluation of ecological impacts in this chapter.

For the purposes of this baseline risk assessment, the following future hypothetical exposure pathways were evaluated. As mentioned previously, the local population uses the Cane Valley Wash floodplain, including land downgradient of the tailings piles, to graze livestock (sheep, cattle, horses, and goats). At some point in the future, a well could be placed in the plume and contaminated groundwater used as a water supply for a livestock watering pond (which could be stocked with fish) or for irrigation of agricultural crops.

\subsection{ECOLOGICAL RECEPTORS}

A description of the ecological receptors present at or in the vicinity of the Monument Valley UMTRA site is based on information compiled in previous DOE reports (DOE, 1989; 1993). No recent ecological field surveys have been conducted.

The dominant plant species observed in the desert shrub habitat adjacent to the tailings piles are greasewood, shadscale, broom snakeweed, and soapweed. These species (plus black brush, cliffrose, small Utah juniper, and singleleaf ash) occupy the rocky terrain south and west of the site. The blow sand areas just west of the tailings pile are dominated by rabbitbrush, vanclevea, and Russian thistle (EES, 1986).

The designated tailings site and adjacent areas (Baucom, 1985) do not include wetlands or riparian habitat las defined by the Fish and Wildlife Service (FWS)] (Cowardin et al., 1979). 
Wildlife use of the highly disturbed areas such as the tailings piles is expected to be minimal. Also, because remediation of the piles is scheduled for completion by 1994 , the tailings will be eliminated as a future exposure route. A total of 19 species of amphibians and reptiles may occur in the site area. Observed species include the side-blotched, western whiptail, leopard, desert spiny, and sagebrush lizards. An estimated 42 species of nesting birds may occur near the site. Seventeen species were observed near the site with the black-throated sparrow and rock wren being the most common. Numerous ducks were observed in the vicinity of the frog ponds. Twenty-six species of mammals may reside near the Monument Valley site; the black-tailed jackrabbit, desert cottontail, and white-tailed antelope squirrel were observed (Burt, 1985; FBD, 1983). Big game species are not known to occur at or near the site.

A list of threatened and endangered species and other species of concern that may occur in the tailings site area was developed through consultation with the FWS and the Navajo Nation (Baucom, 1985; Diswood, 1985; House, 1985; Ruesink, 1985). The consultation process resulted in the identification of 13 species. Nine species of wildlife and four species of plant life were included on this list. It was determined that none of the wildlife species would occur near the site.

Suitable habitat for three of the four plant species (Cutler milkweed, Monument Valley milkvetch, and Eremocrinum alvomarginatum) do occur in the area of the site. However, these species were not observed at or near the Monument Valley site in 1986 (EES, 1986).

As described previously, the water quality of the frog ponds (locations 621 and 622 ) is considered to be representative of background coriditions because the source of water for these ponds is from groundwater and surface water unaffected by the tailings site. However, for this baseline risk assessment, the detected concentrations for the contaminants of concern are compared to available Federal water quality criteria (FWOC) (Table 7.1). These comparison criteria are designed to protect freshwater aquatic life from chronic exposure (EPA, 1986). If no FWOC were available for a particular contaminant, other available comparison values were reported.

A comparison of the historical surface water data from the frog ponds with available water quality criteria indicates that the concentrations of magnesium, manganese, potassium, sodium, vanadium, and uranium exceeded their respective comparison criteria at both locations. It should be noted that none of these metals have promulgated FWOC, and that the values presented in Table 7.1 are advisory values. Although these advisory values are calculated using the same methods used by the EPA to calculate FWOC (Suter et al., 1992), the toxicological data base from which these values were derived is very limited. Therefore, these advisory values may underestimate or overestimate concentrations of ecological concern. 
TablTable 7.1 Comparison of contaminants of concern in frog pond water with available water quality criteria

\begin{tabular}{|c|c|c|c|c|}
\hline \multirow[b]{2}{*}{1} & \multirow[b]{2}{*}{ Contaminant of concern } & \multicolumn{2}{|c|}{ Median concentration in frog pond water } & \multirow[b]{2}{*}{ FWOC } \\
\hline & & Location 621 & Location 622 & \\
\hline Am & Ammonium & 0.1 & 0.1 & NA \\
\hline Cali & Calcium & 41 & 38 & NA \\
\hline Chl & Chloride & 11 & 27 & $230^{a}$ \\
\hline Iror & Iron & 0.07 & 0.05 & 1.0 \\
\hline Ma! & Magnesium & 31 & 66 & $0.00016^{b}$ \\
\hline Mat & Manganese & 0.05 & 0.03 & $0.011^{b}$ \\
\hline Nitr & Nitrate & 1.0 & 3.7 & $90^{\mathrm{C}}$ \\
\hline Pho & Phosphate & 0.1 & 0.2 & NA \\
\hline Pot & Potassium & 4.4 & 11 & $0.00013^{b}$ \\
\hline Silis & Silica & 8.2 & 15 & NA \\
\hline Soc & Sodium & 47 & 390 & $0.48^{b}$ \\
\hline Stro & Strontium & 0.42 & 0.40 & NA \\
\hline & Sulfate & 54 & 400 & NA \\
\hline Ura & Uranium & 0.018 & 0.0052 & $0.000007^{b}$ \\
\hline Van & Vanadium & 0.015 & 0.018 & $0.003^{b}$ \\
\hline $\operatorname{Zin}$ & Zinc & 0.005 & 0.034 & $0.25^{d}$ \\
\hline
\end{tabular}

${ }^{a}$ Frl a From EPA (1992c).

${ }^{b} \mathrm{Nd}{ }^{b_{N o}}$ FWOC available. Value presented is the chronic advisory value (Suter et al., 1992).

${ }^{\mathrm{C}} \mathrm{Ca}{ }^{\mathrm{C}}$ Concentration at or below which no adverse effects are expected for warm water fish

(E) (EPA, 1986).

${ }^{W}$ W Water hardness-related chronic FWQC (EPA, 1986).

No Note: All concentrations reported in $\mathrm{mg} / \mathrm{L}$.

FW FWOC for the protection of freshwater aquatic life from chronic exposure (EPA, 1986), unless

sp/ specified otherwise.

NA NA - Not available. 
Several of the metals listed in Table 7.1 are common constituents of surface water (magnesium, manganese, potassium, and sodium) and are essential micronutrients. The calculated advisory values presented for these four metals are probably well below levels that would actually result in adverse effects to aquatic organisms. For example, naturally occurring concentrations of magnesium in surface waters in the United States range from $8.5 \mathrm{mg} / \mathrm{L}$ to $137 \mathrm{mg} / \mathrm{L}$ (NAS, 1974), whereas the advisory value for magnesium is $0.00016 \mathrm{mg} / \mathrm{L}$. This level is more than four orders of magnitude less than the lower end of the magnesium concentration range $(8.5 \mathrm{mg} / \mathrm{L})$. The concentration range for surface waters representative of the United States is $0.1 \mathrm{mg} / \mathrm{L}$ to $1 \mathrm{mg} / \mathrm{L}, 0.06 \mathrm{mg} / \mathrm{L}$ to $370 \mathrm{mg} / \mathrm{L}$, and $0.2 \mathrm{mg} / \mathrm{L}$ to $7500 \mathrm{mg} / \mathrm{L}$, for manganese, potassium, and sodium, respectively (NAS, 1974). These surface water concentrations were obtained from the STORET data base (NAS, 1974). No comparison water quality criteria were available for the remaining contaminants of concern. However, this water represents background water quality and not mill- or tailings-related contamination. Therefore, it is unlikely the detected concentrations represent an ecological concern.

\subsection{POTENTIAL IMPACT ON WILDLIFE AND PLANTS}

Currently, no exposure pathways are identified as complete at the tailings site. Based on available groundwater data, it is postulated that affected groundwater has not reached a surface discharge point (e.g., Cane Valley Wash).

A potential exposure pathway that was evaluated involves terrestrial vegetation. Terrestrial vegetation can be directly exposed to contaminants in groundwater through uptake by the roots. Contaminants may accumulate in various plant parts and exert a wide range of influences, depending on the contaminant. Plant uptake rates vary greatly among species and are affected by factors such as soil characteristics (e.g., pH, moisture, redox potential, organic matter, plant sensitivity, input-output balance, and cumulative effects). Foraging wildlife can be exposed to contaminants in groundwater by ingesting plants that have bioconcentrated certain contaminants.

No evidence indicates that plant uptake of contaminants in groundwater is occurring at the Monument Valley UMTRA site. However, based on the shallow depth to contaminated groundwater at the site (approximately $10 \mathrm{ft}$ below land surface or less), it is possible the rooting zones of some plants could intercept contaminated groundwater. The rooting depths for some of the types of plants occurring in this area (i.e., desert shrub community) reportedly reach maximum depths of approximately $30 \mathrm{ft}$ below land surface in the vicinity of Los Alamos, New Mexico (Foxx and Tierney, 1986). Although no site-specific data exist for rooting depths, plant uptake of contaminants in groundwater may represent a complete exposure pathway at the site.

Concentrations of the contaminants of concern in plant tissue are estimated using soil-to-plant bioconcentration factors. No soil data or water-to-plant bioconcentration factors are available for this site. However, because plant root 
uptake requires that water and nutrients are in aqueous form, it is considered appropriate to use the soil-to-plant bioconcentration factors for estimating potential plant uptake at the site. The methodology and parameters used to estimate root uptake and plant tissue concentrations for the contaminants of concern are presented in Table 7.2. This methodology is described in detail elsewhere (ORNL, 1984) and therefore will not be presented here.

The estimated plant tissue concentrations for contaminants of concern in the vegetative portions (e.g., stems, leaves) and in the nonvegetative portions (e.g., fruits, tubers) were compared to approximate concentrations (in mature leaf tissue) that are reportedly toxic to plants (phytotoxic) (Table 7.2). As illustrated in Table 7.2, few available data relate tissue concentrations to phytotoxicity. It should be noted that the reported phytotoxic concentrations are not representative of very sensitive or highly tolerant plant species. The estimated contaminant of concern tissue concentrations do not exceed the available phytotoxicity data. However, no comparison data were available for calcium, chloride, iron, magnesium, nitrate, potassium, strontium, sodium, sulfate, and uranium. Therefore, it is not possible to determine if the estimated tissue concentrations could result in adverse effects to plants.

Bioaccumuiation in terrestrial organisms as a contaminant of concern function in ingested plants is a potential exposure pathway at the site. Birds and other vertebrates consuming these plants can bioaccumulate some contaminants of concern in their diet if the amount ingested exceeds the amount eliminated. This is often a function of the areal extent of contamination versus the areal extent of the animals' feeding range. When the contaminated areas are small, the amount of food in the animals' diet usually exceeds the amount of contaminated food and bioaccumulation is not a concern. Therefore, exposure through diet for all trophic level species is possible in certain areas, but the potential for bioaccumulation is not always of concern.

Biomagnification is a more severe situation in which the concentration of a constituent increases in higher levels of the food chain because contaminant concentrations are accumulated through each successive trophic level. Of particular concern for biomagnification effects are the top predators, especially the carnivorous birds and mammals. Only a limited number of constituents have the potential to magnify in the food chain, because most constituents are metabolized and eliminated at each level of the food chain. Historically, the constituents of greatest biomagnification concern have been the organochlorine pesticides, mercury, polychlorinated biphenyls, and dioxins. None of these constituents were detected in media at the site, and based on available information, the potential for the detected contaminants of concern to represent a concern through food chain transfer is probably low. However, no sampling of plant or animal tissue has been conducted to date as part of the site characterization, and it is not possible to definitively determine the bioaccumulation or biomagnification of site-related contaminants of concern. 


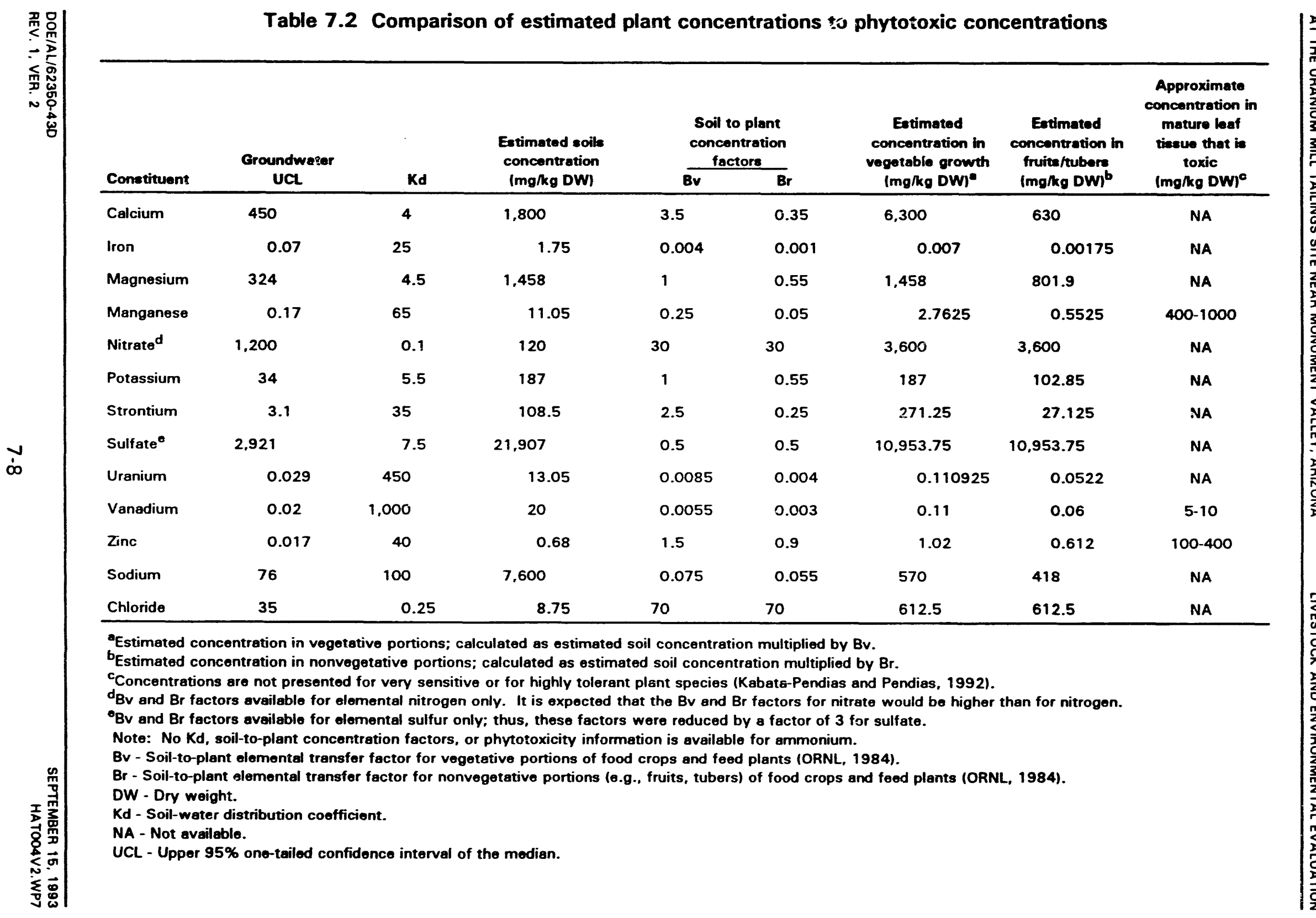


To evaluate the future hypothetical impact on wildife of using contaminated groundwater in a livestock pond (i.e., to animals drinking from the pond or fish stocked in the pond), the 95 percent UCL groundwater contaminant of concern concentrations were compared to available comparison water quality criteria (Table 7.3). No available Federal (or state) criteria or standards protect terrestrial wildlife from exposure to contaminated water. Available surface water quality criteria to protect freshwater aquatic life include the FW/OC IEPA, 1986).

The 95-percent UCL groundwater concentrations for magnesiurn, manganese, nitrate, potassium, sodium, uranium, and vanadium exceed the comparison water quality criteria (Table 7.3), while the groundwater concentrations for chloride, iron, and zinc are below the comparison criteria. However, as discussed previously, several of the comparison criteria are not FWOC but are advisory values. Thus, it should not be construed that adverse effects will occur if an advisory value is exceeded. No comparison water quality criteria are available for ammonium, calcium, phosphate, silica, strontium, or sulfate.

Another future hypothetical use of groundwater in the area is irrigating agricultural crops. Table 7.3 compares the approximate concrntrations in irrigation water to criteria designed to protect plants (EPA, 1972). Four contaminants of concern (iron, manganese, vanadium, and zinc) have comparison uriteria. The 95-percent UCL groundwater concentrations for these four contaminants of concern are below the comparison criteria (Table 7.3). No comparis on criteria are available for the remainder of the contaminants of concern. Therefore, it is not possible to evaluate the potential of these compoundis to adversely affect plants through irrigation water. The available information suggests that using groundwater as irrigation water would not result in deleterious effects to plants.

\subsection{POTENTIAL IMPACT TO LIVESTOCK}

Impacted groundwater originating from the former processing site is not believed to have reached a surface exposure point (i.e., Cane Valley Wash). Thus, no site-related risk occurs to livestock currently drinking water in the area downgradient of the former processing site. Livestock have been observed grazing on vegetation growing in the Cane Valley Wash floodplain. Ingestion by livestock of vegetation that may have bioconcentrated contaminants from groundwater is a potential pathway. However, without additional data (e.g., actual plant tissue concentrations) it is difficult to evaluate this exposure pathway.

Based on past and current agricultural activities in the area surrounding the site, the possibility exists that, at some point in the future, groundwater could be used in a livestock watering pond. In an attempt to evaluate the potential impact to livestock in this hypothetical scenario, the 95-percent UCL groundwater contaminant of concern concentrations are compared in Table 7.3 to approximate drinking water concentrations considered protective of livestock 
Table 7.3 Comparison of contaminants of concern in groundwater with available water quality criteria

\begin{tabular}{|c|c|c|c|c|}
\hline $\begin{array}{l}\text { Contaminant of } \\
\text { concern }\end{array}$ & Groundwater UCL & FWOC* & $\begin{array}{c}\text { Water } \\
\text { concentration } \\
\text { protective of } \\
\text { livestock }^{\text {b }}\end{array}$ & $\begin{array}{l}\text { Concentration in } \\
\text { Wrigation water } \\
\text { protective of plants }\end{array}$ \\
\hline Ammonium & 366 & NA & NA & NA \\
\hline Calcium & 450 & NA & NA & NA \\
\hline Chloride & 35 & $230^{\circ}$ & NA & NA \\
\hline Iron & 0.07 & 1 & NA & 5.0 \\
\hline Magnesium & 324 & $0.00016^{d}$ & NA & NA \\
\hline Manganese & 0.17 & $0.011^{d}$ & NA & 0.20 \\
\hline Nitrate & 1200 & $90^{\circ}$ & 100 & NA \\
\hline Phosphate & 0.6 & NA & NA & NA \\
\hline Potassium & 34 & $0.00013^{d}$ & NA & NA \\
\hline Silica & 23 & NA & NA & NA \\
\hline Sodium & 76 & $0.48^{d}$ & INA & NA \\
\hline Strontium & 3.1 & NA & NA & NA \\
\hline Sulfate & 2921 & NA & 1000 & NA \\
\hline Uranium & 0.029 & $0.000007^{d}$ & NA & NA \\
\hline Vanadium & 0.02 & $0.003^{d}$ & 0.1 & 0.10 \\
\hline Zinc & 0.017 & $1.5^{f}$ & 25 & 2.0 \\
\hline
\end{tabular}

${ }^{\text {a } F W O C ~ u n l e s s ~ s p e c i f i e d ~ o t h e r w i s e . ~}$

${ }^{b}$ From EPA (1972) unless specified otherwise. Values shown are for water used continuously on all soils. cFrom EPA (1992c).



${ }^{\circ}$ Concentration at or below which no adverse effects are expected for warm water fish (EPA, 1986).

'Water hardness-related chronic FWOC (EPA, 1986). Criterion presented was calculated using the average hardness $(2340 \mathrm{mg} / \mathrm{L})$ determined from concentrations of calcium and magnesium in alluvial aquifer wells. UCL - The upper $95 \%$ one-tailed confidence interval of the median.

NA - Not available.

Note: All concentrations reported in $\mathrm{mg} / \mathrm{L}$. 
(EPA, 1972). The 95-percent UCL groundwater concentrations exceed the comparison water quality criteria for nitrate and sulfate while the 95-percent UCL concentrations for vanadium $(0.02 \mathrm{mg} / \mathrm{L})$ and zinc $(0.017 \mathrm{mg} / \mathrm{L})$ are below the comparison criteria $(0.1 \mathrm{mg} / \mathrm{L}$ and $25 \mathrm{mg} / \mathrm{L}$, respectively). The groundwater concentration of nitrate $(1200 \mathrm{mg} / \mathrm{L})$ is more than one order of magnitude above the comparison criteria $(100 \mathrm{mg} / \mathrm{L})$. If this groundwater were the sole source of drinking water for livestock, it would ultimately result in death to the ruminants (e.g., cattle) from methemoglobinemia (Deeb and Sloan, 1975; NAS, 1972). No comparison water quality criteria have been reported for the remainder of the contaminants of concern. However, the available information suggests that using groundwater containing the 95-percent UCL contaminant of concern concentrations as a source of drinking water for livestock would be unacceptable, due to nitrate and sulfate concentrations.

\subsection{SUMMARY}

Insufficient water quality criteria are available to allow comprehensive evaluation of the effect of contaminated groundwater on livestock and the environment. However, available criteria suggest no ecological threat exists to plants, either irrigated, or having roots in contact, with the most contaminated water in the unconsolidated aquifer. Water from the most contaminated wells in this aquifer would exceed available water quality criteria protective of aquatic life for magnesium, manganese, nitrate, potassium, sodium, uranium, and vanadium. However, there are not enough data to adequately evaluate whether exposure to this groundwater would actually result in adverse effects to aquatic life. In the unconsolidated aquifer, watering livestock from the most contaminated wells would be unacceptable because of elevated nitrate and sulfate concentrations.

Consumption of plants that may have bioconcentrated certain contaminants from groundwater is a potential exposure pathway to wildlife and domestic livestock. However, without additional data (e.g., tissue analysis, plant consumptiun rates, frequency and duration of exposure), it is difficult to evaluate whether this pathway represents an ecological hazard.

Surface water currently used by livestock, although fed by the unconsolidated aquifer, is upstream of and not impacted by the contaminant plume. Evaluation of this water verifies that no adverse effects to livestock or vegetation would result from the use of the water in the frog ponds.

As discussed in Sections 2.3.3 and 2.3.4, the potential exists for contaminated groundwater to be expressed on the surface in Cane Valley Wash downstream (north) of the frog ponds. Currently, this surface water is being sampled to ensure no contaminants have reached this area. Concentrations of contaminants that might reach the surface would be expected to be considerably lower (because of dispersion and dilution) than the UCL concentrations on which this ecological assessment was based; therefore, use of this water would present proportionally less hazard. Monitoring upstream of the point of expression could verify that no hazard exists. 


\subsection{INTERPRETATION AND RECOMMENDATIONS}

\subsection{RISK SUMMARY}

The UMTRA Project is required by the UMTRCA to protect public health and the environment from radiological and nonradiological hazards associated with the uranium mill sites.

This baseline risk assessment was conducted on the Monument Valley site to evaluate the presence of these hazards. Because groundwater is currently not used by area residents, human health is not at risk. However, health risks would be associated with potential future use of contaminated groundwater.

The primary risks associated with ground water contamination at the Monument Valley processing site result from the ingestion of nitrate and sulfate by humans and other animals. Using groundwater from the most contaminated portion of the plume for drinking purposes will result in nitrate intakes in the potentially lethal range for infants, following short-term exposure. These nitrate levels are also unacceptable for domestic livestock and wildlife. Sulfate levels in plume wells are associated with severe diarrhea, which may enhance the toxicity of nitrate in infants.

\subsection{GROUNDWATER CRITERIA}

In 1983, the EPA established health and environmental protection standards for the UMTRA Project, and in 1987 the EPA proposed revised groundwater standards in UMTRCA. The UMTRA Project is required to adhere to the 1987 proposed groundwater standards until final standards are published. The UMTRCA groundwater standards consist of groundwater protection standards to evaluate disposal cell performance and groundwater cleanup standards for existing contamination at processing sites. These standards are summarized in Table 8.1 for contaminants that have a proposed maximum concentration limit (MCL). Because an $M C L$ is not established for every contaminant, the proposed standard requires meeting background levels for those contaminants that do not have an MCL.

While these standards appiy only to the UMTRA Project, the EPA has also published drinking water health advisory levels for both long-term and shortterm exposures. These advisories also are shown in Table 8.1.

Nitrate concentrations in plume wells have consistently exceeded the MCL and health advisory levels. Exceedance of the MCL for uranium has occurred only in well 657, though it is not clear if these uranium levels are related to the mill activities or subsurface ore bodies. Selenium marginally exceeded the $\mathrm{MCL}$ in a 1989 sampling of plume wells; however, the concentrations of selenium are not statistically above background. 
Table 8.1 Concentration limits of constituents

\begin{tabular}{|c|c|c|c|}
\hline Constituent & $\begin{array}{c}\text { UMTRCA MCL } \\
40 \text { CFR } 192.02 \\
\text { (mg/L) }\end{array}$ & $\begin{array}{l}\text { Health advisories } \\
\text { 10-kg child, 10-day } \\
\text { (mg/L) }\end{array}$ & $\begin{array}{l}\text { Health advisories } \\
\text { 70-kg adult lifetime } \\
\text { (mg/L) }\end{array}$ \\
\hline \multicolumn{4}{|l|}{ Chemicals (inorganic) } \\
\hline Antimony & - & 0.015 & 0.003 \\
\hline Arsenic & 0.05 & - & - \\
\hline Barium & 1.0 & - & 2 \\
\hline Boron & - & 0.9 & 0.6 \\
\hline Cadmium & 0.01 & 0.04 & 0.005 \\
\hline Chromium & 0.05 & 1.0 & 0.1 \\
\hline Copper & - & - & - \\
\hline Fluoride & - & - & - \\
\hline Lead & 0.05 & - & $0.015^{a}$ \\
\hline Manganese & - & - & - \\
\hline Mercury & 0.002 & - & - \\
\hline Molybdenum & $0.1^{b}$ & 0.08 & 0.04 \\
\hline Nickel & - & 1.0 & 0.1 \\
\hline Nitrate & $44^{c, d}$ & $44^{d, e}$ & - \\
\hline Selanium & $0.01^{c}$ & - & - \\
\hline Silver & 0.05 & 0.2 & 0.1 \\
\hline Strontium & - & 25.0 & 17 \\
\hline Sulfate & - & - & - \\
\hline Thallium & - & 0.007 & 0.0004 \\
\hline Vanadium & - & 0.08 & 0.02 \\
\hline Zinc & - & 6.0 & 2 \\
\hline \multicolumn{4}{|l|}{ Radionuclides } \\
\hline Radium-226/-228 & $5 \mathrm{pCi} / \mathrm{L}$ & - & - \\
\hline $\begin{array}{l}\text { Uranium } \\
\text { (U-234/-238) }\end{array}$ & $\begin{array}{c}30 \mathrm{pCi} / /^{\mathrm{c}, f} \\
10.044 \mathrm{mg} / \mathrm{L})\end{array}$ & - & - \\
\hline
\end{tabular}

Aaction level.

bexceeded in background and plume wells in unconsolidated aquifer.

CExceeded in plume wells.

Equal $10 \mathrm{mg} / \mathrm{h}$ nitrate as nitrogen.

Under review.

'Exceeded in DeChelly 657. 


\subsection{RISK MITIGATION MEASURES}

Because there is a potential for serious health effects following short-term use of nitrate-contaminated groundwater, this section presents possible ways to restrict access to groundwater so as to mitigate risks.

Institutional controls are defined in the proposed groundwater standards for UMTRA as mechanisms that can be effectively used to protect human health and the environment by controlling access to contaminated groundwater. Although the proposed standards refer to institutional controls for long periods of time (e.g., up to 100 years during natural flushing), this concept can also be applied to short-term or interim restriction of access to groundwater. Because it will take years to characterize groundwater at the Monument Valley site and because not all 24 UMTRA sites can be evaluated simultaneously, interim institutional controls are needed before remedial action decisions are made for individual sites.

Successful institutional controls can be implemented by permanent government entities. The Division of Natural Resources manages water resources within the Navajo Nation. Both the Division of Natural Resources of the Navajo Nation and the Navajo Nation Environmental Protection Agency are responsible for water supply, standards, and discharge. The Division of Natural Resources is responsible for administering the water permit system and developing water code compliance regulations for the Navajo Nation.

Currently, two permitting categories exist for water access: permits for well drilling and permits for water use. Both permits are necessary for drilling new wells. Permits usually undergo an administrative and a technical review. Agency implementation of institutional controls would be most effective at the technical review level. Tribal agencies and local authorities would have to agree to the technical criteria for implementing institutional control of groundwater use.

After obtaining signature approval from the director of Water Resource Management, a permit is sent to the Navajo Department of Justice to determine any jurisdictional issues or problems with water rights. The permit is then reviewed by the Executive Director of the Division of Natural Resources to determine the potential for regional, political, or social concerns or impacts.

Establishing interim institutional controls and ensuring the protection of human health and the environment would require a consensus among Navajo Nation governmental agencies and local Navajo governing authorities and chapter houses. Local authorities would probrably have to be responsible for monitoring new wells to ensure that they have been approved. The governing authorities would also need to be informed of monitoring results and the anticipated duration of contamination problems. Chapter houses would probably be the most effective organizations for educating local residents about potential risks and the necessity of access restrictions. 
If access is denied, especially to water sources traditionally used in the past, a readily accessible alternative water supply must be provided. An alternative supply would have to be installed with the consultation of the local authorities. Providing an alternate water source for the residents in the vicinity of the Monument Valley site would help mitigate the possibility of accessing contaminated water in the unconsolidated aquifer by hand-digging wells and ponds. Although hand-digging of wells and ponds occurs at this site, it has not occurred in the vicinity of the present location of the contaminant plume. This type of access is difficult to control; however, reducing the residents' need for additional water supplies by providing good alternative water sources may be the most effective control at this site.

\subsection{FUTURE SITE ACTIVITIES}

Surface remediation at Monument Valley should be completed by spring 1994. For the groundwater phase, monitoring groundwater and potential surface expression points will continue until the detailed characterization of the site groundwater is complete.

To resolve outstanding questions with respect to groundwater quality, movement, and surface expression at this site, the following monitoring activities may be necessary:

- Because wells in the unconsolidated aquifer are screened at varying depths and may not provide water level data appropriate to delineate the water table map, installing additional monitor wells/piezometers with screened sections that bracket the water table is recommended to decrease the uncertainties in assessment of the hydraulic gradients and the linear velocities of the uppermost water-bearing zone.

- Measuring the rate of discharge from surface springs in Cane Valley Wash and north of the tailings site at sampling location 620 would allow accurate assessment of the relative contributions of spring water and downstream groundwater seepage to the ephemeral flow in the wash.

- Sampling deeper zone wells (614 and 657) should continue to verify reduction in site-related contaminants resulting from the upward movement of groundwater over time.

\subsection{RECOMMENDATIONS}

In general, the proposed groundwater standards consisting of MCLs or bac. ground concentrations are sufficient to protect human health and the environment. However, in some cases, a risk assessment may identify site-specific factors that suggest these standards may either be too restrictive or not restrictive enough. When standards are too restrictive, there may be no potential for exposure, and a less restrictive alternate concentration limit (ACL) may be sought. In other cases, the standards may not be sufficiently protective (e.g., if many contaminants are near the MCL with additive or synergistic adverse health effects). 
At Monument Valley, no permanent physical barrier prevents access to contaminated groundwater at the former processing site. Therefore, ACLs could not be justified for those constituents with MCLs. However, for those constituents that exceed background and do not have MCLs, this assessment suggests that background levels are more restrictive than necessary. This includes contaminants screened because their concentrations fall within nutritional levels (e.g., iron, zinc). It also includes other contaminants such as strontium and vanadium that were demonstrated to be at concentrations well below adverse health effect levels. ACLs should be sought for these contaminants.

The nitrate MCL of $44 \mathrm{mg} / \mathrm{L}$ (10 $\mathrm{mg} / \mathrm{L}$ as nitrogen) may not be sufficiently protective for infants where sulfate concentrations are also high. Further study of this potential synergism is needed before remedial action decisions are made for this site.

The levels of nitrate present a serious health risk if contaminated groundwater at this site is used. The levels in monitor wells 606 and 655, as well as in other monitor wells within the contaminant plume in the unconsolidated aquifer, substantially exceed levels at which fatal cases of methemoglobinemia have been reported for infants in the literature. This situation requires implementation of institutional controls as soon as possible, regardless of the remedial action strategy pursued. In view of this situation, development of the DeChelly water resource for use by the valley residents is recommended. This could be accomplished simply by improving access to artesian wells 625 and 613 , which are currently used by the residents.

In the near term, it is recommended that wells continue to be monitored for ammonium and the contaminants of concern listed in column 4 of Table 3.4. Though ammonium is not considered to pose a health threat, the elevated levels are likely to affect the taste and odor of the water, thereby decreasing its usefulness to the residents. Although not all the constituents in column 4 present health risks, the pattern of elevation in these constituents is useful in evaluating the impact of water from the unconsolidated aquifer on downgradient wells and deeper water-bearing zones. More extensive sampling of background wells in the deeper zones is also needed to better evaluate water quality in these zones and to verify that the rate of upward flow from the DeChelly Sandstone is sufficient to reduce site-related contaminants.

If site monitoring indicates the contaminant plume has reached Cane Valley, sampling of plant and animal tissues is recommended to assess bioaccumulation and the potential for food chain transfer. 


\subsection{LIST OF CONTRIBUTORS}

The following individuals contributed to the preparation of this report.

\begin{tabular}{ll}
\hline Name & Contribution \\
\hline J. Lewis & $\begin{array}{l}\text { Overall document responsibility; authorship, } \\
\text { toxicology } \\
\text { Geochemistry }\end{array}$ \\
A. Meijer & Hydrology \\
R. Papusch & Hydrogeology \\
D. Tarbox & Statistical evaluation \\
K. Smith & Ecological assessment \\
C. Day & Technical review, toxicology \\
L. Flowers & Institutional controls \\
R. Neri-Zagal & Word processing \\
L. Keith, C. Slosberg & Graphic design \\
E. Bond, J. Brannan, B. Harvey & Technical editing and document production \\
J. Torline & coordination \\
\hline
\end{tabular}




\subsection{REFERENCES}

Aiyar, A. S., and A. Sreenivasan, 1961. Proc. Soc. Exp. Biol. Med., Vol. 107, pp. $914-916$.

Ballou et al. (J. E. Ballou, R. A. Gies, A. C. Case, D. L. Haggard, R. L. Buschbom, and J. L. Ryan), 1986. "Deposition and Early Disposition of Inhaled Uranium-233 Uranyl Nitrate and Uranium-232 Uranyl Nitrate in the Rat," Health Physics, Vol. 51, pp. 755-772.

Baucom, F., 1985. Fish and Wildlife Service, Ecological Services, Phoenix, Arizona, personal communication to David Lechel, Environmental Services, Jacobs Engineering Group Inc., Albuquerque, New Mexico, August 19, 1985.

Belehova, B. A., 1969. Scientific Transactions of the Irkutsk State Medical Institute, Vol. 96, pp. $20-23$ (in Russian).

Berlin, M., and B. Rudell, 1986. "Uranium," Handbook on the Toxicology of Metals, Vol. II, second edition, L. Friberg, G. F. Nordberg, and V. B. Vouk, eds., pp. 647-658, Elsevier Science Publishers, New York, New York.

Bolyai et al. (J. Z. Bolyai, R. P. Smith, and C. T. Gray), 1972. "Ascorbic Acid and Chemically Induced Methemoglobinemias," Toxicological Applied Pharmacology, Vol. 21. pp. 176-185.

Burt, C. J., 1985. "Unpublished Field Investigation, Mexican Hat, Utah, and Monument Valley, Arizona, Uranium Mill Tailings Sites," PDC Nos. 9.15.0 and 19.15.0, prepared by the Technical Assistance Contractor (Jacobs-Weston Team), Albuquerque, New Mexico, for the U.S. Department of Energy, UMTRA Project Office, Albuquerque Operations Office, Albuquerque, New Mexico.

Byerrum et al. (R. U. Byerrum, R. E. Eckardt, L. L. Hopkins), 1974. Vanadium, National Academy of Sciences, Washington, D.C.

Byrne, A. R., and L. Kosta, 1978. Sci. Total Environ., Vol. 10, pp. 17-30.

Comar, C. L., and R. H. Wasserman, 1964. "Strontium," Mineral Metabolism, C. L. Comar and F. Bronner, eds., Vol. II, Part A, pp. 523-572, Academic Press, New York and London.

Cothern, C. R., and W. L. Lappenbusch, 1983. "Occurrence of Uranium in Drinking Water in the U.S.," Health Physics, Vol. 45, pp. 89-99.

Cowardin et al. (L. M. Cowardin, V. Carter, F. C. Golet, and E. T. LaRoe), 1979. "Classification of Wetlands and Deepwater Habitats of the United States," FWS/OBS-79/31, Office of Biological Services, Fish and Wildlife Service, Washington, D.C. 
Curran et al. (G. L. Curran, D. L. Azarnoff, and R. E. Bolinger), 1959. Journal of Clinical Investigation, Vol. 38, pp. 1251-1261.

Curzon, M. E. J., 1985. "The Relation Between Caries Prevalence and Strontium Concentrations in Drinking Water, Plaque, and Surface Enamel," Journal of Dental Research, Vol. 64(12), pp. 1386-1388.

DOE (U.S. Department of Energy), n.d. "Programmatic Environmental Impact Statement for Groundwater Contamination at the UMTRA Sites," in preparation, DOE IJMTRA Project Office, Albuquerque Operations Office, Albuquerque, New Mexico.

DOE (U.S. Department of Energy), 1993. Remedial Action Plan for the Codisposal and Stabilization of the Monument Valley and Mexican Hat Uranium Mill Tailings at Mexican Hat, Utah, final, UMTRA-DOE/AL 050509.0000, DOE UMTRA Project Office, Albuquerque Operations Office, Albuquerque, New Mexico.

DOE (U.S. Department of Energy), 1989. Environmental Assessment of Remedial Action at the Monument Valley Uranium Mill Tailings Site, Monument Valley, Arizona, final, UMTRA-DOE/AL 0368, DOE UMTRA Project Office, Albuquerque Operations Office, Albuquerque, New Mexico.

Deeb, B. S., and K. W. Sloan, 1975. Nitrates, Nitrites, and Health, University of Illinois Colleges of Agriculture and Veterinary Medicine, Agricultural Experiment Station, Bull. 750.

Dimond et al. (E. G. Dimond, J. Caravaca, and A. Benchimoll, 1963. "Vanadium: Excretion, Toxicity, Lipid Effect in Man," American Journal of Clinical Nutrition. Vol. 12, pp. 49-53.

Diswood, S., 1985. Navajo Fish and Wildlife Department, Navajo Nation, Window Rock, Arizona, personal communication to Charles Burt, Environmental Services, Jacobs Engineering Group Inc., Albuquerque, New Mexico, August 27, 1985.

EES (Ecosphere Environmental Services), 1986. "A Threatened-Endangered Plant Species Survey for Two Uranium Tailings Piles-Monument Valley Site, Monument Valley, Apache County, Arizona," prepared for Jacobs Engineering Group Inc., Albuquerque, New Mexico, by EES, Farmington, New Mexico.

EPA (U.S. Environmental Protection Agency), 1993. Integrated Risk Information System (IRIS), data base, Dffice of Research and Development, Washington, D.C.

EPA (U.S. Environmental Protection Agency), 1992a. Final Drinking Water Criteria Document for Sulfate, Health and Environmental Criteria Division, Office of Science and Technology, Washington, D.C.

EPA (U.S. Environmental Protection Agency), 1992b. Health Effects Assessment Summary Tables, EPA/OERR 920.6-303(92-1), Office of Research and Development, Office of Emergency and Remedial Response, Washington, D.C. 
EPA (U.S. Environmental Protection Agency), 1992c. Toxic Substance Spreadsheet, Region IV, Atlanta, Georgia.

EPA (U.S. Environmental Protection Agency), 1990. Drinking Water Criteria Document for Stable Strontium, prepared by the Office of Health and Environmental Assessment, Environmental Criteria and Assessment Office, Cincinnati, Ohio, for the Office of Drinking Water, Washington, D.C.

EPA (U.S. Environmental Protection Agency), 1989. Risk Assessment Guidance for Superfund, Volume II, Environmental Evaluation Manual, EPA/504/1-89/001, Office of Emergency and Remedial Response, Washington, D.C.

EPA (U.S. Environmental Protection Agency), 1986. Quality Criteria for Water, EPA 440/5-86-001, Office of Regulations and Standards, Washington, D.C.

EPA (U.S. Environmental Protection Agency), 1977. Scientific and Technical Assessment Report on Vanadium, EPA-600-6-77-002, U.S. Environmental Protection Agency, Washington, D.C.

EPA (U.S. Environmental Protection Agency), 1972. Water Quality Criteria, National Academy of Sciences and National Academy of Engineering, Washington, D.C.

FBD (Ford, Bacon, \& Davis, Inc.), 1983. Environmental Assessment of Remedial Actions on the Uranium Mill Tailings at the Monument Valley Site, Monument Valley, Arizona, UMTRA-SNL//4 4244, unpublished preliminary draft prepared for the U.S. Department of Energy, UMTRA Project Office, Albuquerque Operations Office, Albuquerque, New Mexico.

Fisenne et al. (I. M. Fisenne, P. M. Perry, and N. H. Harley), 1988. "Uranium in Humans," Rad. Prot. Dosim., Vol. 24, pp. 127-131.

Foxx, T. S., and G. D. Tierney, 1986. "Rooting Patterns in the Pinyon-Juniper Woodland," submitted at the Pinyon-Juniper Symposium, Reno, Nevada, January 12-18, 1986, Los Alamos National Laboratory, LA-UR--85-3819, DE86 002433.

Friberg et al. (L. Friberg, G. F. Nordberg, and V. B. Vouk), 1986. Handbook on the Toxicology of Metals, Volume II: Specific Metals, second edition, Elsevier, New York, New York.

Gosselin et al. (R. E. Gosselin, H. C. Hodge, and R. P. Smith), 1976. Clinical roxicology of Commercial Products, fourth edition, Williams and Wilkins, Baltimore, Maryland.

Hadjimarkos, D. M., 1968. Adv. Oral Biol., Vol. 3, pp. 253-292.

Hadjimarkos, D. M., 1966. Nature, Vol. 209, pp. 1137.

Harris et al. (W. R. Harris, S. B. Friedman, and D. Silberman), 1984. J. Inorg. Biochem., Vol. 20, pp. 157-169. 
House, D., 1985. Navajo Natural Heritage Program, Navajo Nation, Window Rock, Arizona, personal communication to Charles Burt, Environmental Services, Jacobs Engineering Group Inc., Albuquerque, New Mexico, December 13, 1985.

Hoy, W., 1993. Lovelace Medical Foundation, personal communication with J. Lewis, UMTRA Project, Jacobs Engineering Group Inc., Albuquerque, New Mexico, May 26, 1993.

ICRP (International Commission on Radiological Protection), 1960. ICRP Publ., 2.

Israeli, M., and C. B. Nelson, 1992. "Distribution and Expected Time of Residence for U.S. Households," Risk Analysis, Vol. 12, No. 1, pp. 65-72.

Kabata-Pendias, A., and H. Pendias, 1992. Trar:e Elements in Soils and Plants, second edition, CRC Press, Boca Raton, Florida.

Kamm et al. (L. Kamm, G. G. McKeown, and D. M. Smith), 1965. "New Colorimetric Method for the Determination of the Nitrate and Nitrite Content of Baby Foods," J. Assoc. Offic. Agr. Chemists, Vol. 48, p. 892.

Lagerkvist et al. (B. Lagerkvist, G. F. Nordberg, and V. Vouk), 1986. "Vanadium," Handbook on the Toxicology of Metals, second edition, L. Friberg, G. F. Nordberg, and V. Vouk, eds., Elsevier Science Publishers, New York, New York.

Leach et al. (L. J. Leach, R. M. Gelein, B. J. Panner, C. L. Ylie, and C. C. Cox), 1984. "The Acute Toxicity of the Hydrolysis Products of Uranium Hexafluoride (UF6) When Inhaled by the Rat and Guinea Pig," final report, ISS K/SUB-81-9039-3, NTIS DE84011539.

Lee, D. H. K., 1970. "Nitrates, Nitrites, and Methemoglobinemia," Environmental Research, Vol. 3, pp. 484-511.

Marie et al. (P. J. Marie, M. T. Garba, M. Hott, and L. Miravet), 1985. "Effect of Low Doses of Stable Sr on Bone Metabolism in Rats," Miner. Electrolyte Metab., Vol. 11, pp. 5-13.

Maynard, E. A., and H. C. Hodge, 1949. "Study of Toxicity of Various Uranium Compounds When Fed to Experimental Animals," Pharmacology and Toxicology of Uranium Compounds, National Nuclear Energy Services, Div. VI, Vol. 1, pp. 309-376, C. Voegtlin and H. C. Hodge, eds., McGraw Hill, New York, New York.

Moriarty, F., 1988. Ecotoxicology: The Study of Pollutants in Ecosystems, second edition, Academic Presss, New York, New York.

NAS (National Academy of Sciences), 1974. Nutrients and Toxic Substances in Water for Livestock and Poultry, National Research Council, Washington, D.C. 
NAS (National Academy of Sciences), 1972. Accumulation of Nitrate, Committee on Nitrate Accumulation, Agricultural Board, Division of Biology and Agriculture, National Research Council, Washington, D.C.

NCRP (National Council on Radiation Protection and Measurements), 1984. Exposures from the Uranium Series With Emphasis on Radon and its Daughter, NCRP Report No. 77, Bethesda, Maryland.

ORNL (Oak Ridge National Laboratory), 1984. A Review and Analysis of Parameters for Assessing Transport of Environmentally Released Radionuclides Through Agriculture, ORNL-5786, Health and Safety Research Division.

PL 95-604 (Public Law 95-604), 1978. Uranium Mill Tailings Radiation Control Act of 1978, 42 USC 7901, November 8, 1978, 95th Congress of the United States of America, Washington, D.C.

Parkhurst et al. (D. L. Parkhurst, D. C. Thorstenson, and D. N. Plummer), 1980. PHREEQE-A Computer Program for Geochemical Calculations, U.S. Geological Survey, Water Resources Investigation 80-96, National Technical Information Services Report PB81-167-801, Springfield, Virginia.

Pennington, Jean A., and John W. Jones, 1987. "Molybdenum, Nickel, Cobalt, Vanadium, and Strontium in Total Diets," Journal of the American Dietetic Association, Vol. 87, No. 12, December 1987, American Dietetic Association, Division of Nutrition and Division of Contaminants Chemistry, Center for Food Safety and Applied Nutrition, Food and Drug Administration, Washington, D.C.

Perry et al. (H. M. Perry, Jr., S. Teitlebaum, and P. L. Schwartz), 1955. Fed. Proc., Vol. 14, pp. 113-114.

Prister, B. S., 1969. GKIAE Report by Atomizdat, Moscow [Canadian translation AEC/TR/7178 (1970), and USCEAR Rep. A/AC.82/G/L 1298].

Proescher et al. (F. Proescher, H. A. Seil, and A. W. Stillians), 1917. Am. J. Syph., Vol. 1, pp. 347-405.

Roseberry, A. M., and D. E. Burmaster, 1992. "Lognormal Distributions for Water Intake by Children and Adults," Risk Analysis, Vol. 12, No. 1, pp. 99-104.

Roshchin, A. V., 1968. Vanadium and its Compounds, Medicina, Moscow (in Russian).

Ruesink, R., 1985. Fish and Wildlife Service, Endangered Species Office, Salt Lake City, Utah, personal communication to David Lechel, Environmental Services, Jacobs Engineering Group Inc., Albuquerque, New Mexico, September 23, 1985.

Schroeder et al. (H. A. Schroeder, J. J. Balassa, and I. H. Tipton), 1963. Journal of Chronic Diseases, Vol. 16, pp. 1047-1071.

Smith, G. E., 1966. "Causes of Nitrate Accumulation in Plants and Water Supplies," paper to 18th Annual Midwest Fertilizer Conference, Chicago, Illinois. 
Snyder, F., and W. E. Cornatzer, 1958. Nature, Vol. 182, pp. 462.

Snyder et al. (W. S. Snyder, M. J. Cook, E. S. Nasset, L. R. Karhausen, G. P. Howells, and I. H. Tipton), 1975. International Commission on Radiological Protection (ICRP), Report of the Task Group on Reference Man, ICRP Publ. 23, New York, New York.

Somerville, J., and B. Davies, 1962. Am. Health J., Vol. 54, pp. 54-56.

Stevens et al. (D. J. Stevens, R. C. Brough, R. D. Griffin, and E. A. Richardson), 1983. Utah Weather Guide, Society for Applied Climatology, West Jordan, Utah, and Department of Geography, Brigham Young University, Provo, Utah.

Stevens et al. IW. F. Stevens, W. Bruenger, D. R. Atherton, J. M. Smith, and G. N. Taylor), 1980. "The Distribution and Retention of Hexavalent ${ }^{233} \mathrm{U}$ in the Beagle," Radiat. Res., Vol. 83, pp. 109-126.

Storey, E., 1961. "Strontium 'Rickets' Bone Calcium and Strontium Changes," Austral. Ann. Med., Vol. 10, pp. 213-222.

Sullivan et al. (M. F. Sullivan, P. S. Ruemmler, J. L. Ryan, and R. L. Bushhom), 1986. "Influence of Oxidizing or Reducing Agents on Gastrointestinal Absorption of $U$, Pu, Am, Cm, and Pm by Rats," Health Physics, Vol. 50, pp. 223-232.

Summerskill, W. H. J., and E. Wolpert, 1970. "Ammonia Metabolism in the Gut," American Journal of Clinical Nutrition, Vol. 23, pp. 633-639.

Suter et al. (G. W. Suter, G. W., M. A. Futrell, and G. A. Kerchner), 1992. Toxicological Benchmarks for Screening of Potential Contaminants of Concern for Effects on Aquatic Biota on the Oak Ridge Reservation, Oak Ridge, Tennessee, ORNL/ER-139, Environmental Sciences Division, Oak Ridge National Laboratory, Oak Ridge, Tennessee.

Tank, G., and C. A. Storvick, 1960. Journal of Dental Research, Vol. 39, pp. 473-488.

Tipton et al. (1. H. Tipton, P. L. Stewart, and J. Dickson), 1969. Health Physics, Vol. 9, pp. $103-145$.

Tracy et al. (B. L. Tracy, J. M. Quinn, J. Lahey, A. P. Gilman, K. Mancuso, A. P. Yagdinas, and D. C. Villeneuve), 1992. "Absorption and Retention of Uranium from Drinking Water by Rats and Rabbits," Health Physics, Vol. 62, pp. 65-73.

Tracy et al. (B. L. Tracy, F. A. Prantl, and J. M. Quinn), 1983. "Transfer of ${ }^{226} \mathrm{Ra},{ }^{210} \mathrm{~Pb}$, and Uranium from Soil to Garden Produce: Assessment of Risk," Health Physics, Vol. 44, p. 469.

Van Zinderen Bakker and J. F. Jaworski, 1980. Effects of Vanadium in the Canadian Environment, Ottawa, Canada: National Research Council Canada, Associate Committee Scientific Criteria for Environmental Quality. 
Weigel, F., 1983. "Uranium and Uranium Compounds," Kirk-Othmer Encyclopedia of Chemical Technology, Vol. 23, third edition, pp. 502-547, M. Grayson, ed., John Wiley and Sons, New York, New York.

Witkind, I. J., and R. B. Thaden, 1963. "Geology of Uranium-Vanadium Deposits of the Monument Valley Area, Apache and Navajo Counties, Arizona," U.S. Geological Survey Bulletin, No. 1103, U.S. Government Printing Office, Washington, D.C.

Wrenn et al. (M. E. Wrenn, P. W. Durbin, B. Howard, J. Lipsztein, J. Rundo, E. T. Still, and D. L. Willis), 1985. "Metabolism of Ingested $U$ and Ra," Health Physics, Vol. 48, pp. 601-633.

Yakawa, M., and M. Suzuki-Yasumoto, 1980. Arch. Environ. Health, Vol. 35, pp. 36-44.

\section{CODE OF FEDERAL REGULATIONS}

40 CFR 192, "Health and Environmental Protection Standards for Uranium and Thorium Mill Tailings," Code of Federal Regulations, Title 40, Part 192, U.S.

Environmental Protection Agency, Office of the Federal Register, National Archives and Records Administration, Washington, D.C. 



$12 / 8 / 93$



$$
\text { }
$$

